\title{
Giving Knowledge For Free
}

THE EMERGENCE OF OPEN EDUCATIONAL RESOURCES

Centre for Educational Research and Innovation (CERI)

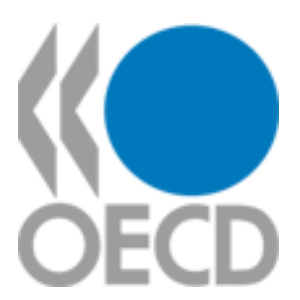

ORGANIZATION FOR ECONOMIC CO-OPERATION AND DEVELOPMENT

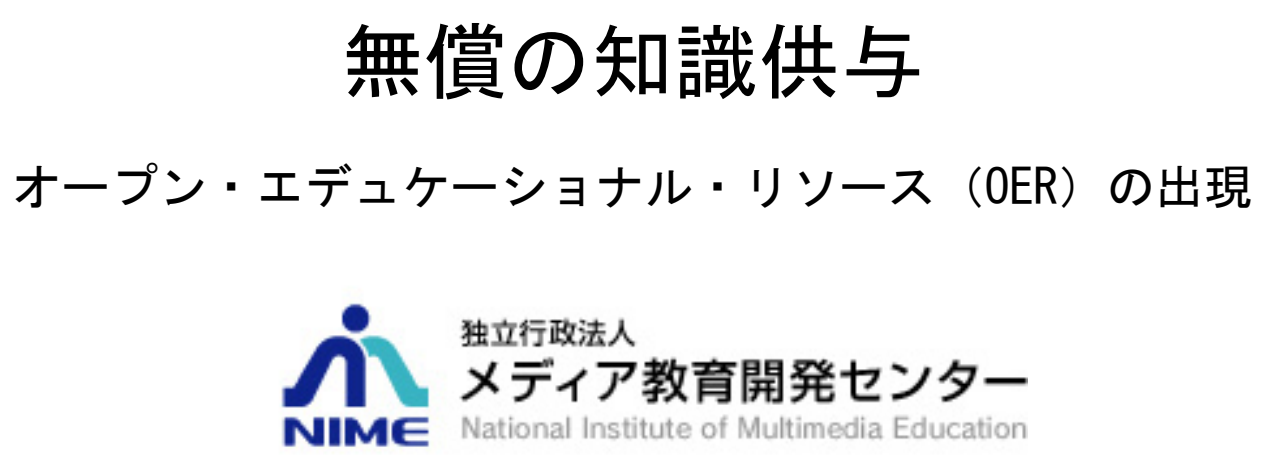




\section{経済協力開発機構 $($ OECD)}

OECDは、民主主義を原則とする30ケ国の先進諸国が集まる唯一の国際機関であり、グロ ーバル化の時代にあって経済、社会、環境の諸問題に取組んでいる。OECDはまた、コーポ レート・ガバナンスや情報経済、高齢化等の新しい課題に先頭になって取組み、各国政府 の新たな状況への対応を支援している。OECDは各国政府がこれまでの政策を相互に比較し、 共通の課題に対する解決策を模索し、優れた実績を明らかにし国内及び国際政策の調和を 実現する場を提供している。

OECD加盟国は、オーストラリア、オーストリア、ベルギー、カナダ、チェコ、デンマー ク、フィンランド、フランス、ドイツ、ギリシャ、ハンガリー、アイスランド、アイルラ ンド、イタリア、日本、韓国、ルクセンブルク、メキシコ、オランダ、ニュージーランド、 ノルウェー、ポーランド、ポルトガル、スロバキア、スペイン、スウェーデン、スイス、 トルコ、英国、米国である。欧州委員会もOECDの活動に参加している。

OECD が収集した統計や、経済、環境、社会の諸問題に関する研究成果は、加盟各国の 合意に基づく条約、指標、原則と同様に OECD 出版物として広く公開されている。

本原書は、以下の英語およびフランス語のタイトルで OECDにより出版されたものである。 Giving Knowledge for Free: The Emergence of Open Educational Resources Les ressources éducatives en libre accès: Pour diffuser gratuitement des connaissances

(C) 2007 OECD

\section{All rights reserved.}

原文英語版から日本語への翻訳は、パリのOECD本部との取り決めによりメディア教育開発 センター（NIME）の責任で行った。その日本語翻訳版の質、原文との整合性等内容につい てはNIMEの責任に帰する。

(C) 2007 National Institute of Multimedia Education (NIME) for this Japanese edition published by arrangement with the OECD, Paris.

本書の日本語翻訳版「無償の知識供与ーオープン・エデュケーショナル・リソース（OER） の出現」の刊行に際し小林登志生および美濃導彦により書かれた序文と前書きは原文英語 版に含まれたものではなく、これらの文中で表明されている意見や主張は必ずしも $\mathrm{OECD} ま$ たはその加盟諸国の公式見解を反映するものではない。 


\title{
NIME研究報告
}

$40-2008$

\section{無償の知識供与 \\ オープン・エデュケーショナル・リソース（OER）の出現 \\ （OECD による OER 最終調查報告書日本語翻訳版）}

小林登志生（監訳）、美濃導彦・川淵明美（翻訳）

\author{
Giving Knowledge For Free \\ The Emergence of Open Educational Resources \\ (Japanese Translation of OER Final Report by OECD)
}

The Translation was prepared by

Toshio Kobayashi, Michihiko Minoh, Akemi Kawafuchi

平成 20 年 3 月

独立行政法人 メディア教育開発センター 


\section{日本語版序文}

本報告書は、OECD が実施した世界主要各国における OER(Open Educational Resources）の動向に関する事例調査結果を英文で 2007 年に刊行した調查報告書を忠実に 日本語に全訳したものである。同 OER プロジェクトには、メディア教育開発センター (NIME) の AIDE (Advancement of International Distance Education) 国際研究プロ ジェクトメンバー (小林・川淵) が、OER プロジェクト主査の Jan Hylén 氏および研究員 の田熊美保女史よりわが国の OER 実情について国内調査するよう協力を要請されて参加し、 AIDE プロジェクト研究活動の一環として、2006 年度にわが国において立ち上がったばか りの JOCW（日本オープンコースウェアー・コンソーシアム）参加諸大学に対する国内調 查を実施した（その調査結果レポートは 2006 年 7 月 OECD およびAIDE のウェッブサイ 卜に掲載、他に海外国際会議等でも発表)。

本企画は、当初は外部出版社による刊行も考慮したが、この種の研究書は一般的にそれ 程読まれるものではないので、むしろその内容が NIMEのミッションにも合致し時宜を得 たものなので、当センターの研究報告書として発行し、全国諸大学・機関および研究者に 配布することにした。OECD 側も本書を日本における e-Learning 推進の中核研究機関と目 される NIME の下で無償で刊行することに大いに意義とメリットがあるとし、本報告書の 発刊に至った。なお、わが国の高等教育機関における OCW の現況については、前述の 2006 年度に実施した JOCW 訪問調査の時点に比べ、参加大学・機関の数、個々のプロジェクト、 公開されているコンテンツ内容など飛躍的に発展しており、また本報告書に記載されてい る他の先進諸外国の OER 実情についても同様に推移していると思われる。OER の今後の 動向については、高等教育以外のレベル、発展途上諸国における潜在的利点などにつきさ らなる調査が期待されるところである。

本文中の人名、固有名詞は原文のままにした。ただし地名・国名はカタカナに変換した。 専門用語等については、同様の表記で統一を図ったが文脈により別訳を余儀なくされた箇 所も多々あり、これら用語の統一に関し不備があれば、それはすべて監訳者の責任である。

本企画の推進にあたっては、OECD 報告書原文の翻訳を、長年の友人である京都大学学 術情報メディアセンターの美濃導彦教授の協力を得て行った。美濃教授には、JOCW 幹事 校および訳者代表として日本語版の前書の執筆もお願いした。ここにあらためて寛大なご 協力に深い感謝の辞を述べる。本翻訳書が、わが国における OER 研究者および OCW 推進 に取り組む関係各位のお役に立てれば幸いである。

最後に、OECD の Jan Hylén 氏（現在は母国スウェーデンに戻り国際コンサルタント） および田熊女史に本件のような有意義なプロジェクトに関与する機会を与えてくださった ことに心より感謝を申し上げる。

2008 年 3 月

メディア教育開発センター教授 小林登志生（監訳者） 


\section{日本語版まえがき}

日本の大規模な総合大学が MIT の働きかけに応じてオープンコースウェア(Open Course Ware: OCW)プロジェクトをはじめたのが、2005 年 5 月である。私も京都大学の担 当者としてこの企画に参画したが、MIT の宮川教授が尾池総長に「人類の知的資産の蓄積 に協力しませんか」とおっしやったのが印象的であった。当時は私も含めてこのような発 想が出来るような環境ではなかったように思う。特に、日本では「公共」という概念がそ れほど重視されないので、このプロジェクトが本当にうまく行くのか、総長にリーダシッ プをとってもらってもどこまで強制力があるのか、が担当者としては心配であった。

そんな中で、学内的には検討チームを立ち上げ、なぜこのようなことをするのかという 議論を進めた。教育情報は人類共通の財産であるので公開す心゙きである、という理念は納 得できるが、総論賛成各論反対という感がどうしてもあり、教材が実際に提供されるかと いう懸念が常に付きまとっている。国内では、慶応大学が中心となって日本オープンコー スウェア連絡会を立ち上げ、大学内の状況を大学間で情報交換しながら外圧で学内を動か すといういかにも日本的な方法でプロジェクトが進んでいった。主要大学のみが参加して いるという状況ではライバル意識から脱落が困難であったこと、慶応大学（特に、福原美 三先生）の献身的なサポートがあったからだと思っている。

2006 年 4 月には、正式に日本オープンコースウェアコンソーシアム (JOCW) を立ち上 げて、活動がなんとか軌道に乗ってきたが、それでも継続性の問題は参加大学の悩みの種 である。それでも、最近は、私立大学も広報活動を意識して参加するようになり、この流 れがようやく安定化してきたように思う。

世界に目を転じると、OCW をきっかけとしてその概念が拡張され、オープンエデュケー ショナルリソース(Open Educational Resources: OER)という形になり、特に国際機関を中 心としてこれを後進国の教育に活用していこうという動きが出てきている。このための最 大の難問は著作権であり、国によってその規定が異なっている。これらの問題に対しても 精力的な取り組みがなされ、クリエイティブ・コモンズという概念も盛んに議論されるよ うになってきた。正直なところ、西洋社会における「公共」の概念の力強さには驚いてい る。

この報告書は世界におけるこのような動きを調査したものであり、「公共」の概念に基づ く大きな流れが読み取れる。日本からの報告は、主に OCW の活動が中心であるが、このレ ポートが、日本における OCW の活動だけでなく、OER の活動の活発化のきっかけとなれ ばと願う次第である。

この企画は長年の友人であるメディア開発教育センターの小林登志生先生から依頼を受 け、最初の翻訳を京都大学大学院情報学研究科知能情報学専攻の大学院生にお手伝をお願 いした。森村吉貴君、中村和晃君、川西康友君、岡田尚基君、八代武大君、Gary Jay Coffman 君に心より感謝する。彼らの協力がなければこの企画はここまで来なかったであろうが、 それでも監訳者の小林先生のお手を大きく煩わしていることは疑いない。重ねて感謝する 次第である。

2008 年 3 月

京都大学学術情報メディアセンター 教授 JOCW 幹事 美濃導彦 


\section{まえがき}

情報社会の発展と情報技術の広範な普及に伴い、新しい学習機会が創出されている。 同時に、「授業や学習がどのように計画・実施されるべきか」という点に関する既存の概念や 実践に意義が投げかけられている。この数年間、高等教育機関では、教育の発展や普及を目 的としてインターネットやその他のデジタル技術が用いられてきた。それにもかかわらず、 つい最近まで、学習教材のほとんどはパスワード等により所有者のシステムの内側に閉ざさ れており、外部の者には手の届かないものとなっていた。オープンエデュケーショナルリソ ース（Open Educational Resources: OER）ムーブメントとは、このような現状を打破し、自由 にコンテンツ（学習教材）を共有できるようにすることを目指すものである。

OECD 教育研究革新センター（Center for Educational Research and Innovation: CERI）では、 “E-learning: The Partnership Challenge”(OECD, 2001)や“E-learning in Tertiary Education-Where do we stand? ” (OECD, 2005)といった報告書を刊行し、既に、高等教育における e-Learning に関する多くの課題に取り組んできた。このうち後者の報告書では、e-Learning は高等教育 において次第に重要視されてきていると結論されている。e-Learning の登録数と提供数は、 当初こそ少なかったものの、明らかに増加傾向を示している。高等教育機関における e-Learning 活動には、形態がオンラインであるのみの頊末なものから、完全にオンラインで 提供される学習プログラムまで、様々なものがある。モジュールは、学部レベルでの学内配 信の補充といったような e-Learning の主要な特色を反映して、e-Learning 活動の大多数を占 めている。

ラーニングオブジェクトは、多くの課題を内包してはいるものの、将来的にはコストを抑え 教育学に革命をもたらし得るような、有望な解決策であると考えられている。これらの課題 のうちのいくつかについては、本レポートにおいて更なる分析を行い、以下の次の 4 つ主 要な疑問について分析する。

・OER 構想のための持続可能な費用／便益モデルをどのように開発するか?

- OER 構想に関連する知的所有権問題とはどのようなものか?

・大学あるいは学部の教員が自身の持つ教材を配信しようとする動機及びその際の障 害は何か?

・ OER 構想へのアクセス性その有用性をどのように改善するか?

本レポートは、国際、国内及びその中間の各レベルにおける実務者や意思決定者に加え、 高等教育機関の管理者も対象読者としている。本レポートは高等教育のみを対象としたもの であるが、提起された問題の大部分は初等・中等教育や社会人教育にも当てはまると考えら れる。初等・中等教育における OER の利用・生産に関する追加的な調査及びその結果は最大 の関心事であろう。

本企画及びプロジェクトの推進は本レポートの主要な著者の一人である Jan Hylén 氏によ って主導された。フランシス・ペドロとトム・シュラー両氏も同プロジェクトの実施と運営 に深く携わってきた。 


\section{謝 辞}

主任研究員グループの皆様には、本研究を進めるにあたり有益な助言を頂くと共に、本レ ポートの執筆に際し有用なコメントを頂いた。同グループの構成員は、Pontydysgu（イギリ ス）の Graham Attwell、UNESCO 国際教育企画研究所(International Institute for Educational Planning: IIEP)の Susan D’Antoni、Danish Technological Institute（デンマーク）の Knud Erik Hilding Haman、ENSTA（フランス）の Francis Muguet、University of Winona（アメリカ）の Sally Johnstone、Macquaire University（オーストラリア）の James Dalziel の各氏である。また、 Blackwell Publishing の Robert Campbell 氏、MIT OCW の Steve Carson 氏、Creative Commons の Mia Garlick 氏、Ministry of Education and Research in Norway（ノルウェー）の Øystein Johannesen 氏、Open University in the Netherlands（オランダ）の Fred Mulder 氏にも、本レポ ートの執筆に際しコメントを頂いた。研究期間中には、UNESCO 国際教育企画研究所から多 大な協力を頂いた。また、European Commission が出資したプロジェクトである European Schoolnet や OLCOS（Open eLearning Content Observatory Services）からも、有益な協力を頂い た。また、専門家会議を主催し、専門論文に出資して頂いた Swedish Knowledge Foundation 及びカタロニアの地域政府にも感謝の意を表明する。

The Canadian Council on Learning (カナダ)、Danish Technological Institute (デンマーク)、 メディア教育開発センター（日本）の各機関にも、それぞれの国におけるケーススタディを 実施する際に必要となる費用を賄って頂いたことを感謝する。CERI のスタッフにより実施 された2つのケーススタディでは、エストレマドゥラの地域政府と National Distance Teaching University of Spain（UNED、スペイン）にその費用を賄って頂いた。これらのケーススタデ イを実施してくださった全ての専門家の皆様及び彼らの訪問調査に際し惜しまず協力してく ださった各研究機関（表 1.1 に記載）に感謝する。

本企画は、William and Flora Hewlett Foundation からの助成金を受けており、同財団に深く 感謝する。OER に対する最初にして最大の出資者の一つである William and Flora Hewlett Foundation は、全世界に対し平等に教育機会を与え、平等に知識へアクセスできるようにす ることを目的とした情報技術の利用を目指している。 


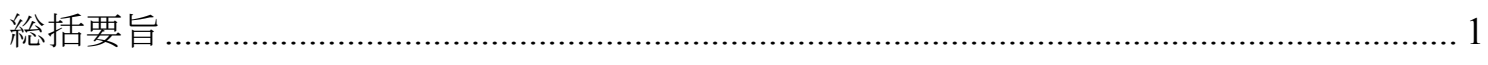

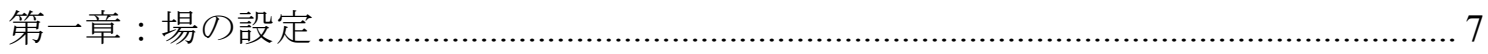

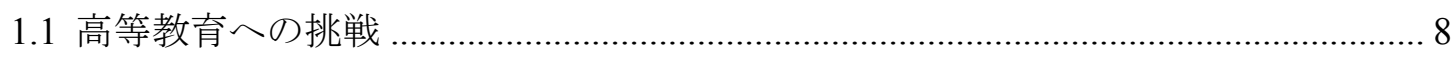

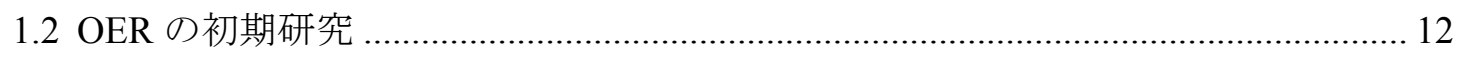

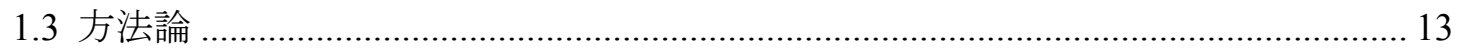

第二章 : オープンエデュケーショナルリソース（OER）とは何かー＼cjkstart概念的諸問題.16

2.1 オープンエデュケーショナルリソース (Open educational ResourcesOER)の定義 17

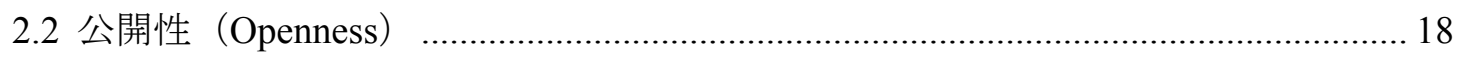

2.3 教育用（Educational） ……...................................................................................... 22

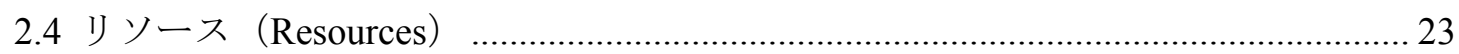

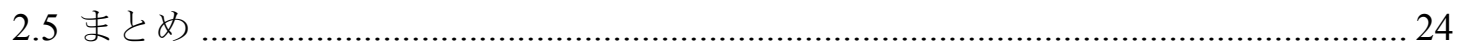

第三章 誰が関与するのか - OER 動向の位置付け …………………………....................... 26

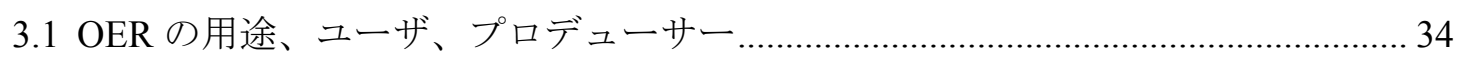

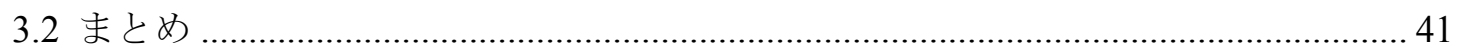

第四章 : 何故共有するのかー オープンシェアリングの動機、利点、障害 ................... 42

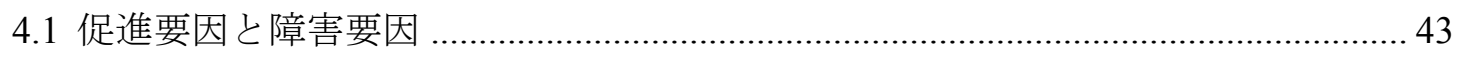

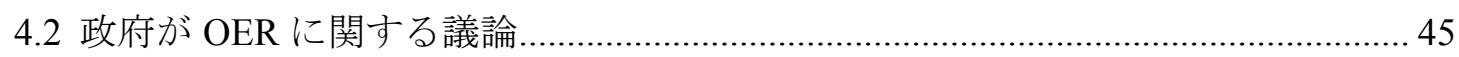

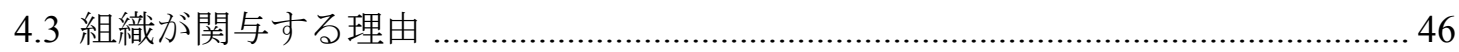

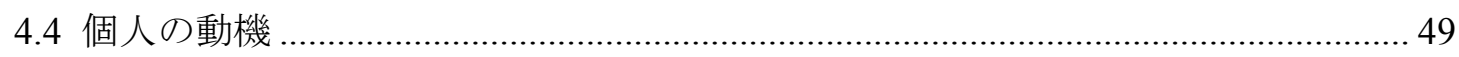

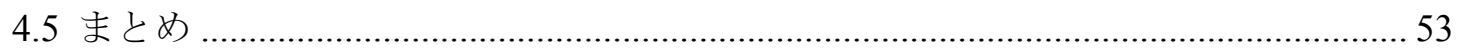

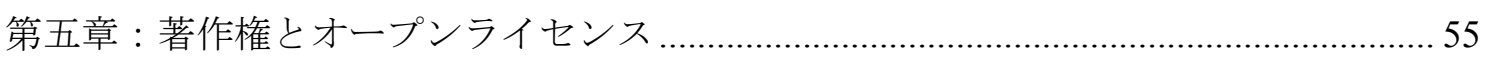

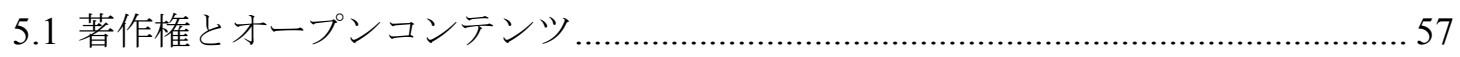

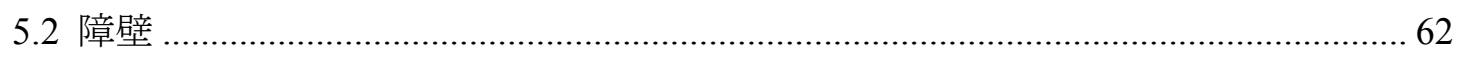

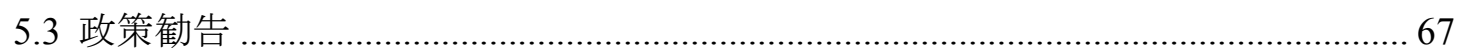

第六章 : OER 企画における持続可能性（Sustainability）の問題 ........................................69

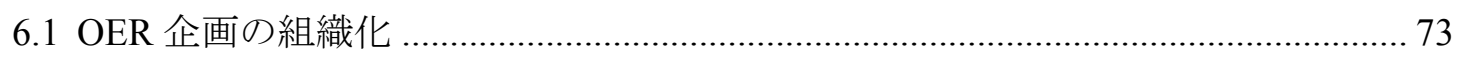

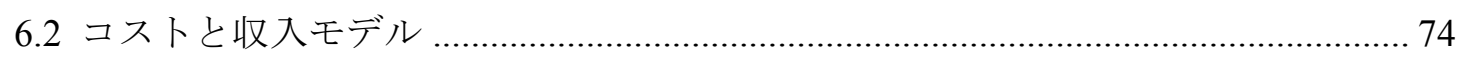

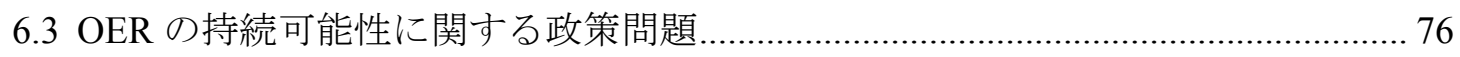

6.4 継続中の OER プロジェクトに関する諸課題のまとめ.............................................. 76 


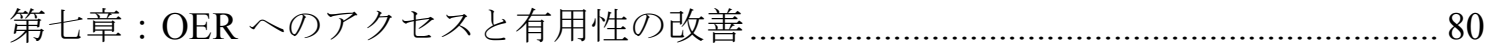

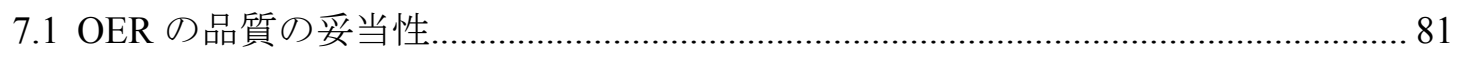

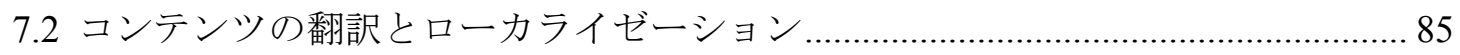

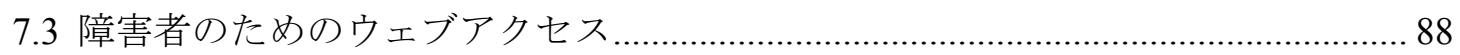

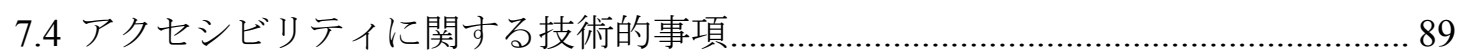

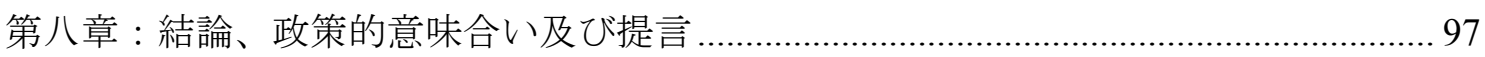

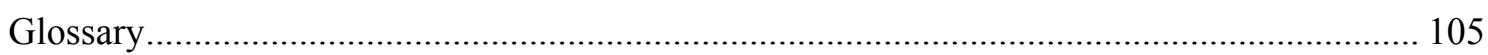

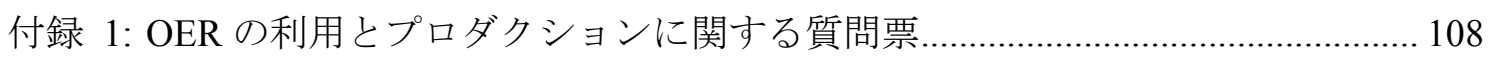

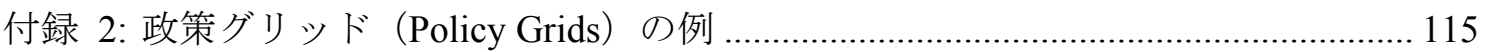

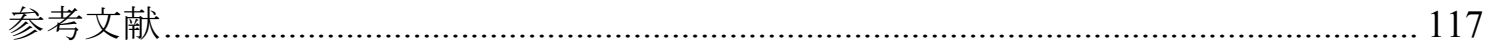




\section{総括要旨}

高等教育界に明らかにただならぬ動きが生じている。競争の激しい高等教育の世界におい て、学習リソースはしばしば重要な知的財産と見なされている。しかしながら、インターネ ットを通じてますます多くの機関や個人が、デジタル学習リソースをオープンに無料で共有 している。これがオープンエデュケーショナルリソース(Open Educational Resources: OER)で ある。この調查報告書は、e-Learning に対する過去の OECD の研究に基づき、なぜこのよう なことが起きているのか、誰が関与しているか、そしてこの発展が意味する最も重要な示唆 は何であるのかを問いかけるものである。

高等教育はグローバル化、高齢化社会、高等教育機関の国内的・国際的な競争激化、急速 な技術の発展など、数多くの課題に直面している。OER はそれ自身が課題の一つであるが、 一方で、個々の機関がそれらの課題に対処するための適切な方策となるかもしれない。オー プンソースソフトウェア(Open Source Software:OSS)に向かう流れやオープンアクセス出版 (Open Access publishing)に向かう流れは既に非常に強力であり、それらはムーブメントとして 一般に捉えられている。今や、そこに学習リソースの共有に向けた流れ、つまり OER ムーブ メントが加わろうとしている。

この報告書は「無償の知識供与」という副題を持つ。これは OER ムーブメントに秘められ た意味合いを明らかにする。OER は魅力的な技術革新であるだけでなく、主要な教育手段と なりうる。OER はフォーマル学習とインフォーマル学習の、また教育とより広範な文化的活 動の境界を一層曖昧にする。また、それは所有の本質、知識の合法的な利用及び利他主義と 共有財の概念などに関する基礎的な哲学的問題を喚起し、世界的な所有権とその配布の問題 にまで発展する。また、OER は、まさにそのような知識の効率的利用がますます個人と国家 にとって経済的な成功の鍵になると見なされる今日、知識共有への革新的な手段をもたらす という側面がある。しかしながら、それがどれほど逆説的であるのか、そしてその見込みが どのような形で実現するのかについては、全く予想もつかない。この報告書は、これまでに 喚起された問題を理解するためのきっかけを提供する。

OER プロジェクトは、全ての人の学習参加の機会を拡大寸るが、その対象の大半は従来と は異なる層の学生であるため、結果として高等教育への参加をおし拡げることとなる。OER プロジェクトは個人や政府が生涯教育を促進する効率的な手段となりうるし、またノンフォ ーマル、インフォーマル及びフォーマル学習の間に横たわる溝の橋渡しとなりうる。

\section{何がオープンエデュケーショナルリソース $(\mathrm{OER})$ か？}

現在最も使われている OER の定義は「教師・学生・自習者が教育・学習・研究するために 利用・再利用できる無料かつオープンなデジタル化された素材」である。学習コンテンツ、 コンテンツを作成・利用・配布するためのソフトウェアツール、そしてオープンライセンス (open license)のような履行のためのリソースなどが OER に含まれる。この報告書は、「オー プンエデュケーショナルリソース $(\mathrm{OER}) 」$ とは目的にあわせた改変が可能で、かつ他人の利 便を損なわずに利益をもたらすようなデジタル資産の蓄積であることを示す。 


\section{誰が、どれだけOER を利用・作成するのか？}

問題となっている学習コンテンツにはオープンコースウェア(Open Course Ware:OCW)であ る。例えば、講座として構成され、一般にPDF ファイルのような形で配布される教材は、小 さな学習チャンク (chunks of learning) と同様に、ラーニングオブジェクト(learning object)と呼 ばれる。学習コンテンツはウェブサイト、シミュレーション、文書ファイル、画像、デジタ ル形式の音・映像などかもしれない。それらには利用のみ許されるものもあれば、改変や再 利用が自由なものもある。明確な統計は存在しないが、OER プロジェクトの数は関係者の 数・利用可能な資料の数と共に急速に増加し続けている。2007 年 1 月、OECD は世界中の 300 以上の大学において、3000をこえるオープンコースウェア講座が利用できることを確認して いる。MERLOT、Connexions、OpenLearn やその他のリポジトリ(repository)には数十万のコン テンツや素材があり、それらを使えば数千時間もの間、無料で学習寸ることができる。今の ところ OER プロジェクトの支配的な言語は英語であるが、増加傾向にある非英語 OER プロ ジェクトと協調して資料が翻訳されることで、増加する言語多様性・国際利用への要求は満 たされる。従って、潜在的なユーザ数は莫大といえる。

OER の利用者と作成者については、散在する利用可能なデータにより概要だけがわかって いる。OER プロジェクトの資料の作成者の大多数は英語圈の先進国にいる。ムーブメントは トップダウンと、ボトムアップの両方で起っている。つまり、機関のレベルで新たなプロジ エクトが始まると同時に、個々の教師や研究者が自主的に OER を利用・作成している。これ までのところ、無名の機関や評判の低い機関よりも、国際的・国内的に評判が高い機関がこ のムーブメントに関わっているようである。

\section{なぜ人々は無料で共有するのか?}

個人や機関が OER を利用・作成・共有する理由は、基礎技術的・経済的・社会的・法律的 要因にわけられる。

・ 技術的・経済的要因には、高度・低コスト・ユーザフレンドリーである、(例 えばブロードバンドのような)情報技術インフラ・ハードウェア・ソフトウ エアが挙げられる。共有によって、コンテンツがより安く・より容易に作 成可能となり、コストはさらに減らすことができる。無料のコンテンツの 配布と関連して、新しい経済モデルが出現している。法律的要因には、コ ンテンツの共有と再利用を促進する新しいライセンス手法がある。社会的 な要因には、増加する共有への意欲が挙げられる。

・技術的な障壁は、ブロードバンド普及の欠如である。経済的な障壁は、OER を作成・共有するためのハードウェア・ソフトウェアへの投資の欠如であ る。これらの障壁はしばしば開発途上国において重要な障害であるとされ る。社会的な障壁には、革新的な技術を使用する技能の欠如と、他の教師 や機関が作成した資料を共有・利用することに対する文化的な抵抗が挙げ られる。 
政府が OER プロジェクトを支援することについては、三つの議論がある。

・ OER プロジェクトは、全ての人の学習参加の機会を拡大するが、その対象 の大半は従来とは異なる層の学生であるため、結果として高等教育への参 加を押し拡げることとなる。

・ OER プロジェクトは個人や政府が生涯教育を促進する効率的な手段となり うる。

・ OER プロジェクトはまたノンフォーマル、インフォーマル及びフォーマル な学習の間に横たわる溝の橋渡しとなりうる。

OER プロジェクトに機関が関わる理由として、関係機関は 6 種類の理由をあげている。

・ 知識の共有という利他的な目標は、アカデミックな伝統に沿っており、よい ことである。

・ 教育機関(特に公的な財源を持つ機関)は、リソースの自由な共有と再利用を 許可することで納税者の金銭を効率的に活用すべきである。

・ 共有と再利用によってコンテンツの品質を向上させ、コストを削減すること ができる。

・ 新しい生徒を引き付けるショーウインドウとして OER プロジェクトを行う ことは、教育機関の広報活動に良い影響がある。

・ 多くの教育機関が競争激化に悩む中、新しい原価回収モデルを模索する必要 がある。

・ オープン共有は新しい学習リソースの作成スピードを上げ、内部的な改善・ 革新・再利用を促し、素材とその素材の内部的・外部的な使用に関寸る有 用な記録を教育機関が保持しやすいようにする。

大手の遠隔教育機関には、変化の激しい環境において無策であるが故のリスクを更なるモ チベーションとしてあげるところもある。

個々の教員・研究者のモチベーションは以下の 4 つの項目に要約される。

・ 教育機関と同様、伝統的なアカデミックな価值観に支えられた利他的なモチ ベーション。

・ 知名度、「エゴブー(egoboo)」、オープン・コミュニティ内での評判のよう に、個人的で非金銭的な利得。 
・ 知名度を得るため、市場により迅速に到達するため、先行利益を得るための 手段として、自由な共有は経済的・営利的な理由で有用である。

・資料をクローズにしておいても得にならないこともある。従ってもしそれが 他の人にとって何らかの価值があれば、むしろ無料で共有した方がよい。

機関が OER プロジェクトに関っているかどうかに関わらず、OER はカリキュラム・教授 法・評価法に対して衝撃を与えるだろうと考えられる。国際的に評判の高い高等教育機関に よる、無料で利用可能な何千もの（オープンコースウェア上の）講座によって、教師は自ら のカリキュラムが学生によって他者と比較されると考える必要があるだろう。文献リス卜と 教材の供給者としての教師の役割は小さくなっているため、OER は伝統的な教師の役割の変 化と、より自立した学習者の進化を加速しそうだ。ノンフォーマル学習とインフォーマル学 習の増加により、フォーマルな学習環境以外で得られる能力を評価・認識する需要が増すと 考えられる。

\section{著作権とオープンライセンス}

著作権法の定義は国際条約に由来しており、ほとんどの国で類似している。著作権は、著 作者にその著作物に対する独占的な権利を時限的に保証することによって、主に経済的な効 果をもたらす。情報技術を使用すると、コンテンツをほとんど無料で世界中に配布・拡大す ることができる。一方で、著作権保護がなされた素材を再利用しようとすると、法的な制約 がデジタル環境における流通性 (negotiability)を阻害する。この障害に不満を持つ世界中の研 究者達は、著作権保護がなされた素材を訴訟の恐れなしに共有・再利用することができる空 間をインターネット上に創り出すため、オープンライセンスを利用し始めた。すなわち、ク リエイティブ・コモンズ(creative commons)である。そのために、著作権の保有者は、彼らの 素材が事前承諾型のライセンスを通じて共有されることに対して、同意や許可を与えなけれ ばいけない。クリエイティブ・コモンズのライセンスを利用するコンテンツは現在爆発的に 増加中であるため、このライセンスは群を抜いて有名なものになっている。

\section{どうすればOER プロジェクトを長期的に維持できるのか}

OER プロジェクトにかかる実際のコストは非常に多様である。プロのスタッフを含めた組 織的な支援を得ている試みもあるし、専門家のコミュニティに立脚しボランティア活動に頼 っている試みもある。さらにこれらの中間的なモデルも無数に存在する。リソースを共有・ 交換するための場所として、リポジトリ(repository)を構成することができる。それにより、 人々は利用者であると同時に作成者であるようになる。あるいは、共有リソースの協調的な 生産が促されることになる。

最初のモデルは producer-user モデル、二つ目のモデルは co-production モデルと呼ばれる。 これら二つは連続している。最初のモデルは後者よりも中央集権的であるようである。OER プロジェクトにかかる本当のコストは金銭ではなく資料かもしれないが、それでも大抵の試 みではいくらかの資金を調達しなければならない。そのために、この報告書では次のように 多くの原価回収モデルを確認している。まず、交換(replacement)モデルはオープンコンテン ツが他者の使用や利益を置き換えることで省コストとなる。基金・寄付・贈与(foundation, 
donation, endowent)モデルは外部の関係者がプロジェクトに資金をもたらす。区分化 (segmantation)モデルは供給者が「付加価值のある(value-added)」サービスを特定の区分の使 用者に提供してその区分の利用者に課金する。転換(conversion)モデルは「何かを無料で提供 することで、消費者を購買客に転換する」。また、ボランティア(voluntary)モデルや会員 (membrership)モデルは募金キャンペーンや有料のメンバーによって成り立つ。

\section{OER のアクセス性び及び便利さの向上}

オープン・ムーブメントの提唱者達は、既存の資料のアクセス性と便利さを向上する方策 を考えなければならない。学習教材とリポジトリ (repository)の数は急速に増大しているので、 最も関連性が高く品質の高いリソースを探し出すことが重要になる。メタデータ (Metadata; 資料についての説明情報)は検索エンジン(search engines)の能力を向上させるかもしれないが、 良質なメタデータをリソースに付加するのは容易でなく、非常に時間がかかる。他にも自動 的にメタデータとフォークソノミー(folksonomy)を生成する手法が現在試されているが、スケ ーラブル(scalable)な解決法はまだ見つかっていない。品質(Quality)は様々な方法で向上寸る ことができるだろう。

OER のプロビジョン(provision)とユーティリゼーション(utilisation)の間には厄介な不均衡 が存在する。OER の圧倒的多数は英語と西洋文化に基づいており、そのことが妥当性を制限 し、より少数の先進国に消費者の役目を委ねている。発展途上国では、自国の言語と文化に 基づいて OER を作成する多数のプロジェクトが既に存在する。

OER の概念は、素材を再利用し再び目的を持たせる(repurposing)というアイデアに立脚し ているため、相互運用性は重要な問題である。学習リソースはリポジトリを横断して検索・ ダウンロードが可能であり、かつプラットフォームを越えて統合・適応できる必要がある。 ソフトウェアアプリケーションは、異なる場所・時間で異なる開発者によって開発されたも のでも、協調して運用可能であるべきである。オープン標準(Open standard)がそれを可能とす る。新たな標準規格の開発は専門的な課題であり、財政的な支援が必要である。

\section{政策の示唆及び推奖}

OER ムーブメントは多くの政策レベルで示唆を持っている。著作権に関する立法の協調や 標準規格に関する議論のように、相互運用性に関する問題は国際的なレベルで扱われなくて はいけない。OER ムーブメントに関する良い知識基盤(knowledge base)を国際的に開発するこ とが必要である。また、その開発には、OER の概念をより広く知らしめる啓蒙活動が伴うべ きである。あらゆるレベルの資金援助団体はこれらの活動を支えるよう推奨される。

国内的なレベルの OER プロジェクトは、フォーマル学習とインフォーマル学習の境界が一 層曖昧になっていることを明らかにしており、国々は増加する生涯学習への要求を満たすた め、OERの効率的な利用方法の研究を奨励している。OER は多様化した学習リソースの供給 に対し重要な貢献をすることができる。十分に供給されたデジタル学習リソースは、学習過 程の個性化を促すために不可欠な、方法論的多様性を支える。政府は OER も含めたデジタル 学習リソース全体に対して、総合的なアプローチをとるようアドバイスされる。 
教育における情報技術の更なる活用を促すための既存の著作権体制の見直しでは、商業関 係者とOERに関して、少なくとも中立的な政策を作りだすように考慮すべきである。国家的 なデジタルアーカイブや博物館のコレクションは、教育分野に広く公開されている。OER を 促進する意思のある政府はそれと同様に、公的な資金を得ている機関で作成された教材を広 く公開するため、教育に対し一定の資金を割り当てるべきである。

官民のパートナーシップは、お互い分野のノウハウとリソースを結び付ける方法としてよ り利用されるべきである。可能かつ適切であればいつでも、オープン標準を使用すべきであ り、オープンソースソフトウェアライセンスが適用されるべきである。

OER ムーブメントの急速な発展は、すぐに高等教育機関に衝撃を与えることになるだろう。 これによって、教育機関の運営では無策であるリスクが考慮されるようになる。高等教育機 関は、OER ムーブメントがもたらすチャンスと危険への対応手段を含めた、情報技術戦略を 持つようにアドバイスされる。OERがもたらすチャンスを捉えようとする機関は、教職員が この試みに参加する誘因を作り出すべきである。例えば、テニュア・プロセス(tenure process) の一環として、 teaching portfolio に少なくとも一つは OER に関する項目を加える、などが挙 げられる。教育における OER の利用は奨励されるべきであり、そのための訓練が提供される べきである。 


\section{第一章}

\section{場の設定}

本章では、グローバリゼーション、人口統計の変化、変容するガバナンス及びテクノロジー という 4 つの高等教育のチャレンジについて述べ、どのように OER がこれらのチャレンジに 関連しているのか論述し、使われる手法を紹介し、OERに関する初期の研究の見直しを行う。 
オープンエデュケーショナルリソース（OER）として、学習リソースがしばしば競争の激 しい高等教育における知的財産の要と見なされているにもかかわらず、ますます多くの機関 と個人はインターネット上に彼らのデジタル学習リソースを無償で公開し OER として共有 している。以下の研究は、これがなぜ起こっているのか、誰が関与しているのか、そして、 その最も重要な意味合いは何であるのかを問いかけている。

\section{1 高等教育への挑戦}

OECD 域内で高等教育機関が直面しているいくつかの挑戦を挙げることで、OER ムーブメ ントが展開している理由を示すことができる。高等教育の将来に向けての OECD プロジェク 卜は、政府の政策決定者と高等教育における利害関係者に知らしめ、また戦略的な変化を促 進するために最近の変化と傾向を分析している（www.oecd.org/edu/universityfutures）。この プロジェクトによると、グローバリゼーション、人口統計学、ガバナンスへの新しいアプロ 一チ、テクノロジーという 4 つの趨勢が、来たる数十年に高等教育に及ぼすインパクトとし て際立っている。

\section{グローバリゼーション}

世界経済のグローバル化は、カリキュラムの国際化への重要性と共に教育の国家の境界を 超えた浸透をもたらしている。高等教育の国際化は、国家間、機関のプロバイダの間に連携 と競合をもたらすという両刃の現象であると思われる。OECD の教育政策分析（2006a）は、 国境を超える高等教育が過去の数十年にわたって目覚しく成長したと報告しており、また今 後もこの成長は続くと予想している。1998～2004 年には、OECD 域内の留学生数は 70\%増の 230 万人に達した。この発展は、いくつかの相互に関連する要因によって促進された。ます ます知識ベースとなっている経済における熟練労働者のより大きな移動性、輸出産業を拡張 し、高等教育における国際連携を拡大寸る動き、教育のオプションが限られている送り手の 国に教養のある労働人口を育てる必要性、国際的な経験により相互理解を促進したいという 学生と研究者の願望、そして、輸送と通信コストの下落といった相互に関連する誘因によっ てもたらされたのである。

教育政策分析によると、この発展は、学生と研究者に国家と高等教育機関間のさらなる競 合をあおった。同時に、品質表示、様々な努力と消費者選択によって明らかにされた任意の 調和化課題（例えば、ラテンアメリカとアジアにおいてより小さなスケールで類似した構想 をもたらしたヨーロッパの Bologna Process）の下で、また国際的な比較の圧力の下で、また は協力と認知協定の頻度の増加の故に、国内の高等教育システムは、ますます国際的圧力と 競合に直面するのである。以前の確立した研究大学の様に、全てのタイプの高等教育機関は、 国内の役割や課題に捉われることなく、ますます自分たちを世界市場における行為者とみな している。

世界中の教育機関間のさらなる連携と、言語のまま、あるいは翻訳されるか、適合化され た学習リソースの再利用を通して、OER 現象は、高等教育のグローバリゼーションに貢献す る。同時に、世界に広がる潜在的ユーザの目に見える個々の教育機関内に教育内容とプロセ スをつくりあげることで、機関間の競合をさらに増幅させる。将来の学生は機関から一般的 
に提供されたものを学習するだけでなく、個々の学科のカリキュラム及び学習教材を見て、 また時には録画された講義を見ることによって、より学習内容に精通するようになるであろ う。

\section{人口統計学}

OECD 社会が高齢化するにつれ、場合によっては縮小寸るにつれ、国家は高等教育におけ る人口統計学的要因のインパクトにますます関心を持つようになってきている。伝統的な 18 一25才の学生年齢層の減少は、いくつかの OECD 諸国で機関に影響を及ぼしている。この減 少は、参加率、留学生の増加（若者の数は、教育のための需要が完全には満たされない多く の非 OECD 諸国で増加している）、そして、教育を受けたい年配層の増加傾向と彼等へのプ ログラムの供給により相殺されるかもしれない。一部の例外を除いて、高等教育制度は、よ り短期的なコース、より柔軟な配布、以前の学習の認知、そしてオーダーメイドのプログラ ムという生涯学習者の要求に適応するのが遅かった。多くの転職を伴う長い労働人生と高等 教育への退職者の入学増加の可能性は、しばらくの間本当に変化を引き起こす力となるかも しれない。

ほとんどの国々は、高等教育への参加を増やす必要がある。これまで、高等教育機関は一 般にこの要求に応じることができなかった。OER 構想は、高等教育機関への参加を広げるこ とで高等教育機関を従来とは異なる学生グループへの援助活動の手段として扱うかもしれな い。そして従来の教育手段を利用することができない学生と伝統的な高等教育入学者でない 人々に学習機会を与えるかもしれない。OER 構想はノンフォーマル学習、インフォーマル学 習、フォーマル学習間のギャップを埋めることができる。同時に、OER は高齢化社会の挑戦 に取り組む方法として生涯学習に新しい戦略を開き、プロによる現職トレーニングと高齢者 による在宅学習のために利用することができる。

\section{自治（ガバナンス）を変える}

教育政策分析は、多くの OECD 諸国で新しい方法で国の権威と市場のパワーを組み込んだ 新たな自治へのアプローチを報告している。より望ましい公共経営を求める強い要求がある。 高等教育機関が現在実行中であり、今後ますますその実行を求められる、アカウンタビリテ イ、透明度、効率と有効性、応答性と将来への展望は現在、望ましい公共的ガバナンスの主 要な構成要素と看做されている。そして、高等教育機関はそれを実行するよう依頼され、今 後もますます依頼されていく。この点で、機関ベースの OER 構想は、登録された学習者とイ ンフォーマル学習者からの直接のフィードバックだけでなく、機関、部局または個々の教職 員の間で強化された透明度と比較性によって改善された品質管理の要求を満たすと言われて いる。

さらに、より多くの自治と企業家精神へのシフトが広がり、そして非常に異なるプロフィ ールをもつ機関はますます、国内で、そして国境を超えて互いに競合することができると言 われている。これらの事項は、国家予算優先度、資源使用の効率、高等教育の組織と高等教 育の個人的な供給、どのように経費を社会の異なるグループ（納税者、学生と家族（会社）） で分配するべきかについての議論の中で決定される。機関は、ますます、彼ら自身の戦略を 
開発して、彼ら自身の優先度を決定することが自由にできるようになる。政府と他の政策立 案者は、効率性と優秀性の奨励を公平性の推進と結合させなければならない。この意味にお いて、納税者のお金のより良い費用対効果を確実にした一般の資金提供によって開発した学 習リソースとツールのより広い循環、共有及び再利用は、政策立案者と機関と資金提供組織 の代表にとっての関心事となるはずである。

\section{高等教育における芰術とe-Learning}

情報と通信技術の絶え間ない開発は、知識経済の先導者の 1 人である。学生向けポータル、 インターネット接続、デジタルライブラリとラップトップコンピュータ、携帯装置と他の携 帯機器の入手可能性を通して、テクノロジーは高等教育で普及し続け、キャンパスでの学生 の体験を既に強化してきた。e-Learning は、教育番組の主流の一部になっている。コンピュ ータとネットワークパフォーマンスの急速な加速のおかげで、デジタル技術はアカデミック な研究も劇的に変えた。そして、それは研究者が大量のデータセットへアクセスし、操作し、 より多くの複雑なシステムをシミュレートし、モデル化し、可視化し、研究において国際的 なコミュニケーションと協同を強化するのを可能とした。教育方針分析はこれらのテクノロ ジーが何人かによって予測されたほど完全に教育と高等教育への接近に革命を起こさなかっ たと主張する。そして、彼らの過去の影響と将来の約束は現在、より用心深く考慮される傾 向がある。他の革新のように、e-Learning は、将来その可能性に従って生き残っていき、教 育、学習、相互作用の新しい方法を可能にするかもしれない。学生の期待は、重要な要因で す。10 年の高等教育に入る人々の多くは、彼らが学習とゲームのためにインターネットにア クセスしなかった時を決して知らないだろう。New Millennium Learners と呼ばれている、来 るべきプロジェクトで、OECD は新技術の日々の使用がどのように人々が学ぶ方法に影響を 及ぼすか、そして、学習のこれらのパターンがどのように正式な教育制度で続くかというこ とと関係があるかを調査する。

OECD（2006b）で記述されたもう一つの傾向は、高速なブロードバンドアクセスと新しい ソフトウェアツールを普及させることによって導かれる、デジタルコンテンツの開発におけ る、創造的な参加急成長が、社会と経済の新しい特徵であるということである。インターネ ットの使用は、通信し、自己を表現するためにそれを使うインターネット利用者の更なる参 加と相互作用によって特徵付けられる。より広範囲にインターネットの固有の能力を使うこ の進化を記述する最も突出した概念は、参加型ウェブ（またはウェブ 2.0）と呼ばれている。 それはインターネットをますます開発し、評価し、共同し、インターネットのコンテンツを 配信し、インターネットアプリケーションを開発しカスタマイズすることが増加している一 因であるユーザに公的な権限を与えている新技術に基づく知的なウェブサービスによって影 響される。ユーザによって作られた内容の高まり又はアマチュアクリエーターの高まりは、 参加型ウェブの中心柱である。これは、メディアのいろいろな形とインターネットによって 作成される創造的な作品（文書、音声、視覚的なもの、そしてそれらが合わさったもの）と テクノロジーの使用権（写真のような無線装置から、コンテンツを含む）から成る。OERの 現象は、教育セクターの中のデジタルコンテンツ開発への創造的な参加の出現と見なすこと ができる。 
解説の通り、高等教育の e-Learning はここまで、ドットコムブームの間、期待に応えては こなかった。しかし、たとえ OECD 地域の高等教育で e-Learning の使用に首尾一貫した統計 がないとしても、それはオンライン教育が成長していて、ますます著名になっていることは 明らかなようである。OECD（2005）は大学が e-Learning の供給を徐々に増やしていて、多 くの学生が e-Learningに登録していることを示した。「e-Learning」の概念は電子メールを使 い、キャンパスでのコースに従ってオンラインで提供されるコースにアクセスしている学生 から、オンラインだけで提供されるプログラムまで広範囲にわたるシステムをカバーした。 ウェブで補われたコース、ウェブに依存するコース、混在コース及び完全にオンラインの 4 つのカテゴリが使われた。結論は e-Learning を受講する学生が増加しているということだっ た、しかし、キャンパスに重点を置く大部分の機関では、ウェブ依存のコースと、完全にオ ンラインのコースの全ては良くても 5\%以下の登録しかなかった。さらに、大部分のキャン パス重視の機関では、e-Learning の成長が教室での対面教育が中心的なままであるという事 実を変えなかったと結論した。

コースの少なくとも $80 \%$ がオンライン配信されているコースについて言及した、継続した 4 年間の USA でオンライン学生とその提供数の安定した増加を報告するスローン協会 (2006) からのレポートで、高等教育における e-Learning の明るい現況が伝えられている。 US degree-granting 機関で少なくとも 1 つのオンラインコースを受講している学生の数は 2002 年の 160 万から 2005 年には 320 万人まで増大した。そして、それはUSA で全ての高等教育 学生のほぼ $17 \%$ 意味する。調查に応じた 2,200 以上の単科大学と総合大学の $58 \%$ 以上は、 オンライン教育が機関の長期戦略に極めて重大であると言う。しかし、e-Learning は数の面 だけ成長しているわけではなく、品質も向上しているようである。大多数（62\%）の教育機 関の指導者は、オンライン学習が対面学習と同程度か、それより優れていると考えている。 その割合は、2003 年の $12 \%$ からぼ 17\%まで増大した。8\%未満は、学習結果の観点からオ ンライン学習が劣っていると考えている。

たとえスローンの調査で多少なりとも完全なオンラインコースの重要な成長を報告すると しても、それは最も一般的であるブランデッドラーニングによる方法であるようだ。大学教 員と管理者（大部分は米国と 2 つ他の類似した組織からの MERLOT のメンバー）の 2003 年からのオンライン調査に基づく研究は、ブランデッドラーニングとオンライン component を用いる学習が少なくとも対面授業と同じくらい高いか、より高い成長の予想を示す (Kim and Bonk (2006）)。OECD e-Learning report と共に、この研究は、再使用できる component には近い将来、重要な影響があると予測する。彼らは内容からの展望から学習を見る危険に 触れるが、著者は「これらの調查結果は、既存のコンテンツを共有し、使用するオンライン 技術の認められた重要性を反映するようである」と結論する。

要約すると、技術開発は、新しい大通りを開放している、そして同時にそれが高等教育へ の財政的、技術的、質的な挑戦であると述べている。完全にオンラインで提供されるコース、 ブランデットラーニングに関する見地と、対面での教育と比較してオンライン学習で多分さ らによりよいであろう学生の学習結果の品質に関する見地から、e-Learning の役割は成長し ている。2006 年 11 月の the International Council for Open and Distance Education (ICDE)が Global Open Educational Resources Task Force を打ち出した。そこでは以下のように述べられている。 
「将来効果的で良質な e-Learning の主な推進力の 1 つは OER でありそうだ。そして、それは 誰でも世界の知識を共有し、使用し、再利用寸る途方もなく大きい機会である」(ICDE、2006)。

\subsection{OER の初期研究}

OERについての初期の研究を見てみると、その発端を最近生まれた「オープンエデュケー ショナルリソース」という用語にとっており、オープンコースウェア、ラーニングオブジェ クト、オープンソフトウェア及びオープンライセンスなどその全ての異なった構成要素を含 んでいる。後半のアプローチは、この報告書の範疇を超えている。初期 OER 動向に関する研 究の最小限度のアプローチは、 $2 ， 3$ の用語を述べているだけである。Johnstone と Poulin (2002)は、MIT の企画を例示して初期の OER とは何であるかについて概観している。その中 で彼らは、いかに著作権問題など OER を世界中に広めるにあたってのいくつかの技術的に重 要な問題を解決したか述べている。Moore(2002)は、オープンソース開発ツールとオープンコ 一スウェア（コンテンツ）を区別した初期の研究者の一人である。彼女は、高等教育機関へ の関わりについて、全ての機関がオープンソースプロジェクトの支援をする必要はなく、た まに素材提供したり論評者として参加寸る方がいいのかも知れない、としている。さらに、 Werry(2003)を引用して、オープンソースムーブメントの主な障害は、組織、調整、政治動向 及び資金であって、専門性や全体的な財源やスキルの欠如ではないことに注目している。 Keats(2003)は、オープンソフトウェア開発から学んだ教訓を踏まえ、コンテンツの共同開発 のためのプロセスモデルについて述べており、同モデルがアフリカの諸大学のポテンシャル を開発する鍵になり得るのではと考えている。Siemens(2003) は、教育者が無償でラーニン グオブジェクトをシェアする多くの理由を挙げている。その理由には、デジタルリソースの 共有にはコストがかからない、教育者に選択の余地を与え市場での競合を増進させる、民主 的であり公教育を維持する方法である、ことなどがある。

これらは、プログラマがソフトウェアプログラムを交換するのと同様に、教育者の間で学 習リソースをやりとりする初期の段階を論述した初期の論文であるが、Materu(2004)のもの が、おそらくは後に OER と呼ばれるようになった事象の最初の包括的な報告書であろう。そ の中で、彼が呼称するオープンソースコースウェアは米国の主導で世界のあらゆる国々に関 心を喚起したと結んでいる。その概念は、高等教育機関における学習にどのような効果があ るかはこれから測らなければならないが、オープンコースウェアは発展途上諸国の機関には 考慮す心゙き好機会であると見なされている。しかしながら、Materuは、これら諸国の参加は、 特定の環境に即したコースウェアを採り入れ開発するのに必要なリソースがないために制約 されると報告している。

2004 年になると OER のリポジトリ(repository)に関する記事や論文が書かれるようになっ た。Hart と Albrecht(2004)は、オンラインリポジトリと“レファラトリ”（リソースへのリン クをホストするウェブサイト、リソースそのものではない）の実情を調べ、教員、学生、IT 支援及び機関の方針と発展へのインパクトについて模索している。また、リポジトリとレフ アラトリのサイトの事例を示し、それが提供する内容を説明し、教員と学生へのリソースの 潜在的インパクトについて論述し、そしてこれらのリソースの機関や情報技術スタッフへの 利点、チャレンジ及び機会について考察している。2005 年には、UNESCO 国際教育企画研究 
所(IIEP)が、OER に関するディスカッションフォーラムを立ち上げ、既存のプロジェクト事 例と共に、その時点での OER 動向の概観を Johnstone がとりまとめたバックグランドメモを 発行した。今後の OER 企画推進には、多くの創造的な人々が率先して貢献しリソースを利用 していくことが必要となろう。それは、知的資産活用のために壮大だが達成できる事業を進 めていくということである。二番目のバックグランドメモには、学んだ教訓と今後の課題と 共に、MIT の Open Course Ware(OCW)、Rice University の Connexions、Carnegie Mellon University $の$ Open Learning Initiative 及び Utah State University $の$ Center for Open and Sustainable Learning という 4 つの主要な OER プロジェクトが記述されている。

その他の情報源としては、個々のプロジェクトの評価レポートがある。2004 年 3 月から MIT は、毎年 MIT OCW ウェブサイトの評価レポートを刊行している(Carson, 2005, 2006a)。 これまでのレポートはユニークで OER ムーブメントにとっての知識基盤を構築するための ものであり、他のプロジェクトでも同様のレポートを出版することが望まれる。また、興味 深いものとしては、2005 年と 2006 年に Utah State University で開催された OER に関する会議 の議事録があり、これは読者に多くの OER プロジェクトとそれらが取り組んでいる課題を提 供している(USU, 2005, 2006)。最後に、2006 年 3 月には、UNESCO 国際教育企画研究所(IIEP) が、有用な OER のリソースについて、中でも OERの背景についての記述も付した Wiki をス タートし、これは一般の支援を得て継続的に更新されている。

\section{3 方法論}

本研究は、分析的な要素と経験的な要素によって実施された。最初の要素では、継続性の 問題とコスト / 利点モデルが、知的所有権に関する問題や OER を利用し作成することに対す るインセンティブ、障害及びアクセシビリティの問題と共に検討された。専門家から委任さ れるいくつかの論文は、現在プロジェクトのウェブサイト（www.oecd.org/edu/oer）で閲覧可 能である。これらの問題は、2つの専門家会議の主な焦点でもあった。会議は小規模で、招 待ベースで、専門家（及びプロジェクトウェブサイト）によって用意されたバックグラウン ドノートを基にしたワークショップとして実施された。

研究の最初の調查結果を共有し、国際社会でその報告を熟慮する機会を提供するために、 UNESCO 国際教育企画研究所(IIEP) と OECD 事務局によって 3 週にわたるインターネットデ イスカッションフォーラムが組織された。フォーラムを通して、参加者には調査のいくつか の結果と結論を内覧し、それらにコメントし、最終版に貢献する機会があった。その分野の 以前の研究を見付ける机上研究は、プロジェクトの分析的要素の第 3 の部分を形成する。

プロジェクトの経験的な要素は、ウェブによるアンケートと高等教育機関からの事例研究 という $2 つ の$ 部品から成る(表 1.1 参照)。事例研究は、CERI スタッフと外部の専門家によっ て行われた。事例研究は、事務局によって開発されたガイドラインに基づいて実施された。 調查結果の報告一部は、プロジェクトウェブサイトに掲載してある。サイト訪問の目的は、 OER を使用し、開発し、共有する方法と理由に関する深い洞察を得ることによって、アンケ ート（機関と個々の教職員に送付された）を補足するためだった。視察する機関の選抜は、 時にはあまり意味はなかったが、OER の実際の利用と開発に基づく基準と、調查を行う専門 
家自身の知識と彼らの国の特定状況にどの程度精通しているかを基にして行われた。さらに、 OER（知的所有権に関する政策を含む）の利用、開発、そして、共有に関する組織の方針と 実施状況はサイト訪問の重要な関心事だった。2006 年の間に全部で、11 カ国の 21 の機関に 対し訪問調查が実施された。

二つのアンケートが、プロジェクトの一部として実施された。一つは個々の教員と研究者 を対象としたもの、もう一つは OER 活動に関係する機関に向けたものである。個々の教員と 研究者の調査はウェブによるアンケート（付録 $\mathrm{A}$ 参照）として実施された。アンケートへの 依頼は、OER ムーブメントにおいて異なる方法に関係するいくつかの会報、ブログとウェブ サイトに掲載された。依頼状は英語と（場合によっては）フランス語で配布された。しかし、 アンケートそのものは英語によるものだけであった。アンケートは、2006 年に 6 カ月の間参 加のために公開された。全部で 247 の項目が作られたが、いくつかは空白だった。一般的に 各々の質問に対する答えは 180-190 程度得られた。アンケートの全ての結果を分析した論文 は、プロジェクトウェブサイトに載せられている。

OECD 地域（合計 1846）の半数の大学に対し、機関を対象とするアンケート票が電子メー ルで送付されたが、結果を使えないような低い回収率に終わった。期待外れの結果は、おそ らく、英語、フランス語、スペイン語で送られた電子メールアドレスに問題があったことと 言語能力の欠如、また OER における活動がおそらくその大部分は未だ大学の経営陣の関与の ない個々の教師と研究者グループの間での草の根活動に留っていることが原因と思われる。

機関からの回答を個々の教員と研究者からの回答と照合すると、回答が類似している。ど のような結論であれ機関からの回答から導き出すという点では、OER を利用したり作ってい る個人からのものとそれほど違いはないように思われる。 
表 $1.1 \mathrm{OECD}$ ケーススタディへの参加機関

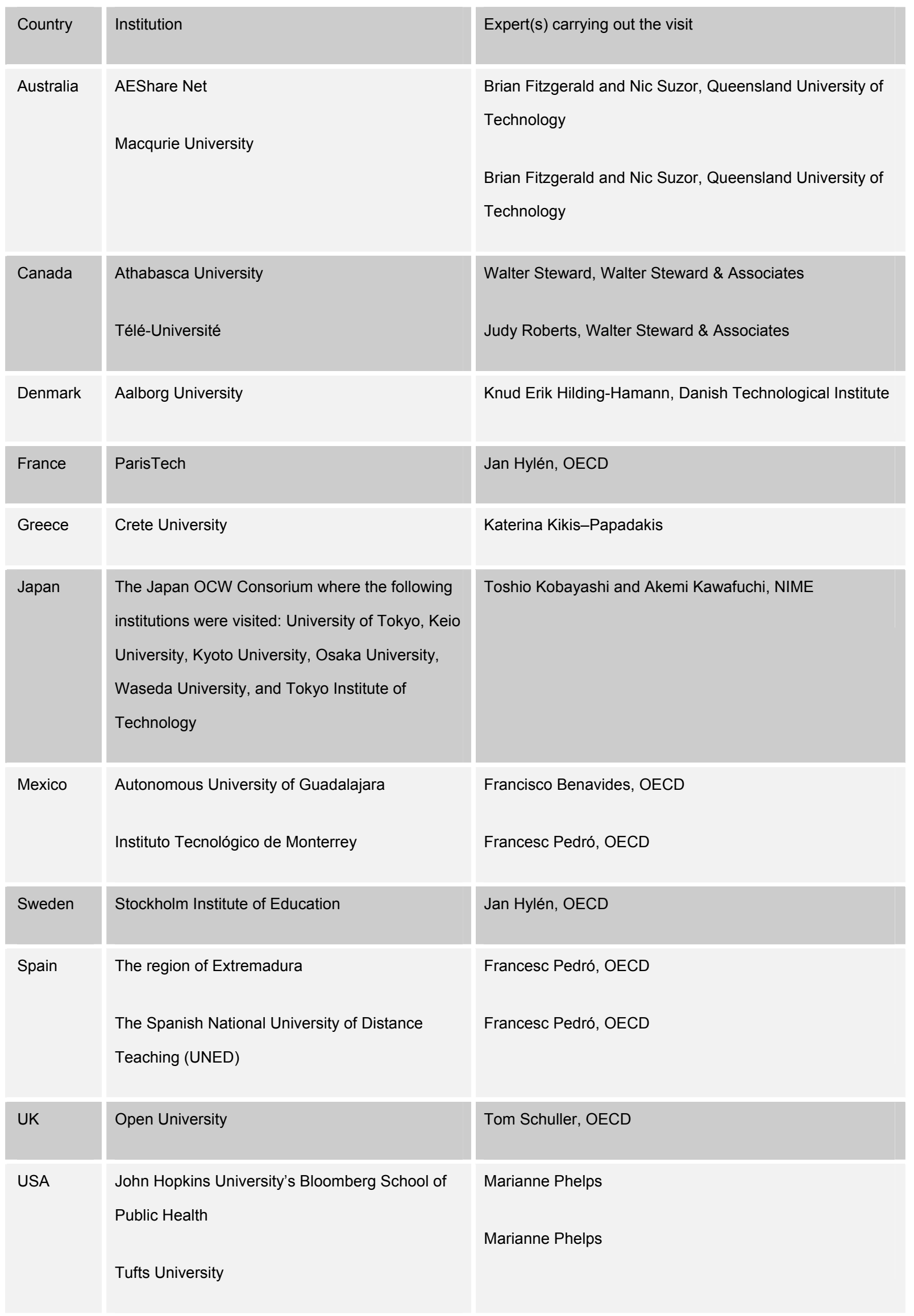




\section{第二章}

\section{オープンエデュケーショナルリソース(OER) とは何か - 概念的諸問題}

本章では、OERの概念について探求し、いかに“公開（open）”、“教育用(educational)”、 そして“リソース(resources)”という概念を理解するのかという問いをなげかけている。オー プンエデュケーショナルリソース（OER）という用語は、調整可能な蓄積されたデジタル資 産と、他の人々がその資産を制限されることなく利用することができるという利益を意味し ているとする。 
情報技術が容易に利用可能となるにつれ、教育分野においても、多くの発信元から莫大な 量のデジタルリソースが利用可能となってきている。高等教育機関に勤める教員の多くは自 身の担当する講義の中でインターネットを利用しており、このことは電子的な形態で利用可 能な講義コンテンツの量が増加しているということを意味している。それにもかかわらず、 つい最近まで、これらの教材（講義コンテンツ）のほとんどはパスワード等により所有者の システムの内側に閉ざされていた。OER ムーブメントは、このような障害を打ち破り、コン テンツを自由に共有できるようにすることを目指している。

Wiley が述べているように、“ラーニングオブジェクト”という言葉は、Hodgins により 1994 年に提唱され、教育者やインストラクショナルデザイナーの間に専門用語として急速に 広まった(Wiley, 2006a)。OER の歴史におけるラーニングオブジェクトの役割の一つは、「デ ジタル教材は多様な教授形態の下で容易に再利用されるべきである、という法則に則って設 計・作成される」という考えを普及させたことである（ラーニングオブジェクトに関する文 献の概要については、(Wiley, 2006c)を参照)。ラーニングオブジェクトが異なった状況・背 景の下でどのように利用または再利用されるのかは、レゴブロックや原子のイメージで記述 される。1998 年、Wiley は “オープンコンテンツ”という表現を考案した(Wiley, 1998)。こ の表現は、インターネット利用者の注目を集め、また、「オープンソースソフトウェア活動 の原理はコンテンツに対しても生産的に適用される」という考えを普及させた。さらに Wiley は、広範に導入されたコンテンツ用の公開ライセンス（Open Publication License）を初めて開 発した。

\section{1 オープンェデュケーショナルリソース (Open Educational Resources：OER) の定義}

オープンエデュケーショナルリソース（Open Educational Resources: OER）という用語は、 2002 年、UNESCO の主催で開催された協議会において、「利用者の共同体による非商用目的 の協議・使用・適応のための、情報通信技術により可能となる資料の公開提供」と定義され、 この時初めて使用された(Johnstone, 2005)。今日、最も広く用いられている OERの定義は、 「教員、生徒、自主学習者らが授業、学習、研究などの目的で自由に利用・再利用できる、 公開されたデジタル教材」というものである。これをより一層明確にするために、OER は以 下の要素を含んでいると言われている。

• ラーニングコンテンツ (learning content)：完全な講座（full courses）、コースウェア、 コンテンツモジュール、ラーニングオブジェクト、芸術品、論文。

・ ツール（Tools）：学習コンテンツの開発、利用、再利用、配信をサポートするソフ トウェア、コンテンツの検索・組織化、コンテンツ管理システム (CMS)、学習管理 システム (LMS)、コンテンツ開発ツール、オンライン学習コミュニティなど。

- 実装資料（Implementation Resources）：教材の公開、ベストプラクティスのための設 計原理、コンテンツの現地語化を推進するための知的所有権ライセンス。

前述の定義を詳しく見てみると、OERの概念は広範でありかつ漠然としている、というこ 
とが分かる。多様なコンテンツやオンライン教材は、講座、講座の一部分、芸術品、公開さ れた論文や参考図書、といったような資料に分類できる。時がたつにつれ、OER という用語 は、コンテンツだけでなく、コンテンツや学習を管理するソフトウェア、コンテンツ開発ツ ール、デジタル資料を公開するための標準規格・ライセンスツール（このような標準規格や ライセンスツールは、文化、カリキュラム、教授法などの観点からの要求に応じて、利用者 が資料を改良することを可能とする）といったものまで含むようになってきた。図 2.1 は OER の各要素について記述した概念図である。

OER の定義はより一層の改良を必要とする。このため、事務局は Ilkka Tuomi に学術論文 を発注した。本章ではこの論文を引用している。この論文の完全版は本プロジェクトのウェ ブサイト（www.oecd.org/edu/oer）において入手可能である。

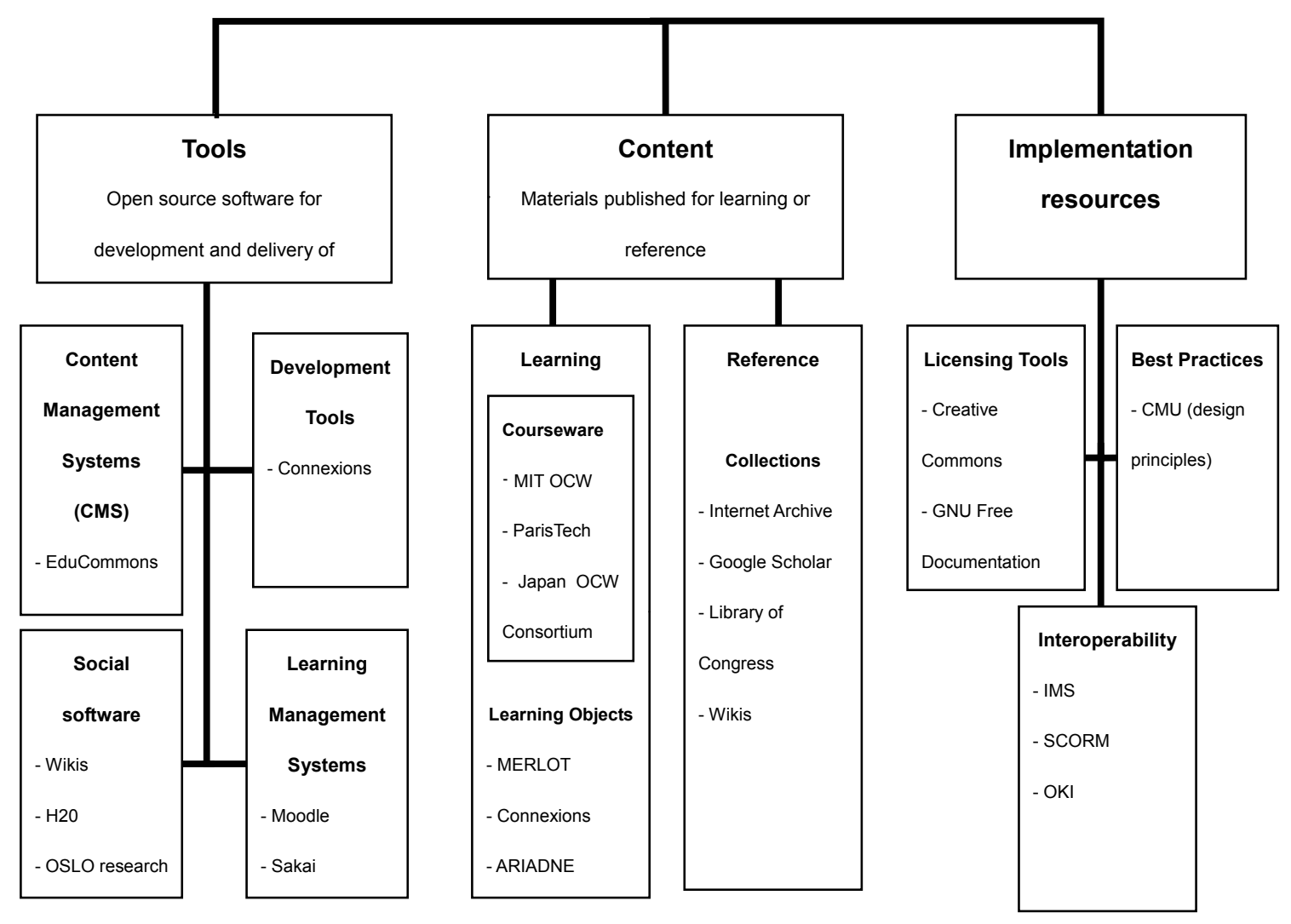

図 2.1 オープンェデュケーショナルリソース（OER）の概念図 (Source：Margulies， 2005)

\section{2 公開性 (openness)}

「公開性 (openness)」という言葉は、ある程度専門的な響きを持つ言葉であり、多くの人 にとって一見肯定的な連想を喚起するものである。Materu の用語では、90 年代が e-decade と呼ばれたのと同じように、現在の 10 年間が (open source、open systems、open standards、 open archives、open everything といった意味において)o-decade と呼ばれている(Materu, 2004)。 公開性の最も重要な二つの側面は、インターネット上での自由な利用が可能であること及び 
リソースを利用するための制約、すなわち末端の利用者に対する技術的、法的、価格的な障 害を可能な限り少なくすることである。OER との関係の下でこの用語（公開性）がどのよう に解釈されるべきであるかについて、いくつかの提案がなされている。Walker は「公開され ている」ということを「世界中の教員や学習者にとって利便性があり、効率的であり、価格 が手頃であり、持続可能であり、利用可能である」ことだと定義している。また、Sir John Daniel は「4つの A、寸なわち、アクセス可能であり (Accessible)、適切であり (Appropriate)、正 式に認可されたものであり（Accredited）、手頃な価格である（Affordable）」ことだと述べて いる(Daniel, 2006)。Downes は「公開性』という概念には、少なくとも、リソースの利用者・ 消費者にとって何ら費用がかからない、ということが求められるようだ」と主張しており、 さらに次のように続けている。

利用者からの何がしかの支払いを必要とするリソースが「公開されている (open)」と呼 ばれるべきか否かは、たとえその支払いが受信料、実物寄付、あるいはユーザ登録のよ うな単純なものであろうとも、不明である。支払いコストが低い（あるいは手頃である） 場合でさえ、利用者の側に何がしかのコストが必要となるならば、それは共有というよ りむしろ交換である(Downes, 2006)。

Tuomi は、「公開性」が重要となってくる3つの独立な領域を挙げている(Tuomi, 2006)。 一つ目は技術的特性、二つ目は社会的特性、そして三つ目はリソース自体の本質である。社 会的領域における公開性は、基本的に、期待される社会的便益及び人間の自由（利用する自 由、貢献する自由、共有する自由）に関連する倫理観念によって動機付けられている。これ らの自由がなぜ重要視されているかを理解するためには、当初から OER 活動がオープンソー スソフトウェアプロジェクトの成功に刺激されている、ということを知ることが重要である。 オープンソースソフトウェア (OSS)とは、人間にとって可読であるソースコードが、使用料や 手数料を支払うことなく複製・修正・再分配することを明示的に許可した著作権と共に公開 されているソフトウェアのことである。一般に、ソフトウェアは、ソースコードを利用・共 有可能であり、またその修正に貢献可能ならば、フリーである、あるいは「公開されている」 と考えられている。

これに対し、技術的領域における公開性は、技術的な相互運用性や機能性によって特徴付 けられる。オープン標準が重要なのは、異なるソフトウェアやアプリケーションを一緒に動 作させることを可能とするからである。オープン標準は、システム間のインタフェースを定 義しているが、システムコンポーネントの具体的な実装は「ブラックボックス」として取り 扱う。相互運用性の標準規格により、新しいシステムコンポーネントが、より大きなシステ ムの内部の要素として機能すると同時に、所有者のシステムコンポーネントに連結し得ると いう保証の下で開発可能となる。このため、工業関係者は標準規格化に多大な努力を傾ける。

技術的システムとしてのオープンソースシステムは、相互運用可能なモジュールにおける 上のような共存性（co-existence）という形態に勝っている。オープンソースシステムは、し ばしば、既存の相互運用性標準規格や洗練されたシステムインタフェースに強く依存してい るが、Tuomi はオープンソースシステムにより「深い相互運用性」を実現できると主張して いる(Tuomi，2006)。なぜなら、オープンソースシステムの開発者は、システム全体を見通す 
ことができ、システムの境界を越えてその修正を行うことができるからである。オープンソ ースシステムにおけるシステムコンポーネントは、内部構造や実装が隠蔽されているブラッ クボックスではない。それどころか、開発者は、新しいコンポーネントを開発する際の基盤 となるシステムコンポーネントの実装について学習することができる。オープンソースシス テムの構成要素は、透明な、あるいは公開されたボックスというように特徴付けられる。こ のため、オープンソースモデルは従来とは異なる開発力をもたらす。技術的インタフェース における公開性は、新しいコンポーネントを大きな労力を払うことなくより大きなシステム に組み込むことが可能となるような発展をもたらす。これに対し、オープンソースのアプロ 一チは、複合的な発展を引き起こすような集積をもたらす。

結論を言えば、公開性を制限するような技術的な制約が存在している。相互運用性の欠如 や技術仕様の入手困難さなどは、Tuomi によって提示されたその一例である(Tuomi，2006)。 パスワードでロックされた学習管理システム（LMS）の内部でのみ利用でき、外部利用者に は発見することのできない学習リソースもまたその一例である。

さらに、社会的、すなわち制度上や経済上の制約も存在する。著作権は、アクセスにかか る費用だけでなく、資料へのアクセスそのものも制限する。検索や学習に関連する倫理上の 標準規格もまた、例えばプライバシー等の理由のために、アクセスを制限する。社会的な制 約は、互いに衝突する緊張関係の間にバランスが存在するような、例えば、金銭を用いてよ り多くの資源にアクセスしたり、政治的な力で制度上の制約を変えたりできるような、複雑 な形態を呈する。

社会的な領域においては、公開性を複数の異なるレベルに区分できる。最も基本的な種類 の公開性は、アクセス及びアクセシビリティに関するものである。しかし、アクセシビリテ イは個々人の能力にも関連している。例えば、教材は自由に利用可能であるが、利用者には 理解できない言語で書かれている場合や、何らかの身体障害を有している一部の利用者にと ってはその教材が利用不可能になる場合などがある。World Wide Web Consortium が主導して いる Web Accessibility Initiative は、インターネットへのアクセシビリテイ、特に障害者や高 齢者にとってのアクセシビリティを広げようとする構想の一つである (第 7 章参照)。この種 類の公開性に対する実践的な基準は、リソースを発見・探索・学習寸る機会が差別なく存在 するかどうか、という点である。差別がないことの重要な側面の一つは、利用者がコストを かけることなくリソースを利用できることである。この点には、リソースを読んだり利用し たりするのに必要となるソフトウェアライセンスの手数料に代表されるような間接的なコス トだけでなく、リソース自体にかかる直接的なコストも含まれる。実際的な言い方をするな ら、リソースは、所有者のソフトウェアを購入する必要がないように、全ての利用者が開け るようなファイル形式で公開されるべきである、ということである。

社会的に制限された公開性の別の例として、アクセスが地理に関連している場合が挙げら れる。学習リソースの大部分は全世界的に利用可能であるが、リソースを利用する権利が特 定の国や地域に限定されている事例もある。ブリティッシュコロンビアの BCcampus プロジ エクトがその例である。カナダでは、学習リソースを地域内で公開的に利用可能にするため に、BC Commons と呼ばれるクリエイティブ・コモンズ・ライセンスの一種が開発されてい 
る。これでもまだ資料が公開されていると考えるならば、明らかに過度の地理的制限が行わ れてはいないが、厳密な線引きは難しい。BC Commons を擁護する主張としては、「これ（BC Commons）は、個々の大学教員が自身のリソースを広く世界に共有することへの大きな一歩 であり、小さい範囲（地域）から始めることで、大学教員らはより自発的に OER 活動に参加 することになるだろう」というものがある。もしこの主張が正しいなら、この種の社会的 (空 間的）公開性と利用可能な資料の量との間には重大なトレードオフが存在することになる。

第 5 章においてより詳しく説明するが、リソースの著者あるいは開発者は、リソースがど のように利用されているのかを特定するためにライセンスを用いるだろう。現在、最も認知 され利用されている公開ライセンスは、多くのオプションを付けることができるクリエイテ イブ・コモンズ・ライセンスである。最も制限の強いバージョンでも、利用者がその旨を明 記して著者または開発者に連絡すれば、教材をダウンロードして他者と共有する権利は認め られるが、その内容を何らかの形で変更したり商用的に利用したりする権利は認められてい ない。その他のバージョンのクリエイティブ・コモンズ・ライセンスの場合は、利用者は開 発者からより独立している。このことは、「公開されている」ということは「コストがない」 ということを意味する一方、「条件がない」ということを意味するわけではない、ということ を示している。

さらに Tuomi によれば、より高レベルの公開性は、リソースを修正して再パッケージし、 価值を付加する権利・能力に関するものである(Tuomi, 2006)。この種類の公開性の前では、 「ユーザ」と「プロデューサー」という伝統的な区別が不鮮明になってくる。「ユーザ・プロ デューサー (user-producer)」という単語がこの役割の不鮮明さを強調するために用いられる こともある。しかし、デジタルリソースの改良・修正を可能とするためには、その教材が、 文章の一部や図表などのメディアをコピー\&ペーストできるようなファイル形式で公開され ている必要がある。これは、編集不可能な形式、例えば Flash (.swf) や Adobe Portable Document Format (.pdf) のような形式では、高レベルの公開性は満たされない、ということを意味して いる。より公開された形式としては、HTML、ODF、RTF、SVG、PNG などが挙げられる。 一方で、これらのファイル形式は利用するのがより難しいため、そのためのスキルを持って いない人を排除してしまう。

上記の議論における高レベルの公開性は、Mako Hill と Möller により創始された Freedomdefined.org と呼ばれる Wiki 上でフリーに利用可能なコンテンツの定義に類似してい る。この定義によれば、「フリーな」著作物は次のような点で自由である。

・その著作物を学習し、それにより得た知識を適用する自由

・情報や表現の全体または一部をコピーして再分配する自由

• 修正など何らかの変更を行い、変更したバージョンのコピーを公表する自由 
Wiki にはこの定義を満たすと考えられるライセンスのリストが含まれている。 この定義の下で「フリーである」として認識されるためには、ライセンスは次のような自由 を許可していなければならない。

・ 情報を学習・適用する自由：ライセンスは、情報を分析・修正・適用する権利を制 限寸るような条項により制約されてはならない。例えば、ライセンスは、リバース エンジニアリング（デバイスやオブジェクト、あるいはシステムの構造・機能・動 作を解析することで、その技術的原理を発見するプロセス）を制限してはならず、 また、著作物から何らかの形で取得される知識を適用することを制限してはならな い(この条件は上で議論した最も基本的なレベルの公開性に対応する)。

・コピーを再分配する自由：コピーは、より大きな著作物の一部やその集積などの形 態で、あるいは独立に、販売・交換・寄贈されてもよい。この時、コピー可能な情 報の量にはいかなる制限もあってはならない。さらに、情報が誰によって、どこで コピーされるかに関しても、制限があってはならない（この条件は、上で議論した 公開性の範囲を超えている。なぜなら、上の議論では、第三者による資料の商業的 利用を禁止する条項を有するライセンスの利用が排除されていないからである)。

・修正バージョンを公表する自由：誰もが著作物を改善できるようにするために、ラ イセンスは、著作物を修正する意図・目的がいかなるものであっても、そのように 修正されたバージョンを公開する自由を制限してはならない。ただし、これらの基 本的な自由やその権限に対する要求を保証することが目的の場合には、何らかの制 限が適用されてもよい（一つ前の条件において述べたのと同様の理由により、この 条件は上で定義された公開性の範囲を超えている)。

結論を言えば、Mako Hill と Möllerにより提唱された自由の定義は、Tuomiによって記述さ れた全てのレベルの公開性(Tuomi, 2006)の範囲を超えており、多くの既存の OER がフリーで はないと定義していることになる。このため、事務局は、Tuomi による公開性の定義に従う。

\section{3 教育用 (educational)}

「教育用 (educational)」という言葉の意味も明確にする必要がある。この言葉は、フォ ーマルな教育環境で用いることを意図して生産された教材のみが含まれる、ということを意 味するのだろうか。もしそうならば、ニュースの記事のように、小中高校や大学以外の機関 において生産されながら、フォーマルな講座で用いられている資料や、逆に、小中高校や大 学において生産されながら、外部のノンフォーマル学習やインフォーマル学習で用いられて いる教材などは、含まれないことになる。

Downes は、「学習はフォーマルな環境を超えて拡張しているのだから、資料が教育用のもの であるか否かはアプリオリに規定される必要はなく、従って、ノンフォーマルな環境で用い られている資料もまた OERの一例であると言える」と主張している(Downes, 2006)。

一方で、OERが公開されるということは、その概念（educationalの意味）は不明瞭で曖昧な ままである、ということを意味する。一つの代替案として、実際に授業や学習のために用い 
られた教材のみを考慮する、というものが考えられる。この考えの利点は、資料が教育用の ものであるか否かに関するアプリオリな規定を作ることを避けられるという点である。欠点 は、資料が実際に学習のために用いられたかどうかを確認することは、ノンフォーマル学習 やインフォーマル学習の場合には難しいという点である。

教育において OER を利用する目的は、当然、学習というものを強化すること、希望的には、 個人と社会の両方が理解力や活動力を高められるような学習を実現することである。

OER がフォーマルな学習環境の外側、すなわちノンフォーマル学習やインフォーマル学習の ためにも用いられるということは、よく知られた事実である。OERのこの役割を確認し強化 することは重要であり、「education」という単語を「learning」に変換して「Open Learning Resources」とすべきだ、という主張がなされることもある。

事務局は、ノンフォーマル学習やインフォーマル学習における OER 利用の重要性を損なう ことなく、既存の専門用語を用いることを選択した。これは次のような実際的な理由による。 すなわち、現在、OER 活動は急速に発展しており、OERの名の下で新しい事象を学ぶ人々が 増えている、という状況で専門用語を変更することは思慮が足りないと思われるからである。

\section{4 リソース (Resources)}

辞書上では、「リソース (Resource)」という単語の意味は、「効率的に機能するために利用 できる物質や有価材の備蓄・供給」と定義されている。備蓄を切り崩すことなく利用したり コピーしたりできるデジタル資料は、再生可能なリソースである。Tuomi は、学習者の視点 から見ると、標準的な辞書における「リソース（Resource）」の定義はうまく機能している、 と主張している(Tuomi, 2006)。教育的・民族的な研究の結果、学習者は学習のために多数の 様々なタイプの「有価材 (asset)」を動員できる、ということが分かっている。また、学習者 は、学習目的であることが意図されていない資料を独創的に用いることによっても、学習寸 ることができる。同様のことが教員の視点から見ても言える。すなわち、教育リソースとは 「学習経験を養い組織化するために用いられるあらゆるもの」である。

コンピュータを活用した授業・学習の場合には、リソースは、しばしば、デジタルリポジ トリに蓄積されたテキスト、音声、ビデオファイル等の学習コンテンツとして理解される。 一部のケースでは、この見方は問題がある。例えば、話し合いや会議において異なる種類の ソーシャルソフトウェアが用いられており、それが学習過程の一部として役立てられている ケースなどである。このようなケースでは、ソーシャルソフトウェアは、学習源を構成する 要素というよりはむしろフロー、あるいは自動的に生成されるサービスである。

Tuomiによる単純化された議論においては、「公開性は、社会的特性や技術的特性に関連す る側面であるだけでなく、リソースそのものの側面でもある」と結論されている(Tuomi, 2006)。 オープンリソースは、他者が享受する部分を減らさずに享受できるサービスを生産するリソ 一ス (多くの場合それはデジタル資料となる)、というように記述することができる。経済学 的な見方をすれば、リソースは公共財であるということである。しかし、リソースの中には、

「他者が既に利用している状況であっても利用できる」だけではないものもある。場合によ 
っては、より多くの人に利用されればされるほど、より価值の高まるようなリソースもある。 その一つがフリーに利用できるオープンソースソフトウェア (OSS)である。その効果は、電話 や e メールなどのネットワークサービスと同様であり（これらのネットワークサービスの全 てがフリーに利用できるわけではないが）、Metcalf の法則と呼ばれている。より多くの人々 がこのようなサービスを利用すれば、そのサービスはよりアクセス寸る価值のあるものとな る。このような “open fountains of goods”とも呼ばれるものは、やがて別の種類のオープン リソースを形成するだろう。図 2.2 は、公開性の様々な側面を要約したものである。

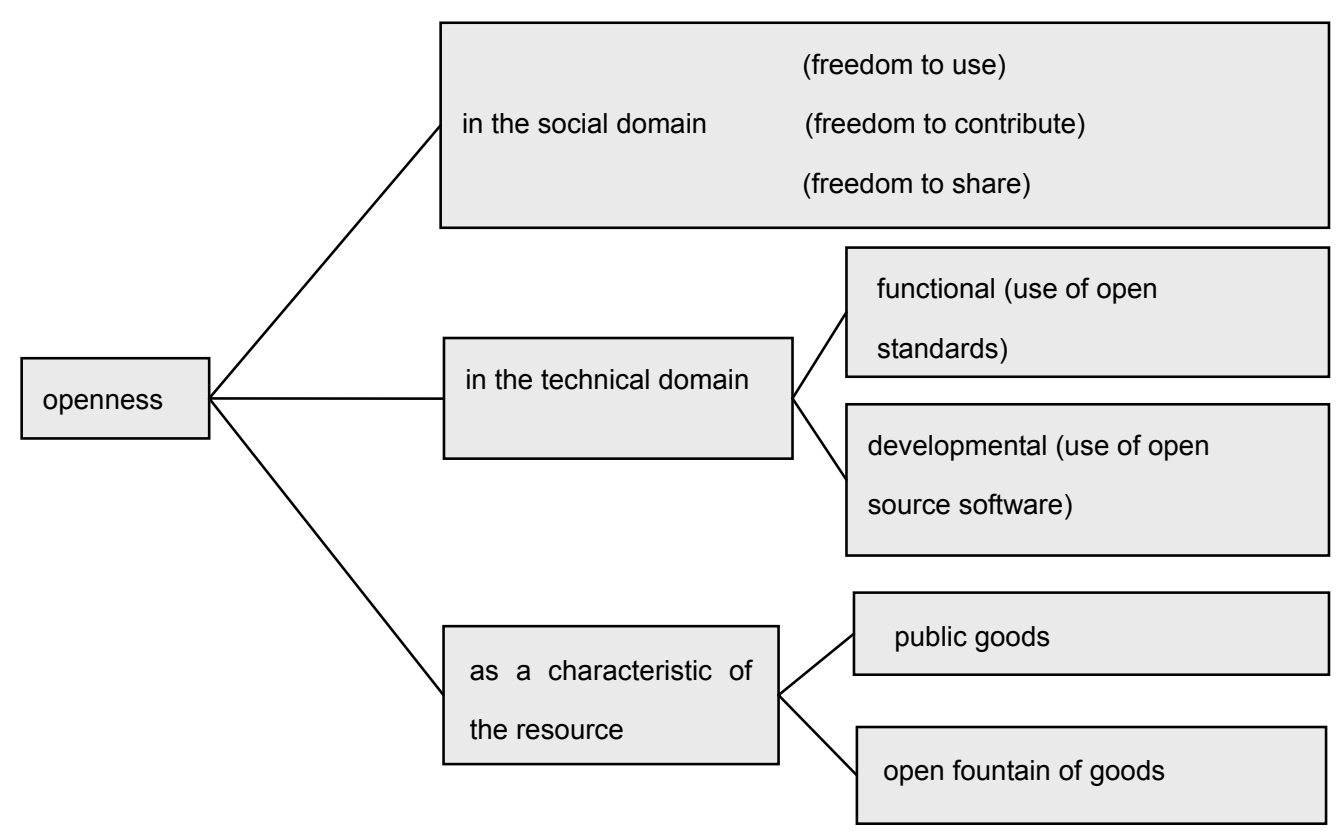

図 2.2 公開性の側面

\section{5 まとめ}

公開性というものは、多様な領域において多用な形態で存在している。また、多くの構想 が、最も基本的なレベルでの公開性しか提供していないにもかかわらず重要であることから、 前述のように導入したレベルの概念は規範的でなく記述的である。これを総括すると、ここ では、「オープンリソース」とは次のようなものであると論じられる。

・享受された際にサービスを生産する能力が減退しないようなサービス源であり、

・誰に対しても差別のないアクセス性を提供できる、

・適応・修正・共有が可能な資料である。

加えて、Tuomi は、「どのような条件の下で貢献しうるのかを明確にする必要がある」と主 張しており、さらに、「その際の条件は、1942 年 Robert Merton が提唱した“地域主義性 (communalism)”、“普遍性 (universality)”、“無関心性 (disinterestedness)”、“独自性 (originality)”、 “懷疑性（scepticism）”の 5 原則（頭文字をとって CUDOS と略される）に従うべきである」 
と続けている。しかし、人々がリソースを共有し再利用する理由や必要性は実に多様であり (「ある者にとってのガラクタは、別の者にとっては金である」ということである。詳しくは 第 4 章を参照)、上記は過度な条件であるように思われる。

結論を言うと、OER の明確な定義として、「教員、生徒、自主学習者らが授業、学習、研 究などの目的で自由に利用・再利用できる、公開されたデジタル教材」という定義を与える ことができる。我々がこのように大まかに考えているリソースは、「他者が享受する可能性を 制限することなく享受できる、蓄積された有価材」である。これはすなわち、OER とは「公 共財であり、かつ利用されることで価值が拡大寸る資料（open fountains of goods）である」 ということを意味する。さらに、「公開されている」ということは、「資料が差別のないアク セス性を提供するものである、あるいは、誰もが共有し貢献できるものである」ということ を意味する。

最後に、OERの事例はまだ初期の実践段階にあり、技術の発展に伴い、その概念に明確な 定義を与えることは不可能である、という観念は急速に変わりつつある、ということを言及 しておく。数年の後に、OERの概念をどのように定義すべきか、という地点に再び戻ってく る必要に迫られるだろう。 


\section{第三章}

\section{誰が関与するのか -OER 動向の位置付け-}

本章では、OERの利用者と制作者の位置付けをしている。はっきりした統計はないが、OER ムーブメントは、プロジェクトの数、関与する人間と利用できるリソースの数において拡が りをみせている。OER は、ほとんどのリソースはいまのところ先進諸国で制作されているが、 グローバルな展開をしている。OER ムーブメントは、トップダウンとボトムアップの両方で 成長しており、新たなプロジェクトが機関レベルで発足し、また個々の教師と研究者は率先 して OER を利用し制作している。あらゆる種類の機関が、そして全ての領域の研究者と教師 が関与している。 
OER の動きはまだ早期のものであるが、その試みの数は急速に増えている。大規模な機関 による試みと並んで、非常に多くの小規模な活動が始められている。Wiley(2006a)によると、 2006 年冬の時点で高等教育(post-secondary education)における OER の動きの大まかな概要は 次のようになっている。

現在 300 を超える大学から 3,000 以上のオープンアクセスコース (オープンコースウェア : OCW）が提供されている。

• アメリカでは、1,700 講座が 7 大学、MIT、Rice University、John Hopkins Bloomberg School of Public Health、Tufts University、Carnegie Mellon University、University of Notre Dame、Utah State University からなるプロジェ クトによって提供されている。また、2006 年 10 月には Yale が OER の試み を2007 年秋に開始する予定であることを発表した。

• 中国では、750 講座が China Open Resources for Education(CORE)コンソーシ アムのメンバーである 222 の大学によって提供されている。

・ 日本では、400 を超える講座が日本の OCW コンソーシアムによって提供さ れており、そのメンバーは 2005 年 5 月の 7 大学から 2006 年 10 月には 19 大学にまで増えた。

・ フランスでは、約 100 単元からなる 800 の教育資料が ParisTech OCW プロ ジェクトの 11 大学によって提供されており、その数は 2007 年の間に 2 倍 になると予想されている。

その他の試み :

- Open University in UK では 5,400 学習時間のコンテンツをオンラインで提供 する OpenLearnの試みを2つの方法で開始した。LearningSpace は学習のた めの教材を提供し、LabSpace ではコンテンツのダウンロード、改変、修正、 再利用を行うことができる。

・オーストラリアの AEShareNetでは約 20,000 オブジェクトが教育利用のため に無料で利用できる。

・ ヨーロッパでは、ロシア、トルコを含む 9 カ国からなる最大の distance teaching universities が Multilingual Open Resources for Independent Learning(MORIL)と呼ばれるプロジェクトを始めており、カリキュラムを充 実するため、そして自由に利用できる講座数と言語の両面からトレーニン グの提供を改善するために教材の共有が行われている。

この状況は急速な進展により常に変化している。より多くの OER プロジェクトがオースト ラリア、ブラジル、カナダ、キューバ、デンマーク、ハンガリー、インド、イラン、アイル 
ランド、オランダ、パキスタン、ポルトガル、ロシア、南アフリカ、スペイン、スウェーデ ン、タイ、イギリス、アメリカ、ベトナムなどの教育機関で発足している。

\section{Box 3.1 MIT の OCW 構想}

\section{経緯}

2000年春、MITの教育工学委員会[Council on Educational Technology]は「最新の争点や新興分 野の十分な知識を目標市場に供給する[オンライン教育]モジュールを作り上げ提供する方法 を検討するための提案を行う」ためのチームを任命した。その当時多くの組織が新規事業に 着手し市場シェアと資金調達を競っていた。MITのチームは「財政的に実行し維持すること が可能」であることを確実にするため、この事業で収益を得る案を考えることから始めた。 コンテンツを無料で提供するという案はOCWの開始間際まで議論されることは決してなか った。

OCWの決定前に、チームは3つの主要な研究を行った。チームのメンバーはe-Learningに携わ る教育機関と企業、両方の組織にインタビューを行った。彼らは市場研究を継続し、ビジネ スモデルを作成した。そして彼らは現在のMITにおけるe-Learningプロジェクトの価值を判断 したのである。研究によりオンライン事業が5年で財政的に独立するであろうことを提案する モデルが得られた。この見解は同様の試みから日々得られる多くの報告とは非常に対照的で あった。この時点でチームはMITにおけるe-Learningプロジェクトの評価に取り掛かり、2つ の重要な見解をもたらした。一つ目は、どの教職員[faculty]の回答者も例外なく授業[teaching] の質を改善するためにオンライン教材を作っていたということである。二つ目はほぼ例外な く彼らの著作物[work]に対して金銭的な対価を受け取っていなかったということである。こ れらのインタビューによって回答者らが教職員の責任の一部として授業を継続的に改善する ことに中核的に献身していることが明らかになった。

2000年10月、チームは全ての見解を考慮し、講座の教材を無料で公にオンラインアクセスで きるようにするという考えに至った。これはMIT教育の知識を提供することと等しくはない が、大学のビジョンについて強いメッセージを送ることになるだろうと考えられた。すなわ ち、インターネット経済時代において、MITはe-Learningを含む学習を財務利益以上に重視す るということである。学長[provost]、総長[university president]及び学内の教職員で行われた会 議においてこの考えに対する支持は強く、2001年4月にOCW公示への道が開かれた。MITの 各教授の参加は完全に任意であったが、これまでに $75 \%$ の MIT教職員がOCWに貢献している。 また、49\%は2つ以上の講座に貢献している。(続く) 


\section{Box 3.1 (続き) MIT の OCW 構想}

スタッフ及び予算

OCWは収益体系を必要としないが、その実現には費用がかかる。2000年にMITで提供された全講座の オンライン教材を製作するために、10年にわたって8500万米ドルを要したと推定される。OCWの発表 時には、財政的問題は解決されていなかった。ヒューレット財団やメロン財団などからの補助金により この試みは実現したのだ。現在MIT OCWでは8名の中心的スタッフ、5名の出版マネージャ[publication managers]、4名の製作チームメンバー[production team members]、2名の知的所有権調査員 [intellectual property researchers]と10名の部門連携[department liaisons]を含む少なくとも29名のスタッフが雇用され ている。2名の知的所有権調査員は毎年6000部の第三者の所有するコンテンツの権利問題を扱っている (例えば、MIT OCWのウェブサイト上の教材の使用権利の申請)。部門連携は共に働く教職員を特定し、 MIT OCWのために彼らの関係をやり繰りする。

また、MIT OCW は付加サービスへのアクセス増加のため Sapient、Microsoft、Maxtor、Hewlett-Packard、 Akamai、NetRaker といった多くのベンダーと契約を結んでいる。これらのベンダーはこの試みに対して 各々付加サービスや製品を提供している。

MIT OCW プロジェクトの年間予算は 2007 年から 2011 年までを通じて平均で 430 万米ドルを少し上回 る程になる。その大半はスタッフ (年 210 万米ドル)、技術 (年 100 万米ドル)、そして契約サービス (年 56 万米ドル) に割り当てられている。年平均 430 万米ドルの費用に対し 1 年で平均 540 講座が作 られているため、1 講座につき平均で 1 万米ドル弱の費用がかかっていることになる。

\section{教材及びユーザ統計值}

MIT OCWでは完全な映像と音声の講義の少量のよりぬきだけでなく、講義ノートや問題集、シラバス、 文献リスト、シミュレーションも提供している。MITの約1,800講座のうちの1,550講座は、2006年秋の 時点で既に公開されている。加えて、OCWでは以前公開されていた133の講座の更新版を公開した。

MIT OCW 自身の評価によると、2004 年 10 月から 2005 年 9 月の期間に OCW コンテンツヘのビジタ 一が 850 万人にのぼり、これは年次増加 56\%になるという。これは MIT とミラーサイト、両方へのビ ジターを含んでいる。MIT OCW のサイトは現在、世界中 70 以上の地域に置かれている。OCW の教材 はオフラインで広く二次配布されている。ビジターの 18\%は OCW の教材のコピーを他者に配布してい るのである。教育者[educator]の 46\%はサイトコンテンツを再利用している。そのうち $30 \%$ 学生に印 刷されたコピーを配り、24\%はデジタルコピーを渡している。OCW の利用は電気工学、コンピュータ サイエンス、数学、経営学、物理学、経済学、機械工学といった MIT が認められている学科に集中し ている。

Sources: http://ocw.mit.edu , Lerman and Miyagawa (2003), Wiley (2006b), Carson (2006a) 
OCW モデルが時に双方向性に欠ける PDF 形式による静的な講義ノートしか提供しないこ とで非難される一方、MIT OCWによるユーザ評価では、ユーザの 97\%が彼らの利用目的に は PDF 形式が適していると考えていることがわかった(d'Oliveira，2006)。さらに、OECD ケ ーススタディにより OCW モデルが普及していることが示された。Tufts University では講座 の解説、シラバスへのリンク、スケジュール、そして通常完全な講義ノートを備えた全ての OCW 講座のためのウェブポータルを構築している (Phelps, 2006b)。また、これには時に講義 用スライドが含まれる。大学では既存のコンテンツを新たなコンテキストで再利用できるよ う 40 万部以上のコンテンツを扱うことのできるオープンソースソフトウェア (OSS)によるコ ンテンツ管理システム(CMS)の開発も行った。典型的な講座管理システムが独自の方式で講 座を提供するのに対し、このシステムはキーワード、ナゲッツト、トピックセンテンスで索 引が付けられたメタデータを持ち、学生のために豊富な参考文献を提供する全講座にわたる コンテンツの統合を可能にしている。最新の研究へのアクセスも提供されている。10名のイ ンターネット上の参加者によるケーススタディを取り入れることも計画されている。講座を 構築時にコンテンツ管理システム(CMS)で提供されるツールを使用した後では、講座を OCW で利用できるようにすることが技術的に容易になる。主要な障壁はデータベース内の第三者 の教材使用に関連して起こる著作権問題である。事実、これは時には著作権問題のため OCW の講座の教材の完全なオンライン化ができないかもしれないということを意味する。これは スタッフが頻繁に豊富な出典を挙げる健康科学の講座においてはとりわけ顕著である。なぜ なら公的に利用可能なサイト内に全てを掲載するために必要な全ての承認と譲渡を得ること が困難だからである。

Mulder (2006)は、Open Universities in Europe (OpenLearn, OpenER and MORIL)によって始め られた 3 つの試みから生まれた学習リソースは OERの「第 2 の波」を象徴していると論じて いる。対面講義を想定しない遠隔手法によって教える大学(distance teaching universities)によっ て作成され、主に生涯学習者を対象としているため、教材がとりわけ自己学習に適している というのである。

Universia のスペイン語、ポルトガル語翻訳、China Open Resources for Education (CORE) の 簡体中国語翻訳、Opensource Opencourseware Prototype System (OOPS) の繁体中国語翻訳、 Chulalongkorn University のタイ語翻訳を含め高等教育に基づいた教材を多言語で利用可能に する計画を進めているプロジェクトは多い。このような翻訳プロジェクトは現在オープンコ 一スウェアスタイルの全講座のうちの 9～10\%に当たるが、OCW の講座の全アクセス量の約 $50 \%$ を受け取っている。これは東アジア及び南アジアにおけるこれらの講座の需要を明らか にしている。100 を超える世界中の高等教育機関及び関連組織がオープンコースウェアコン ソーシアムを組織しており、それらはオープンコースウェアを通して教育の推進と人々のグ ローバル化を行うという構想を持って共通のモデルを使用している。加盟機関は機関の名の 下、合意されたオープンコースウェアの定義を満足する形式で最低 10 講座の教材を公開する ことを表明しなければならない。それは「講座としてまとめられた高品質な教材の無料で公 開されたデジタル出版物」なのである(Carson, 2006b)。オープンコースウェアコンソーシアム によって提供された教材の急速な増加を図 3.1 に示した。 


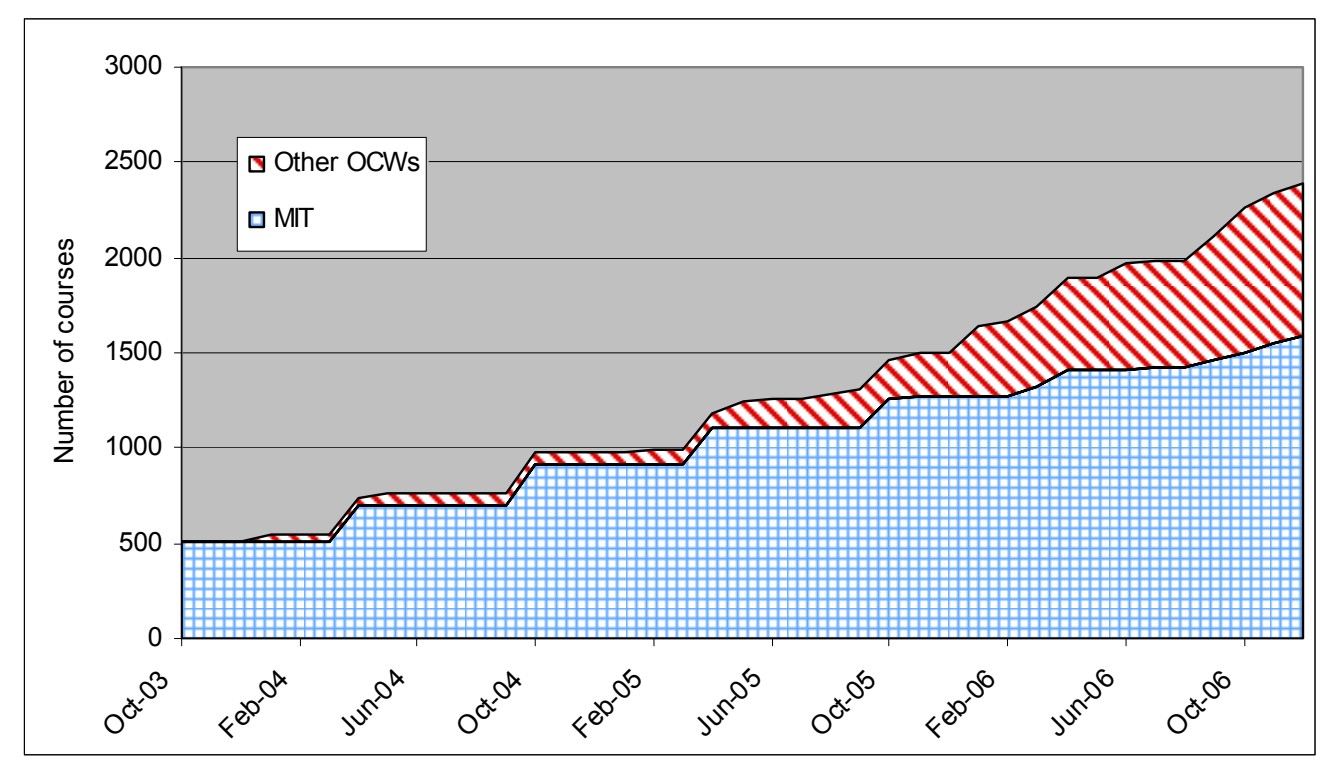

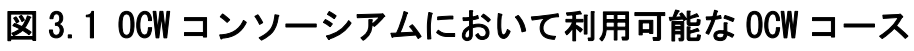

(2003 年 10 月 2006 年 12 月 : Source MIT)

論文や個々のカリキュラム、モジュール、シミュレーションといった利用できる非講座の OER の数も急激に増加している。Math World は 12,600 の項目を含んでいる。2007 年 1 月の Rice's Connexions プロジェクトでは研究ユニットや全講座をうまく組み合わせるために 3759 以上のモジュールと 199 以上の講座が利用できる。University of California, Berkeley では無料 の Google ビデオを通じて全体で 250 時間を越える、150 以上の講義、シンポジウムを提供し ている。Textbook Revolution は著作権問題を解決した 260 の無料で利用できるテキストへの リンクが含まれている。MERLOT では約 15,800 の資料が提供されている。Alliance of Remote Instructional Authoring and Distribution Networks for Europe (ARIADNE) Foundation for the European Knowledge Pool ではいくつかのネットワーク及びリポジトリにおけるリンクと横断 検索が提供されている。UNESCO 国際教育企画研究所（IIEP）はポータル、リポジトリ、オ ープンコンテンツプロジェクトへのリンクがある「OER の役立つ資料」のリストを含むWiki を持っている。狭義の OER でさえ、プロジェクトの数を挙げるよりも利用できるリソースの 量を推定することの方が困難である。上に挙げたものはプロジェクトを通してアクセスでき るリソースの一部であり、さらに多くのものを Google や Yahoo!のような検索エンジンで見 付けることができる。

現行の OER プロジェクトの数を正確に推定することは現時点では不可能である。提供でき るのは異なるリポジトリの予備的類型論である。既に触れたとおり、活動には大規模なもの もあれば小規模なものもある。また、機関によるプログラムやコミュニティによるボトムア ップ型の活動といった異なるプロバイダを区別することが可能である。どちらにしても図 3.2 に示すように、連続体を形作るあらゆる種類の中間モデルが存在する。 


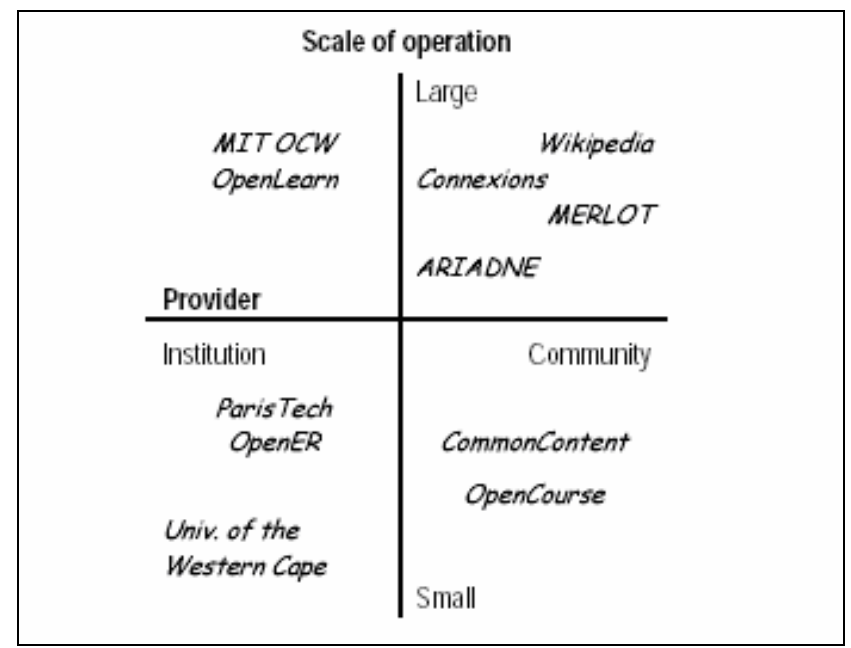

図 3.2 OER プロバイダの分類

図の左上は、大規模で機関主導の試みが見られる。MIT OCW や Open University in UK の OpenLearn がよい例である。これらはどちらも資金的支援を受けているという点では大規模 である。OpenLearn もまたダウンロード, 改変、共有のための試験的領域を提供してはいるが、 全ての教材をスタッフ自ら作成しているという意味ではこれらは完全に機関主導である。図 の右上は、非機関主導の大規模な事業が位置する。Wikipedia が最もよい例であろう。Wikipedia はインターネット上で真に成功したもののひとつであり、大規模コミュニティからなる事業 のよい例である。Wikipedia は 10 の主要な言語で 350 万を超える記事を提供しており、コン テンツの面では大規模である。しかし、有志による投稿に依存した試みであることから考え られるようにスタッフの観点で見ると小規模である。他の例として MERLOT や Connexions が挙げられるであろう。図の左下には、小規模ではあるが機関主導の試みとして 3 つ例が 挙げられている。南アフリカの University of the Western Cape では「無料コンテンツ及び無料 公開オープンコースウェア戦略」を開始した。Open University of Netherlands によって始めら れた OpenER ではノンフォーマル学習者のためのオランダ語による 400 時間分の教材が公開 された。最後に、図の右下には小規模でコミュニティ主導の試みが 1 例挙げられている。 OpenCourse は「オープンで再利用可能な資産 (アニメーション、シミュレーション、モデル、 ケーススタディなど）の作成を共通の目的とした、教師、研究者、学生の共同プロジェクト」 である。他の例として Creative Commons からのライセンスに基づいて利用可能なものや Public Domain のものに関する情報のリポジトリである Common Content がある。

考慮すべき第 3 の側面はリポジトリが単一の専門分野の資料を提供しているのか多くの専 門分野にわたっているのかということである。Stanford Encyclopaedia of Philosophy や Health Education Assets Library (HEAL)のように単一の専門分野の事業もあるが、現時点では多くの 専門分野にわたるやり方がより一般的なようである。 
Multimedia Educational Resources for Learning and Online Teaching (MERLOT)は分散学習[distributed learning]のために California State University Center が 1997 年に作成し、提供している。MERLOT はアメリカの国立科学財団[National Science Foundation]の融資によるプロジェクトをモデルとして、当初は Apple Computer をスポンサーにしていた。

2000 年 12 月の時点で、MERLOT には主に北アメリカの 24 の高等教育パートナー及び関連会社[affiliates]、10の電子 図書館、そしていくつかの会社パートナーがあった。教職員、スタッフ、司書[librarians]、運営管理者[administrators]、 学生といった世界中の 40,600 名を越えるメンバーで構成されている。MERLOT は他の場所に置かれた教材へリンク しているため、「リポジトリ(repository)」というよりはむしろ「リファラトリ(referatory)」である。教材は講義やケー ススタディ、蔵書参照教材[collections reference materials]、ポッドキャストだけでなくシミュレーション、アニメーシ ヨン、チュートリアル、演習[drills and practices]、試験[quizzes and tests]まで網羅している。また、15の専門分野コミ ユニティ、2 つのパートナーコミュニティ、そして 1 つの作業員[workforce]コミュニティがある。コミュニティポー タル[community portals]では持続的な専門能力開発のため、メンバーに模範的授業方針専門組合[exemplary teaching strategies professional associations]、論文誌、会議、その他の資料についての差別化された情報を提供している。

オープン教育資料の数少ないプロバイダのひとつとして、MERLOT は学術誌に酷似した専門家による評価プロセス [peer review process]を使う。専門分野コミュニティには以下の一般的な評価基準を用いる Editorial Board がある：

- コンテンツの質 - 情報の通用性、妥当性、正確性、そのコンテンツが明瞭かつ簡潔で学術的なもの[informed by scholarship]か、コンセプトが十分明らかにされているか、どれほど適応性があるか、コンセプトが十分に統合、 要約されているか、など。

- 授業ツール[teaching tool]としての潜在的有効性 - 教材に学習方針が明確に記されているか、それは前提知識を 特定しているか、効果的か、コンセプトは徐々に拡充しているか、事前のコンセプトに基づいて進められてい るか、コンセプト間の関係が明らかにされているか、など。

- 使いやすさ - 教材は使いやすいか、明瞭な説明があるか、興味をそそるものか、視覚的魅力があるか、双方向 性があるか、効果的なナビゲーション手法が使われているか、全ての要素が予定通り機能しているか、など。

各専門分野固有の Editorial Board の查読者は皆、テストケース[test case]を作るため構築された方法と提供された枠組 みに従い評価を共有し比較する。これらのテストケースは専門分野の全教材に適用される評価指針/基準を作成するた めに使われる。各 Editorial Board では評価手続きがその専門分野の残りの教材に対して評価手順を実施する前にその 評価の評定者内の信頼性[inter-rater reliability]を確立する。審査チームは通常 2 段階の審査過程を使う。まずその教材 が審査する価值のあるものかどうかを立証し、その後でより鋭い審査が 2 人の查読者によって個別に行われる。もし 2 人の査読者の評価に著しい相違がある場合には、Editor または Associate Editor は第 3 の査読者に教材を査読させる。 統合、合成された評価が 2 つの別の報告書から作られ、これによって MERLOT のウェブサイト上に掲載される。

査読は時にユーザのコメントや評価により補足される。2006 年冬、MERLOT は 15,500 以上の資料へのリンクを含ん でいる。

Source: www.merlot.org and Merlot (2006) 


\section{1 OER の用途、ユーザ、プロデューサー}

利用可能な全 OER を実際に誰が使い、誰が製作しているかについて多くのことは知られて いない。もちろん、様々な大学のオープンコースウェアプログラムのような機関主導のプロ ジェクトでは教材作成に自身のスタッフを起用しているし、MIT のようにそれらの一部では その利用者を継続的に見積っている。けれども、総じてユーザとプロデューサーが誰である かについてはほとんど知られていない。この不足を是正するため、OECDプロジェクトは2006 年春にウェブベースの 2 つの調查を開始した。1つは機関を対象としたもので、もう1つは 個々の教員及び研究者を対象としたものである。1,800 通以上の電子メールが 30 の OECD 加 盟国の大学に送られたが、当初の回答数は非常に少なかった。電子メールは学長/大学副総長 のオフィスに送られた。このひどい結果は OER がまだほとんど草の根の事象であることの表 れかもしれなかった。機関の管理職が研究グループ内で、あるいは各教職員メンバーによる プロジェクトとして起こっている活動に関与せず、気付いていないのである。

個人調査では世界各地にわたる 49 の異なる国々から 193 人の回答があった（表 3.1 及び図 3.3 参照）。明らかに英語圈からの教員への偏りがあるものの、地理的分布が興味深い。これ はアンケートが英語しかなかったためかもしれない。この場合、回答の少なさも結果の解釈 に重大な注意を要求する。回答者の大半は学生が 10,000 人かそれ以下の機関で働いており、 約 3 分の 1 は 11,000 50,000 人の学生を持つ機関で働いていた。回答者の半数以上は教育現 場で働いており、3 人中 2 人は公的に資金を助成された機関を代表している。（12人の）小 さなグループは私的営利目的の大学で働いていた。

回答者の大半は OER 活動に深く携わっていると話した。彼らはほとんどオープンコンテン ツのユーザであり、わずかながら製作者もいた。彼らの約半数はオープンコンテンツの利用 に際し管理者からのよいサポートを経験している。コンテンツの作成及びオープンソースソ フトウェアの使用のためのサポートはいくぶん少ない。4 人中約 1 人はオープンソースソフ トウェアの作成において管理者からよいサポートを受けていると感じていた。回答者の大半 は資料の作成及びやりとりに関して地域や国、国際レベルで何らかの提携に関与していると 話した。全体的に見て回答者からの回答に OECD の加盟国、非加盟国の違いはないか、あっ たとしてもごく小さなものであった。

カリフォルニアにおける広範囲な利用研究とデジタル資料のユーザの一部として 13 の OER プロバイダにインタビューを行った(Harley 2006)。全てのサイトは明白な意思（学生に補助 教材を提供するため、授業で講師を支援するため、全てのタイプの学習を支援する目的で一 般講座の教材を提供するため) を持って教育目的で作られている。これらは全て主に学生、

一般人及び中等教育後の教員を対象としている。インタビューを受けたプロバイダの多くは 資料が幅広い利用者に届くことを目的にしていると主張したが、これらの幅広い配信を目的 としたサイトでさえも教材がしばしば教職員にとって新たな講座を準備するのに大変役に立 つということを認識していた。よい使用データは稀だが、事例証拠は実際の利用者が対象と しているものと大きく異なることは稀であるということを示唆した。 
表 3. 1 OECD 調查に 1 機関回答した諸国（Source:OECD）

\begin{tabular}{|l|l|l|l|}
\hline \multicolumn{2}{|l|}{ Countries with one entry to the OECD questionnaire } & \\
\hline Argentina* & Finland & Mauritius* & Sudan* \\
\hline Belarus* & Ghana* & New Zealand & Togo* \\
\hline Colombia* & Iceland & Nigeria* & Trinidad and Tobago* \\
\hline Czech Republic & Iran* & Pakistan* & Turkey \\
\hline Dominican Republic* & Italy & Philippines* & United Arab Emirates \\
\hline Egypt* & Kyrgyzstan* & Romania* & \\
\hline Estonia* & Malaysia* $^{*}$ & Slovakia & \\
\hline
\end{tabular}

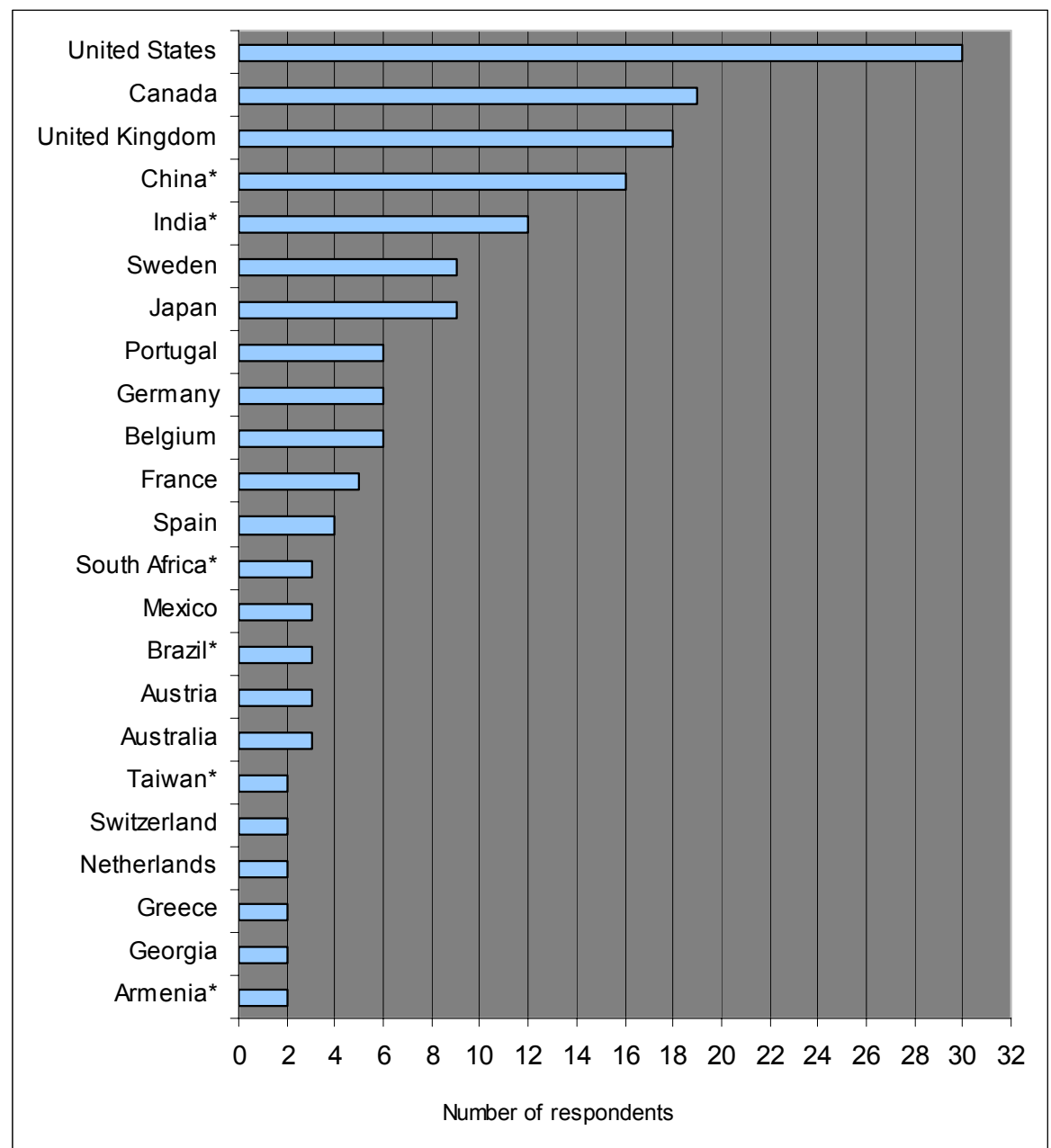

* = Non-OECD countries

図 $3.30 E C D$ 調査に 2 以上の機関が回答した諸国（Source:OECD） 
OER ユーザに関するその他の所見が、個別のプロジェクトから得られている。Carsonによ ると(2006a)、2005 年の間の MIT OCW コンテンツへのビジターが 850 万にのぼり、これは $56 \%$ 年次増加になるという。アクセス量はますますグローバル化し、57\%がアメリカ以外 からの訪問であるとみられている。21\%のビジターが西ヨーロッパからで、15\%が東アジア、 6\%が南アジアからであった。残る $15 \%$ は東ヨーロッパ、中東、アフリカ、太平洋、中央アジ ア、カリブ海の結合であった。Carson(2005)では主として学士号、修士号を持った自己学習者 がアクセス量の大半 $(47 \%)$ を占め、続いて学生(32\%)、教育者 $(16 \%)$ となっているようだと報告 している。教育者の大半は東アジア、ラテンアメリカ、東ヨーロッパ、中東、北アフリカの ような発展途上地域でサイトを利用している。自己学習者の割合は北アメリカ、東アジア、 西ヨーロッパで最多である状態が続いている。

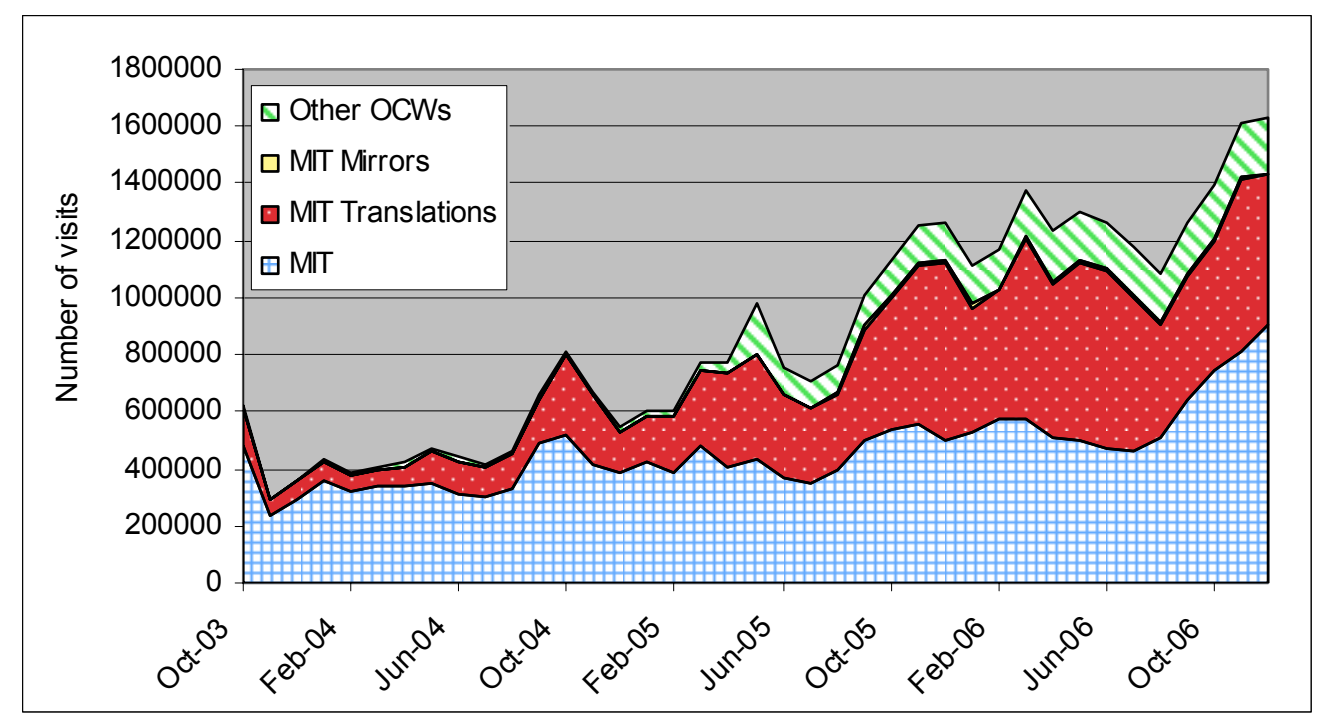

図 3.4 MIT OCW 教材へのアクセス数（2003 年 10 月〜2006 年 12 月:Source MIT）

Tufts OCW では 2005 年 6 月から 2007 年 1 月までのビジターは北アメリカからが 59\%、北

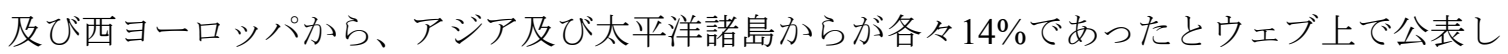
ている。彼らのユーザ調査によると、43\%が教職員メンバーあるいは学生である一方で、回 答者の半数は自身を自己学習者であると認めた。ユーザの $25 \%$ 博士号あるいはそれに相当 する学位を持っており、30\%以上が修士号あるいはそれに相当する学位を持っており、26\% が学士号あるいはそれに相当する学位を持っていた(Phelps, 2006b)。総合すると、ユーザの半 数以上が修士号かそれ以上の学位を持っていることになる(Tufts, 2006)。

John Hopkins University’s Bloomberg School of Public Health では 2005 年に OCW の試みを 始め、最初の 1 年間でビジター数が 111\%増加したと報告している。ビジターの 19\%は医療 従事者であると身分を示し、23\%は自己学習者、7\%は教育者であると示した。計 $13 \%$ 学生 であると報告し、そのうち 3\%が Hopkins の学生であった。ビジターの 64\%がアメリカから であった(Phelps, 2006a)。 
2007 年 1 月、Connexions は 100 万人を超えるアクセスが 194 ケ国からあったと報告した。 (http://cnx.org) 2006 年 1 月のユニーク・ビジター数は 2005 年 1 月の 26 万 4 千人に対して 50 万人であった (http://cnx.org/news/2006-02-07)。

異なる言語による資料の増加はサイトのビジター数を増や寸結果につながると見られる。 また、ビジターがどこから来るかということにも影響を与える。MIT OCW の翻訳提携サイ 卜は昨年の間に最も劇的にアクセス量が増加したことを報告している。2005 年のうちにそれ らの 4 つの翻訳サイトは 340 万のビジター数を記録した。ParisTech OCW では資料のほとん どをフランス語で提供しており、毎月 3 万〜 3 万 5 千のユニーク・ビジターがいると報告し ている。これらのうち、3 分の 2 がヨーロッパ（主にフランス）からであり、約 $10 \%$ がアフ リカから、そして 5〜6\%が北アメリカからである。日本オープンコースウェアコンソーシア ム $(\mathrm{JOCW})$ のケーススタディにおいては、各メンバー大学において毎月平均して 8,000〜 12,000 のビジターがありその数は増え続けていると報告されている。(Kobayashi and Kawafuchi, 2006)。

OECD アンケートの回答者の約 3 分の 2 が大なり 小なりオープンコンテンツの作成に関わ つていると話した。他の同僚を必要とするための 9 つ考えうる障壁の重要度を評価しても らったところ、最も大きな障壁は時間が足りないということであり、続いてオープンコンテ ンツ作成のための時間と労力を捧げるためにスタッフメンバーを助長する報酬制度が不足し ているということ、そして技術不足という結果になった（図 3.5 参照）。教育改革に対する 興味の認識欠如も否定的な影響を持つ重要な要因としてあった。その上この問題において教 育改革は個人の理由に共通する突出でも OER プロジェクトへ参加するための機関でもない ということに気付くことができる（第 4 章参照.)。最も重要でない障壁はコンピュータや他 のハードウェアへのアクセスの不足、ソフトウェアの不足であった。

作成した資料にどのようなライセンスを用いているか尋ねると、回答者の半数以上が何の ライセンスも使っていないと回答した。4 分の 1 はある種のクリエイティブ・コモンズ・ラ イセンスを使用しており、その他はオープンライセンスであった。クリエイティブ・コモン ズ・ライセンスの使用は増加しているが、この所見は著作権やオープンライセンスに関する 更なる意識向上の必要性を示している。これは OECD 研究の一環として行われた一連のサイ 卜訪問の間にいくつかの所見によって強化された結論である。

さらに、調査結果によると講師は OER を他の学習資料を補足する質の高いものだと考えて いることがわかる。これらの資料を使うための他の目的はたとえそれが第 3 者のコンテンツ を含んでいたとしても教材を公に利用可能にすることである。それゆえ教材をより柔軟にし、 公開性を促進しなければならない（図 3.6 参照）。 
回答者の 3 分の 2 が授業中一部または限られた範囲でオープンコンテンツを使用している と述べた。また、より小さなチャンクの学習教材の方が大きなものよりも使われているよう である。10人中約 8 人が授業において全講座よりもむしろラーニングオブジェクトや講座の 一部を使っていると述べた。回答者の半数以上が自ら作成したコンテンツを使っていると述 べた。10 人中 4 人が彼ら自身の機関の中で作られたコンテンツを使用しており、10 人中 3 人が他の機関との協力で作られた資料を使用しており、約 4 分の 1 が出版社で作られたコン テンツを使用していた。

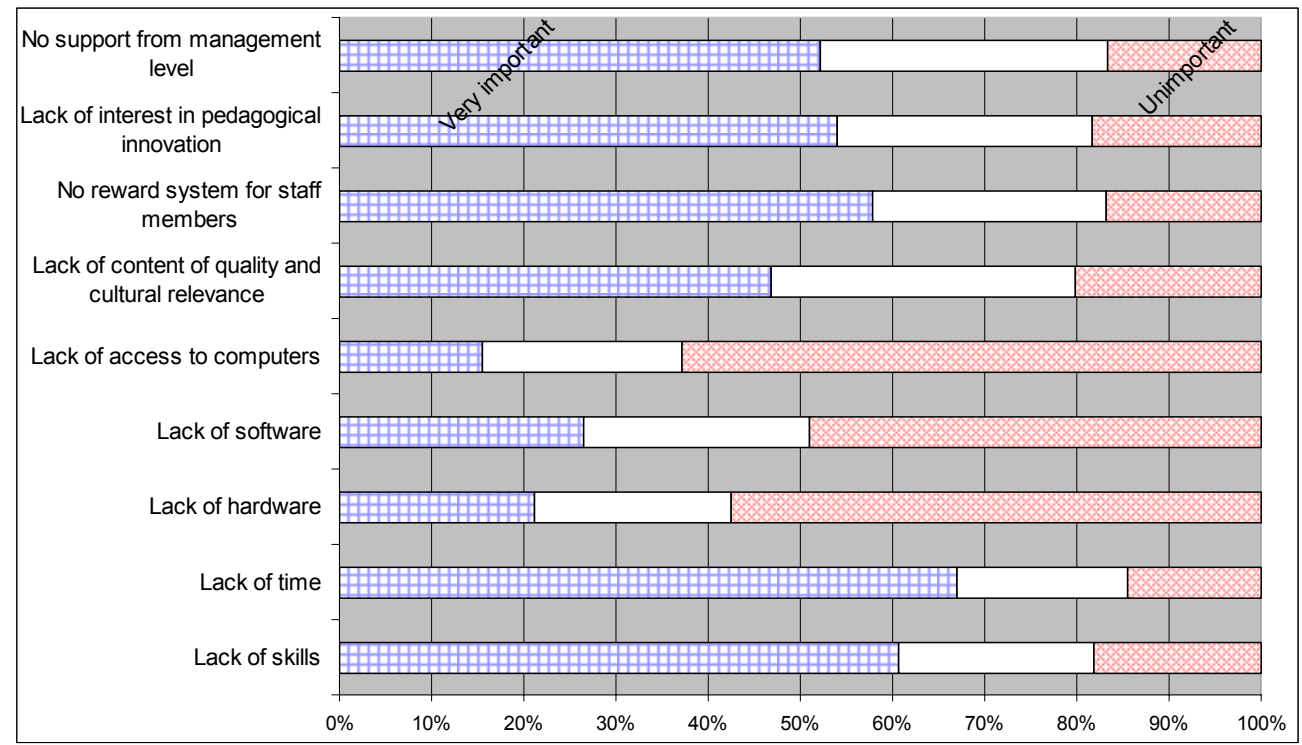

図 3.5 OER 活用の障壁 (Source OECD)

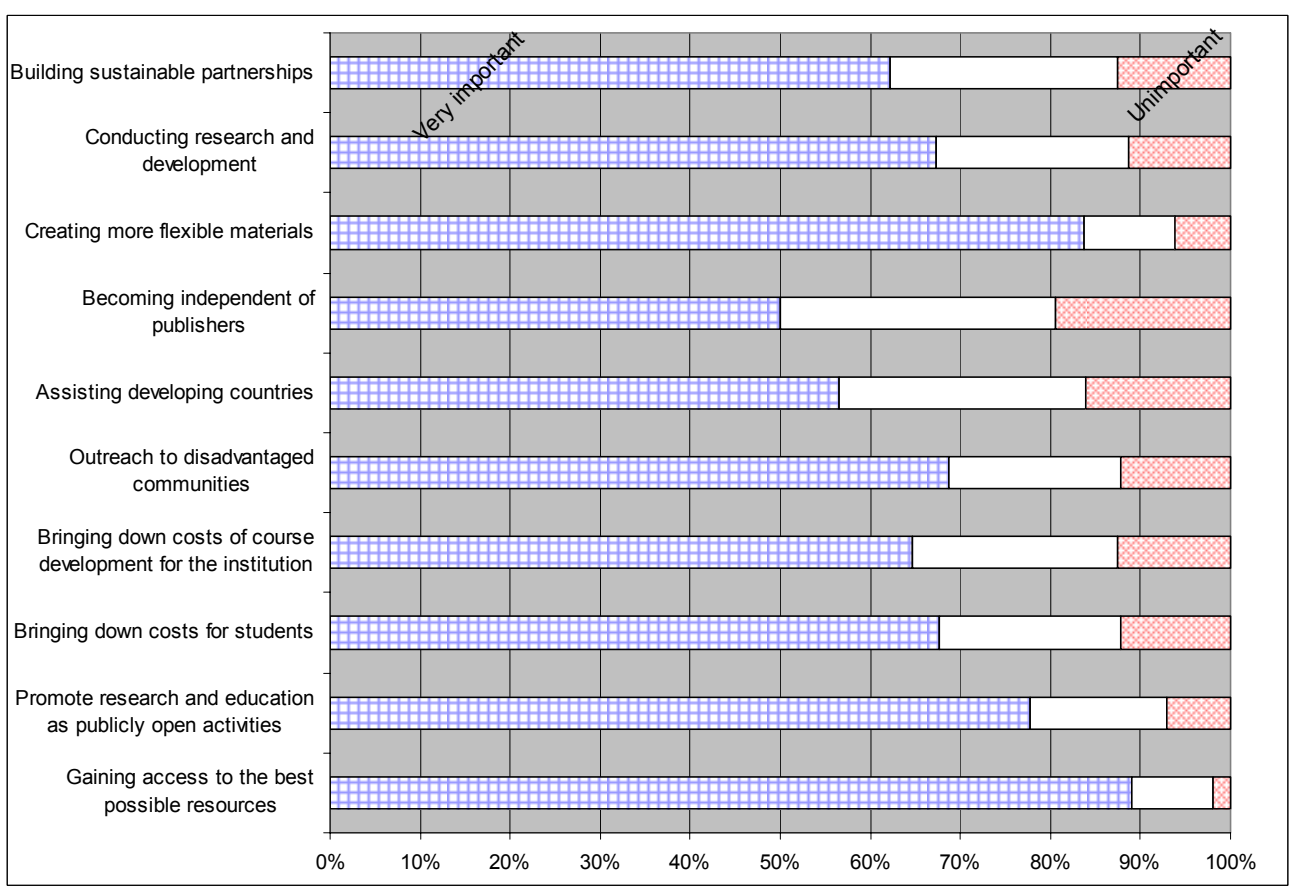

図 3.6 OER を活用する目的 (Source OECD) 
回答者に対しなぜオープンコンテンツ作成にもつと多くの同僚を関与させないのか考えて もらった。図 3.7 は最も大きな障壁は “時間の不足”であり、続いて “オープンコンテンツ 作成のための時間と労力を捧げるための報酬制度が不足しているということ”、“技術不足” であることを示している。OECD 外部では技術不足が最も重要で、OECD 内部では時間不足 が最も重要と知覚されてはいるが、同様の要因が OECD、非 OECD の両方の国の教員の間で 最も重要であると位置付けられている。オープンコンテンツの試みのための原価回収モデル の欠乏も否定的な影響を持つ重要な要素として知覚されている。非 OECD 加盟国ではハード ウェア、ソフトウェアの不足及びコンピュータアクセスの不足を問題と考えている比率が高 いものの、最も重要でない障壁は OECD、非 OECD どちらの国でもコンピュータや他のハー ドウェアへのアクセスの不足及びソフトウェアの不足であると回答者は述べている。

オーストラリアの Macquarie E-Learning Centre for Excellence(MELCOE)は、OCW ツールと e-Learning のオープン標準の開発を専門とする異なった種類の OER プロデューサーである。 いろいろある中で、現在利用者が増えている学習活動運営システム（Laerning Activitiy Management System - LAMS）を開発している（Box 3.3 参照）。

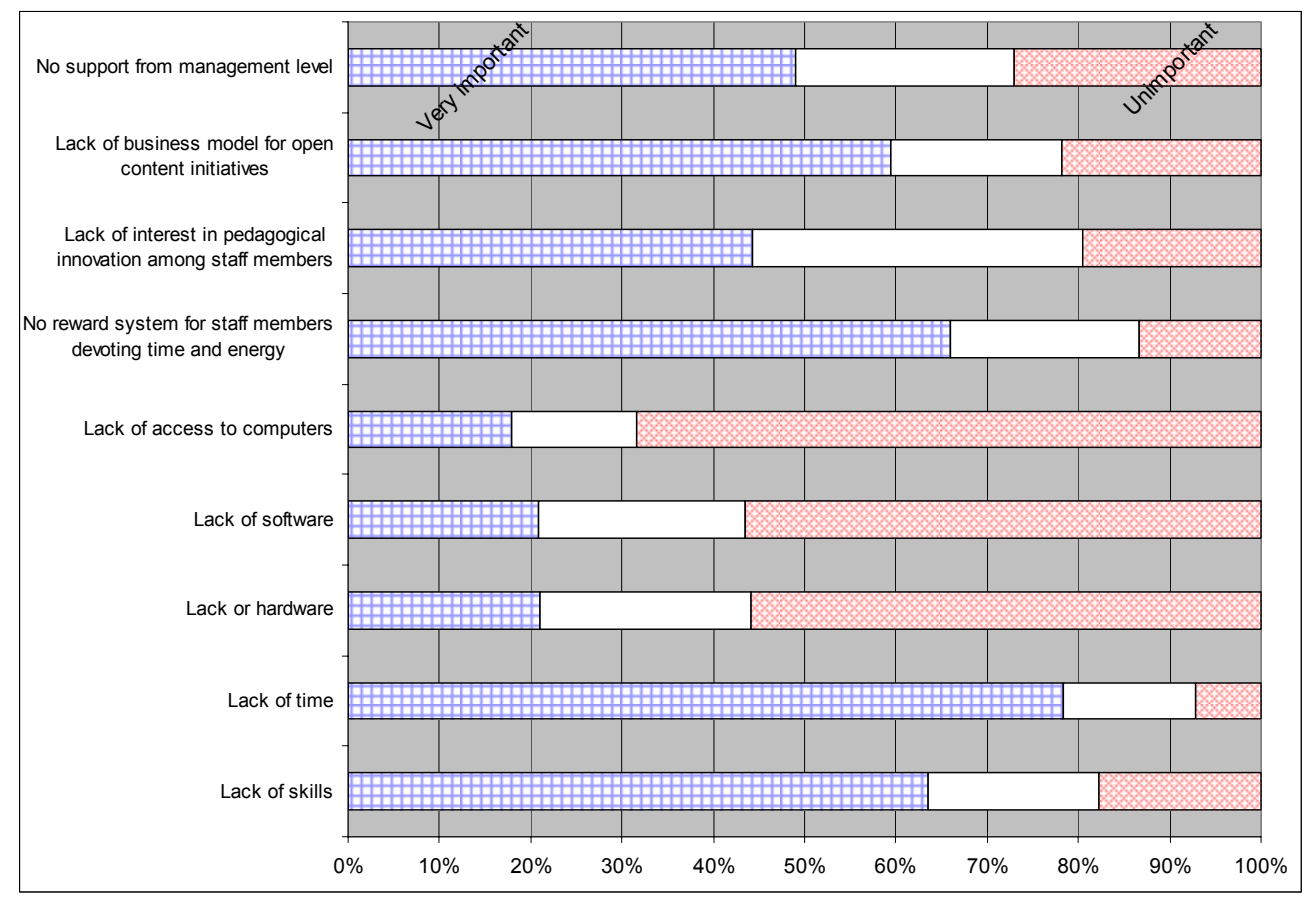

図 3.7 OER 作成の障壁 (OECD) 
MELCOE は具体的に e-Learning の研究開発のために設立された研究センターである。 MELCOE は助成 の大部分を Australian Federal Government から受け正式に大学レベルで設立された。MELCOEの研究に は多くの他大学や興味を持った商業パートナーが関与している一方で、研究開発は主に Macquarie University に向いている。MELCOE 内のオープンソースソフトウェアの 2 大製作分野は LAMS(Learning Activity Management System)と MAMS(Meta Access Management System)プロジェクトである。

LAMS は教育者が一連の学習活動を作り、使用するのを補助するためのシステムを提供する。このシー ケンスは教育上の仕事のワークフローとして考えられる。これは学生が教育上のシーケンスを通して向 上するための仕組みも提供し、協力的なオンラインの学習と議論に携わる。独自の学習状況のため、あ るいは外部の学習者がクラスベースの課題[exercises]に参加するために活動シーケンスはチュートリア ルを補足するように作られる。LAMS は教育者が広範囲で柔軟な学習活動を作り補完するために使いや すいよう設計されている。それは活動シーケンスを作るための直感的なビジュアルツールを提供するオ ープンソースソフトウェアであり、学生がシーケンスを通して向上するためのインフラであり、学生の 参加を導き評価するための管理インタフェースである。フリーソフトウェアとしての LAMS のリリー スは大学レベルで始められた。公益のため LAMS がフリーソフトウェアでリリースされるという高度 な決断が下されたのである。LAMS によってオンライン学習の進行と開発が変化することが望まれてお り、フリーソフトウェアとしてリリースされることが教育の領域に理解を増すことを意図して計画され た。

LAMS は GNU General Public License(GPL)の下で認可されている。非 GPL ライセンスでは改良版を再配 布する責任なしで LAMS を組み込むことを望む機関のためには交渉が行われる可能性がある（例えば、 LAMS をバンドルし配布することを望むクローズソースの学習管理システム[closed source Learning Management System]）。しかし今までLAMS の「二重ライセンス[dual-licensing]」は起きていない。現在 の LAMS のユーザは皆 GPL ランセンスの下でソフトウェアを手にしている。GPL は最も一般的なライ センスであるという理由で選ばれ。これはコミュニティサポート及び開発を奨励するために重要である と見られる。コピーレフトである GPL は二重ライセンス商用化の可能性が与えられるために特に他の OSI 認可のライセンスより多く選ばれていた。

Meta-Access Management System(MAMS)プロジェクトはオーストラリアの高等教育研究基盤の効率と有 効性を高めるためのミドルウェアコンポーネントの提供を目指している。MAMS は「Backing Australia’ s ability」の Systemic Infrastructure Initiative の下で Australian Federal Government による助成を得ている。 MAMS は学術情報や論文、大規模なデータセットやグリッドコンピューティング設備といった情報と サービスへのアクセスを高めるためのミドルウェアの必要性に対処している。 MAMS プロジェクトは 基礎デジタル権利管理や調査復旧、メタデータ管理のための付加的な技術サービスをまとめた、機関を またがる認証と承諾のためのインフラを提供するために設計されている。

MAMS は高等教育研究機関の間の情報共有を増加させるための中核基盤を提供する。MAMS ソフトウ ェアはApache ライセンスの下でリリースされている。Apache ライセンスは「Shibboleth」（それ自身が Apache ウェブサーバーではない) と呼ばれる Apache ライセンスによるソフトウェア上で MAMS が動 くために使われている。MAMS ソフトウェアはおよそ50 のパートナー機関の間で直接共有されている。 Source: Suzor (2006a) 


\section{2 まとめ}

まとめると、OER のユーザは誰であるか、現時点でこれらのリソースの利用方法はどのよ うなものが最も一般的かという点についてより多くの情報が非常に必要とされている。利用 できる散在しているデータを用いて、OER のユーザ及び製作者の全容を描き出すほかないの である。資料の制作者や OER プロジェクトの大多数は先進国世界の英語圈にいると考えられ る。これまで関与した機関は無名のまたは地位の低い機関に比べ、国際的に、あるいは彼ら の国々において評判がよいようである。キャンパスベース、遠隔講義の組織も同様、機関も 大小に関わらず関与している。機関の約半数は他とリソースを共有する何らかの確立した連 携に関与している。

学生や一般人もしばしば利用者に挙げられるが、それらの多くは高等教育(post-secondary) の機関にいる教育者を主要対象グループにしている。OER のユーザは世界中から訪れるよう である。多くは十分な教育を受けた自己学習者のようであるが教育者もおそらく際立ったユ ーザである。

大抵のリポジトリ又はサイトではユーザのためのログイン手続きはとっていない。また、 ウェブの統計量やその他の利用可能なデータはさまざまであり、異なる評価方法やリソース のプロバイダ及びリソースの種類による相違の結果としてこれらを比較することは困難であ り、時には不可能である。結果として生じる情報の不足はより組織的なウェブの統計量とユ ーザ調査の収集及び分析によって打開することができるだろう。もっとも、そのような活動 はとりわけ小規模で有志により運営されるプロジェクトにとっては費用と時間がかかる可能 性があるけれど、OER の動きにおいて更なる知識基盤を構築するためには、助成を行った当 事者たちが評価活動の資金調達を要求するために公開されるべきである。OCW コンソーシ アムにより、全てのコンソーシアムメンバーのための共通の評価の枠組みを構築する試みが 進められている。この講座の意思は講座を配信するだけのもの、常に機関ベースであるもの などといったオープンコースウェアプロジェクトに有効な特有の環境を築いている。このよ うのものはその他の OER プロジェクトへ完全に適用できるわけではないかもしれない。しか し、確実に他のものを築くためのよい基盤を構築しているだろう。 


\section{第四章}

\section{何故共有するのか}

\section{- オープンシェアリングの動機、利点、障害 -}

本章では、OERの利用者と制作者の位置付けをしている。はっきりした統計はないが、OER ムーブメントは、プロジェクトの数、関与する人間と利用できるリソースの数において拡が りをみせている。OER は、ほとんどのリソースはいまのところ先進諸国で製作されているが、 グローバルな展開をしている。OER ムーブメントは、トップダウンとボトムアップの両方で 成長しており、あらたなプロジェクトが機関レベルで発足し、また個々の教員と研究者は率 先して OER を利用し製作している。あらゆる種類の機関が、そして全ての領域の研究者と教 員が関与している。 
ソフトウェアやコンテンツを共有する上で、最も初歩的、かつ基本的な疑問は、「なぜ」 共有するのかということである。なぜ、無料で提供する、ということが必要なのか。何か得 することがあるのだろうか。オープンソースソフトウェア(OSS)、オープンアクセス、オープ

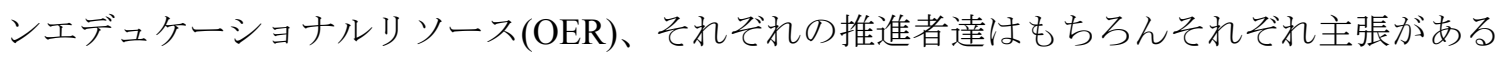
が、三つ寸べてに当てはまる、もつと一般的な論点がある。その論点は、ソフトウェアや科 学論文、教材などを共有することで得られる利点を示した「Pull 型」論と、ソフト開発者や 科学者、教育者などが情報を公開しないことで起こり得る損害やマイナス要素を示した「Push 型」論とに分けられる。

まず「Push 型」論であるが、時折議論にあがるのは、大学が調査報告書や教材の提供をし ないと、守るべき学術的価值のあるものが、マーケットの圧力によってどんどん排斥されて しまうという点である。皆が皆マイクロソフトのプログラムを使うことによるソフトウェア 市場の独占や、大多数の人がアップル社のMP 3 プレイヤーIPOD で ITUNES を聞くことに よるハードウェア・ソフトウェアの合同市場の独占が起こり得る危険性は、オープンソースソ フトウェア(OSS)を支持する理由としてしばしば挙げられる。大規模な、営利目的による科学 出版モデルの反対派によると、同じことが科学論文の独占所有や統制に関しても危惧される。 将来的に、研究結果の発表を協議する場において、研究者の立場が危うくなってしまうかも しれない。その他、コストや脆弱性が高まることや、社会的不平等が促進されること、技術 開発や科学の進歩が遅れることなどが懸念される。

次に「Pull 型」論として、オープンシェアリングによって得られる様々なプラス効果が提 示されている一情報がより広範囲に、速く普及すること、そして多くの人々が問題解決に努 められること、それがクオリティの迅速な向上や、技術や科学の発展を導くこと。また、発 展が広範囲に分散していることで、質・安定性・安全性が高まることや、ソフトウェア、科 学研究結果や教材の共有によって社会的な発展が促進されると共に、社会の不平等が緩和さ れることが提示されている。より個別的な視点においては、オープンシェアリングによって 知名度や評判が上がり、仲間と情報を共有する喜びを得られるという主張がある。

\section{1 促進要因と障害要因}

OER プロジェクトに取り組む動機が何かを見る前に、現存するその促進要因や障害要因に ついて考察しておこう。これらは、技術、財政、社会、政策、法律など様々な分野に関わっ ている。(2006 年 OLCOS、2006 年 OECD Sacha) 技術分野における促進要因には以下の項目 が挙げられる。

・有用性の高いブロードバンド

・ 大容量のハードドライブと高速・低価格のプロセススピード

・コンテンツを作成・配布・共有する技術の確立

・製作・編集・リミックスが簡単にできるソフトウェアの供給

• コストの削減と利用者向けの音響、写真、映像技術の質向上 
財政分野における促進要因も上記項目を含むが、それに加えて、コンテンツを無料で共有 できるという金銭面での利点と、無料コンテンツから、組織及び個人が新たなビジネスモデ ルを生み出すことができるという点が挙げられる。さらに教育機関においては共同運営とシ ステムの共有によるコスト削減も財政上の促進要因として挙げられる。その他の財政分野に おける促進要因には以下のようなものがある。

・ブロードバンドインターネット接続のコスト削減

・コンテンツの作成・編集・運営ツールの利用拡大とコスト削減、エントリー バリアの引き下げ

社会的側面における促進要因もまた、上記項目でカバーされる。特に、利他的な理由や個 人が得る金銭以外の利益、そして公共機関が新たな社会組織に働きかけるチャンスが得られ ることが挙げられる。他の社会的要因には、ブロードバンドの利用増加、相互運用への希望、 それにインターネット利用者、特に 12-17 歳の若年層のメディアを使う習慣を変化させてい るオンライン・コミュニティに積極的に貢献したり、それを創ったり、共有すること、など がある。法律上の要因には、クリエイティブ・コモンズやG N Uフリー・ドキュメンテイショ ン・ライセンスのようなライセンススキームなどのツールやコンテンツを作成・供給すること に伴う新たな法的手段の確立がある。また、政策上の要因としては公共の教育機関における 資料の共有・再利用を促進して納税者の権利を確立する必要性や、現状ではアクセス手段を 持つことができない個人や組織への情報提供などが挙げられる。

OER を開発・利用する上で生じる障壁に関しても、技術、財政、社会、政策、法律の分野 に応じて同じように考察することができる。技術面での障壁としてはブロードバンド環境の 不備などが挙げられる。OER の開発・共有に必要なハードウェア及びソフトウェアに投資す る資源の不足は財政的な障壁になる。財政上の障壁には他にも、教材開発や OER を長期継 続させるために必要なコストを賄うのが困難であることが挙げられる。技術面と財政面にお ける障壁は発展途上国にとって深刻な障害であるケースが多い。社会的なバリアとして挙げ られるのは、促進要因として挙げられた技術的発明を活用するスキルの欠如、異なる文化圈 の教員や組織によって作成された資料の共有・利用に伴う障害であり、OECD のケーススタ ディでもいくつかの例が提示されている。研究結果を公開し科学データを更新していくこと の重要性を強調する学術団体が、同時に、他者が作成した教材を共有し利用することに難色 を示すというパラドックスが生じている。

カナダで実施された二つのケーススタディによると、他の公共機関による誤使用の危険性 や倫理に反する競合などがその要因として挙げられている。カナダの Athabasca University の学長は以下のように明言している。

もし、公立の大学だけがアクセスできるという保証があるなら、何の問題もなくコ ンテンツを公開するだろう。公立の大学はコンテンツを道徳的に利用し、その情報 源もきちんと示すという信用があるのだ。現段階では、企業がコンテンツを営利目 的で略奪したり非道徳的に利用したり利益を追及したりすることを食い止める手 
段がないため、Athabasca University 大学はコンテンツをこれ以上公開することに難 色を示しているのである。(Stewart, 2006)

似たような問題が他の訪問機関からも示されていた(Pedro, 2006a)。社会的なバリアを考え てみると、最も重要なものは、OERの開発に時間やエネルギーを費や寸教員や研究者への報 酬制度がないことかもしれない。OER の利点を知らないことや OER ツールやコンテンツを 利用・開発するスキルの不足、そして時間の不足も障壁として挙げられる(第3 章参照)。また、 再利用する上での障壁として考えられるのは、学習リソースは文脈の上でなりたっており、 前後のリソースを統合しなければ意味をなさないという点である。リソースの統合は、著作 権が別のところにある場合、禁止されている可能性があり、そうでなくても時間やコストが かかり、困難である。法律的な障壁には作成者の承諾を得ていない著作物の使用禁止がある。

OECD のケーススタディにおいても、著作物の利用・移動の許可を得るのにかかる時間と手 間はそれら著作物を OER として公開する上で大きな弊害であるとされた。これらの障害のほ とんどは OER や I P を推進する機関における明確なポリシーの欠落からきている。以下の章 ではこれら障害要因のうちのいくつかを、より深く考察していく。

\section{2 政府が OERに関与する議論}

他の多くの諸国同様、EUの 25 力国は、知識ベースの経済と社会への移行を成功させなけ ればならいという問題に直面している。その達成のために EU はいわゆるリスボン戦略 （Lisbon Strategy）を打ち立てた。その重要な部分は、よりよい教育とスキルによるヒューマ ン・キャピタルへの投資を増やすことにある。とりわけこれは、高等教育、特に生涯学習一 の就学を画期的に増やすことを目指している。欧州委員会のJose Manuel Barroso 会長は、「リ スボンの目的達成に生涯教育は“必須条件”である」と述べている (European Commission,2005)。 リスボン戦略を出発点として、Kirschner（Kirschner, et al., 2006）等は、どのように相互に関 連する三件の OER プロジェクト（Open University in UK の OpenLearn、Open University in the Netherlands の OpenER 及び MORIL）がその目標に着手しているかについて記述している。こ れらの参加大学は、公開及び遠隔教育機関なので、時間とニーズや経験について競合する要 求を持つ独自の学習者向けにデザインされた学習リソースを作る長年の伝統を有している。 これらのプロジェクトの大事な役割は、学習が Social vacuum で行われるのではないので、学 習環境を整え、学習支援、ツールを提供することにある。European Assouation of Distance Teaching Universities（EADTU）が立ち上げた MORIL プロジェクトは、入学及び非入学プロ グラムを提供しているが、学習者たちが高等教育に順応しフォーマルな高等教育への入り口 へ入る動機付けと自信を付ける手助けをしている。学習者たちが通常の仕事に就きながら都 合の良い時間と自分のペースで学べるため、このアプローチは学習者個人と政府双方に費用 効率が高いと思われる。成功すれば、これらのプロジェクトは高等教育機会を広げる興味梁 い費用効率が高いなものとなろう。つまり、これらの例は、いかに OER プロジェクトが政 府によって高等教育機会を拡大し、ノンフォーマル、インフォーマル、フォーマル学習のギ ヤップを埋め、生涯学習推進に利用できるかを示している。 
いまのところ政府の直接の支援を得ている OER プロジェクトはほとんどない。英国は、お そらく最も野心的な例であろう。英国政府は、JISC(Joint Information Systems Committee)に教 材開発だけでなく、リポジトリを構築しデジタルコンテンツのインフラ整備のファンドを提 供している。もう一つの例は、オランダの教育、文化、科学省からそのファンドの 3 分の 1 を受けている OpenER である。さらに事例としては、インドの高等教育の急速な拡大を確認 した Indian Knowledge Commission がある（Kumar,2006）。21 世紀のチャレンジを果たすため にインドは、質の高い教育へのアクセスを広げる必要がある。その戦略の重要な部分は、多 様な地域社会の知識へのニーズを満たす OER と広帯域ネットワークを利用し、学生と教員間 のコミュニケーションを拡大し、革新的でインタラクティブな教育体験を導入することであ る。コミッションは、さらにインドが OCW コンソーシアムのメンバーになり、利用できる OER をプールすることを提唱している。Stacy（2006）は、カナダのブリティッシュコロンビ ア州が BCcampus の一環として立ち上げた 26 の中高等教育機関の機関内連携である OER プ ロジェクトについて紹介している。同プロジェクトは、政治的にも財政的にも政府の直接支 援を受けている。スペインの Extramadura は政府が支援する第三の事例を挙げている (Box 4.1 参照)。

\section{3 組織が関与する理由}

組織の側から見ると、OER に取り組むことには様々な理由があるようだ。MIT の前学長、 Vest（2004）は MIT が「全ての講義用教材をインターネットで公開する」5つの理由を述べ ている。教育を推進しアクセス空口が広がること、MIT の学部間で瓦いの研究を学べ、再利 用できること、資料の良質な記録を残すことができること、卒業生とより密な関係が作られ ること、そして MIT の学生の手助けになることである。

MIT は大学組織であるため、OCW の開始が学校の主たる財政を圧迫することはないとい う。遠隔教育で同じようなことを試みるのには危険が伴うであろう。とすると、興味深いの は、なぜ Open University in UK は OpenLearn のコースを開始したのかということだ。 McAndrew (2006)はその理由を8つ示しているが、その中にはコンテンツの公開という理念が Open University の方針に合致していることや、OER の動きが進む中で Open University も遅か れ早かれその流れに参加する必要があるということが含まれている。彼はまた、テクノロジ 一やグローバル化に焦点が当てられるべき時に何もしないことに対する懸念や、学生の肉体 の存在を超えて届くことができる OpenLearn の可能性についても述べた。さらに、この試み を、世界の新技術や新しい仕組みの基盤が作られる課程を学ぶというチャンスとし、さらに は新たな地域で Open University の教材の質をデモンストレーションしたり、同じ目的や理念 を掲げた外部組織との連携にもつながると考えられている。 


\section{Box 4.1 Extremadura の事例}

スペインの Extremadura は国内でも貧しい地域で人口も少ない。しかしながら、興味深いことに、こ の地域はオープンソースソフトウェア（OSS）、オープンカルチャー、そしてオープンナレッジの利用 と発展に公的手段を確立している。ほとんどのインフラ、備品、人材育成がヨーロッパの Commission からの投資によるものだったため、政府の見解により、国際社会への借りを返す一つの方法として、 ソフトウェア開発とオープンナレッジリソース両方の成果へのアクセスを自由化したのである。計画 は 5 段階に分けられ、実行に移された。IT インフラへの公共投資から始まり、全てをカバーする広範 な IT トレーニング施設、商社や社会的公共機関とのネットワーク確立、OSS に有用なオプション、そ してオープンナレッジへの自由なアクセスの 5 段階である。

財政アナリシスをした上で 3 千万ユーロの利益を生むべく、OSS のオプションが拡大している。教育 システムから始まり、保険サービス・そして最終的に全地域の公的な業務管理に至るまで、現在、OSS は現存するコンピュータのベースとして広範に使われている。政府はこのために、Linex という独自の システムを作り、インターネットから自由にダウンロードできるようにした。次の更新バージョンで は、教育·保険·公営企業やさらには中小企業におけるニーズまでをカバーする。このオプションは、 世界的に OSS のドメインにおける最も重要な、公的取り組みとされ、未だ並ぶ例はないようである。 教育分野での全成果と、それに続く保険分野での成果にならって、地方議会は昨年夏、公共機関で使 用されているすべてのソフトウェアアプリケーションを OSS に変えるよう、政府に指示した。

Linex の成功例や、Extremadura だけでなくラテンアメリカでも政府によって進められた継続的な OSS の普及により、次世代はオープンナレッジの時代であり、知識社会を築くためには OSS が広く普及し、 オープンナレッジが定着しなくてはならないと考えられるようになった。前述の地方議会による政治 指針は、公共のサーバーに存在する全ての知識関連コンテンツに政府が自由にアクセスできるよう権 限を与えた。これにより、政府はその情報を全ての人が閲覧できるように教育資料を開放するため、 主に財政面で援助し、オープンナレッジをさらに促進しようとしている。そして現在に至るまで、義 務教育、成人教育の場において百万ユーロもする教育資料の公開が二度要求されている。公務員の育 成に関しても同様である。しかしながら、最高水準の資料を抱え、OER の最大提供元をなりうる大学 を、どのようにしたら取り組ませることが出来るかといった問題点が残されている。

Source: Pedró (2006b) 
急速に移り変わる世界において、教育機関が何もしないことの危険性については、OECD ケーススタディと専門家会議の両方でも話題になった。特に、遠隔教育を行う大学では現状 として、主たる財源が独自の学習方法に基づいて作られ販売されている教材であることが問 題になっている。場合によっては、これらの教材はデジタル化されていないこともある。も はや世の中から徐々に消えつつある、郵送という手段を使って、学費を払っている学生に届 けられるのである。OECD の専門議会のメンバーである有名な通信教育大学の副学長代理で、 他の主要な学会の学長も務めている人物がいる。その人物によると、生産と流通における最 新モデルへの移行は、再構築されたビジネスモデルとの密接な関連が求められており、その ために OER が果たす役割は極めて大きいということだ。(Pedró, 2006c)

教育機関と OER プロジェクトによる OECD のケーススタディでは、大学における国際的 な展望の育成、発展途上国との資源の分配、教育機関による社会貢献の一貫として、地域、 国内、国外のコミュニティへのサービスを確立、有能な学生やインストラクターをリクルー トするため機関のビジビリティを高めることなどが協議された。教育機関が OER に取り組む べきとする理由には以下の 6 つの論点があると思われる。

1. 第一の論点は、情報の共有は良いことだ、という利他主義的な見方である。こ れはオープンアクセスの動きに示されている通り、学問的な伝統にも沿ってい る。公開されているというのは、教育や研究において必要不可欠である。教育 者や研究者の作成した資料は、誰もが利用・再利用できるように公開されている べきである。この議論は国連委員会でも指摘されている。「誰もが教育を受け る権利を持っている。教育は無償であるべきで・・・」(Article 26).

2. 第二の論点もオープンアクセスにおける主張と似ている。教育機関が公開した 資料は、納税者が自由に利用・再利用できるようにするべきだという論である。 文献にパスワードをかけることは、他の教育機関が仲間の立場に立って物を考 えるということをせずに盗作したりでっちあげたりすることがあるということ を意味する。ある国で作られた文献が、税金を払わなくても他国で使用される 可能性があるため、納税者の国籍を区別していないこの論には、穴があるとい われるかもしれない。しかし、Ng (2006)によれば、このような「タダ乗り」は たいした問題ではない。なぜなら、海外での学習リソース利用が国内で教員が 同じリソースを利用した時の妨げにはならないからである。むしろ $\mathrm{Ng}$ による、 「タダ乗り」は良いコミュニティを築く上で必要なことだという。直接話をす ることによって新しいコミュニティメンバーを集めることができるし、最初は 「タダ乗り」目的でも、徐々にコミュニティを尊重し、自分たちの情報も公開 するようになるかもしれない。

3. 第三の論点は、オープンソースウェア(OSS)の動向から来るものである。「与え た者はよりよいものになって戻ってくる。」共有され再利用されることでコン テンツの改良にかかるコストが抑えられ、アクセス可能な資料を有効利用する ことができる。また、皆が全てを一から作り始めなければならない環境に比べ、 同じ時間内に質の向上が望める。 
4. 第四の論点は、公的関係を育むのに有効であり、新入生を呼び込むためのショ ーウインドウのような役割を果たすという点である。MIT などの大学組織は、 教材を無料公開したことでかなりの好評を得た。他の機関も同じように評価を 得ることが出来るであろう。Carson (2006) によれば、MIT の新入生の $31 \%$ 的受 験を決めた際 MIT の OCW を知っていたといっており、その中の $35 \%$ が、公開 サイトが一つの決め手になったといっている。さらに OCW の John Hopkins の報

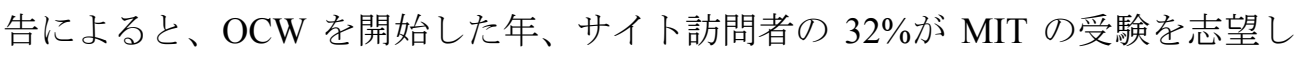
ているといっていたそうだ。今後この論がさらに深まり、より進んだ教育への アクセス手段がない人や、十分な知識をまだ身に付けていない人などにも広ま っていくことが望まれる。

5. 第五の論点は、高水準教育のグローバル化が進み、インターネットからより多 くの文献が得られるようになった結果、多くの教育機関が競い合う状態になっ たという点である。このような状況下で、コンテンツの無料提供など、新しい ビジネスモデルを作ることや、新たな財源を考えなければならなくなった。コ ンテンツを無料提供することは、教育機関の宣伝にもなるし、オープンコンテ ンツで講義を垣間見て、気に入って入学する（つまりは学費や寄付金を払って くれる）学生の空口にもなる。

6. 第六の論点は、オープンシェアリングは新たな文献の作成スピードを速め、教 育機関の進展、刷新、再利用を導くという点である。そして、資料と機関内外 における使用の記録を正確に残しておくことができる。こういった記録は、個々 の文献の市場価值を調べたい時などに市場調查の結果として使うことができる。

以上のインセンティブが更なる OER の普及を促進できるかは、現段階では判断できない。 調査をさらに進める必要がある。また、強調しておくべき点は、個々に並べられたいくつか の要素は、組み合わさって利他的な要素と財政的インセンティブを同時に進めることになる であろう。

\section{4 個人の動機}

ここまでのところ、個々の研究者や教育者、指導者が教材を共有することの利点は、オー プンアクセスやオープンソースソフトウェア (OSS)プロジェクトへの取り組みなどと比べて はっきしなく、わかりにくいであろう。個人が OER を開発することの利点もまた、多数ある。 OECD のケーススタディによる文献(Fitzgerald 2006, CED 2006, Stacey 2006) や経験を引つ張 り出してくると、次の 4 つの要素が浮上する。

1. 他者、またはコミュニティへの貢献- 共有するというのは良いことである。新 しいものが導入できるし、自分のリソースが世界中で使われているという満足 感が得られる。また、仲間と何かを共有したり、さらに発展させたりすること は喜ばしいことである。

2. 金銭ではない報酬 知名度や「エゴ・ブー」、つまり開かれたコミュニティ内で の名声である。OER の開発に取り組むことで、教材のデジタル化や版権をはっ 
きりさせて第三者がリソースを使えるようにするためのサポートが得られる。 また、講義を再構築し、体系化する良い機会となり、フィードバックも得るこ とができる。さらには、それが新たな業績につながる可能性もある。

3. 宣伝効果 - 市場に出ている出版物の宣伝になる。文献の一部やドラフトを公開 することで、最終的に出版されたものを宣伝できるのである。文献の公開によ り、情報提供者としての立場を利用して、新商品を早く市場に出せることもあ るし、新商品や新しいシステムを利用するユーザグループを確保することも可 能であろう。また、関連商品の売り上げ向上にも繋がるかもしれない。文献の 利用・再利用の記録をとれば市場調查にもなる。利用頻度の統計は広告戦略を立 てる上で必要不可欠である。また、プラットフォーム等のツールを提供すれば、 そのツールを自由に利用できるようになったユーザが共同開発者として新たに コンテンツを開発できるようになるかもしれないのである。

4. 資料をわざわざ非公開にするのは無意味である - 有用ながらも小規模な累積 的イノベーションに関しては、クリエイターが時間と労力を惜しんでパテント を取るのをやめることがある。あるいは、知的財産制度がイノベーションを確 実に保護することはできないと判断するクリエイターもいる。これは、例えば 多くの人が同じような情報を所持している場合、開発を隠しておくことは困難 であるし、簡単に模倣されてしまうからである。さらに、「自分にとってごみで も、他人にとっては金」というように、ある人にとっては無価值にしか思えな い物も、別の人にとっては 勉強になることだったり、ひらめきを生む要素にな ったりするのである。

図 4.1 に示されている OECD のアンケート結果からわかることは、教員にとっては発展途 上国への援助や恵まれない人々への働きかけ、学費の引き下げなどといった利他的な事項よ りも、実務上の問題のほうが重要視されているということだ。しかしながら、それと同時に、 最も軽視されているのは個人の金銭的報酬であるという回答結果も出ている。OER を使用し ていないと回答した教員にその理由を聞いてみたところ、OER を使用する上での主たる弊害 として挙げられたのが、時間・スキルがないこと、そして報酬制度がないことであった。教 員が OER を作るノウハウを持ち合わせていないことは、OECD のケーススタディでもしばし ば話題に上がる。その他の注目すべき弊害は、資料の管理が行き届かずに誤った使い方をさ れたり、誤解を生じたりすることに対する懸念である。こういった誤解は、OECD のケース スタディでも何度か主張されているように、リソースの前後関係がはっきりしないことから 生じる。また、同僚が教育学的イノベーションに無関心であるということも OER 使用の弊害 として挙げられた。これらの弊害は、オーストラリアで行われた、教育機関の学習環境調査 の結果（ラーニング・リソース・カタログ $\{$ Koppi, 2003\} を含む）と一致する。調查結果によ ると、ラーニング・リソース・カタログは教員が自分たちでシステムの運営を担うため、教材 や文献を公開することに対する報酬の問題は、システムの実用性を保つ上で最優先課題であ るとされている。OER の開発と利用を視野に入れた、信頼性の高い報酬システムを構築する ことが、教育や学習の場において OER を広める唯一最大の手段なのかもしれない。 
OECD のアンケートでは、回答者に公開コンテンツの製作側に立ってもらい、何を重要視 するか聞いた。ここでも、9つの選択肢を提示し、重要だと思う順に並べてもらった。図 4.1 に示されている通り、最も重要視されたのは、「資料の作成者が自分であることが認識され ること」同じく「利用者が改良・編集した資料が自分の作った者だと認識されること」そし て「資料のクオリティが再検討されること」であった。逆に重要度が低いとされたのは作成 者や作成団体への金銭的報酬であった。昇進や表彰といった形の報酬も重要度が低いという 結果になった。このことから、OERの提供に取り組む人の多くは意欲的で金銭的な利益をあ まり追求していないということがいえるであろう。

教育機関における OECD のケーススタディと OCW Initiative (Japan OCW Consortium, John Hopkins, ParisTech, and Tufts)は、MIT の OCW が提供するデータをもとに、教員の OER 開発 を共同でサポートしていくことを提唱した。これが実現すれば OER 開発にとってよいニュー スであることは間違いないが、データはまだ不十分であり、もうしばらく様子を見る必要性 があるだろう。

研究の結果、この種のプロジェクトにはコミュニティのほんの一部以外は積極的に関与す べきではないとされている（Box 4.2 参照）。

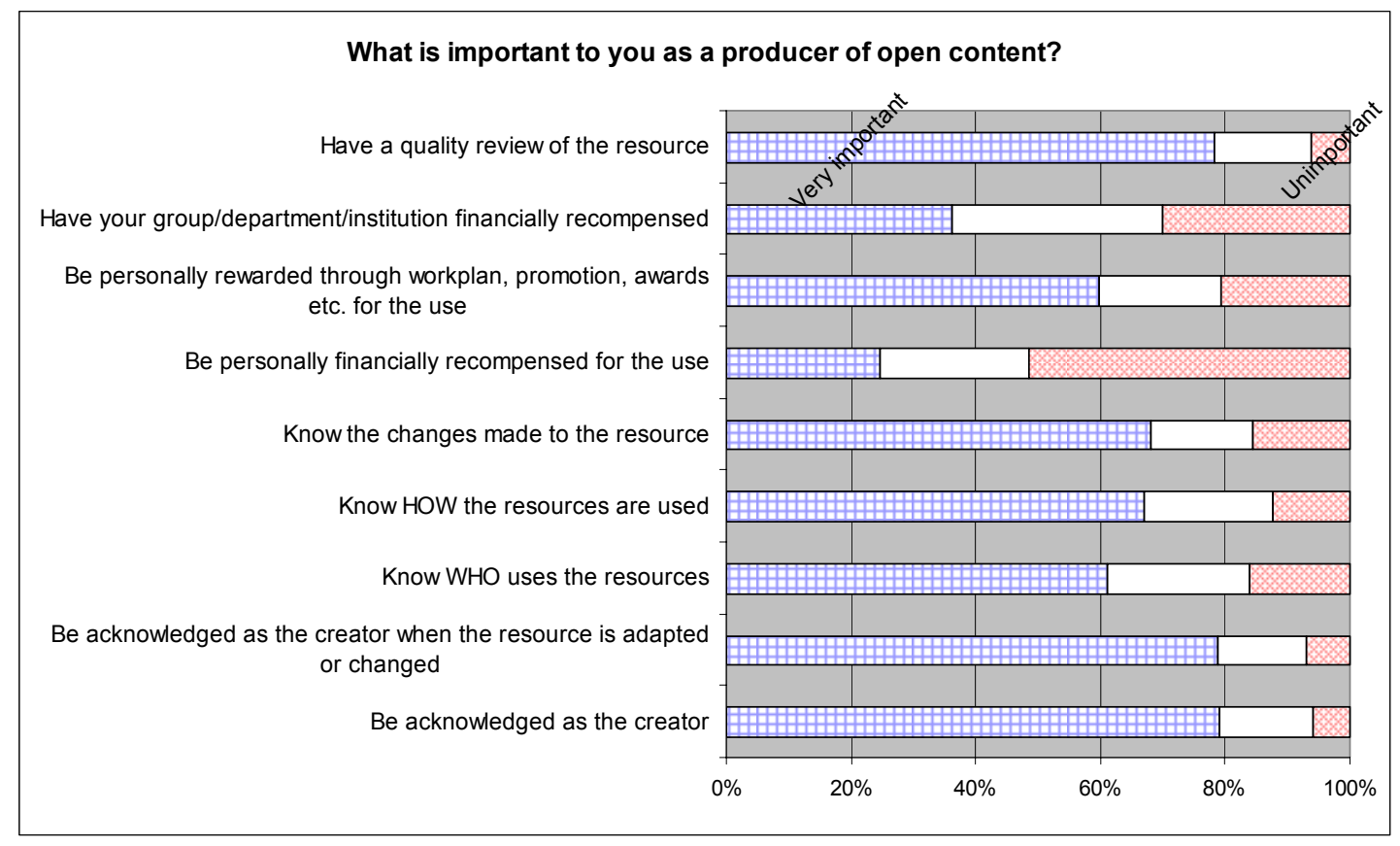

図 4.1 オープンコンテンツ作成の動機 (Source : OECD) 
Box 4.2. オープン•ラーニング・コミュニティのためのOLCOS ロードマップ どの程度の貢献が望めるか、またどうしたら参加を促進ことができるか。

学習コンテンツの管理者で、自らが管理するコンテンツを利用するコミュニティを構築したいと考える者は どれほどの貢献が得られるか問うだろう。そこである人が答える。「ざっと計算するに、100人の人間がネッ ト上にいるとすると、一人がコンテンツを作り、10人がそれにコメントしたり改良策を提示したりして関わ り、89人はただ傍観しているであろう。」(Arthur 2006）このパターンに従って、Wikipedia などの一般化 されたコミュニティコンテンツやYahooのディスカッションリストに閲覧可能データが作られる。例えば、 Yahoo Groupsではユーザ人口の 1\% がグループを作り、10\% がグループのブランチを作ったり、既にある ブランチに便乗したりして参加する。このように、「オンライン・民主主義フォーラム」（Wikiや掲示板、コ ンテンツ制作をユーザに任せているコミュニティ）の訪問者の $1 \%$ が実際のコンテンツを作る仕組みはマー ケティングコンサルタントのBen McConnell とJackie Huba (2006)によって「1\% ルール」として紹介された。

他のサイトにおいてはコンテンツを製作している傍観者がいることも考えると、作成者と利用者の比率とい うものも重要である。しかし、もっと重要なのは、「1\%ルール」ではなく、コンテンツを追加してサイ 卜に参加する 10\%を確実に確保するにはどうしたらいいかということである。OLCOS の専門家ワークショ ップで Pontydysgu (学習の架け橋)の Graham Attwell は「捜索一潜在一貢献」論とでもいうべきプロセスを提 示した。(1.) まず、トピックに関心のある人が Google などでリンクする。(2.) 次に、トピックに特化した コミュニティのH Pや Wiki の関連テーマ、トピックの専門家によるウェブログなど、より密度の濃いコン テンツを見付ける。(3.) そして、「潜伏者」となって新たな情報や議論、コメント、リンクなどを見るため に戻ってくる。(4.)もしコミュニティにニュースレターか RSS feed があればそういったサービスに申し込め る。最後に、(5.)コミュニティをよく知っていれば、彼らも貢献者になれる。従って、積極的な参加者とコ ンテントの貢献者を増やしたいと思っている教育コミュティーは戦略として、まずは関心を持ってただ見に 来るだけの学習者でも追い払ったりはしないことである。さらに、直接の情報チャンネル（通常の電子メー ルによるニュースレターや RSSfeed）と参加する機会を通して積極的にコミュニティを育てていくことが重 要である(関心ある人たちが理解を深めるのを助ける他のオプションについては、Ross の実践的な提案、2002 及び SitePoint Community,2003 を参照）。

しかし、グループメンバーのアクティブな核はどの程度大きくなれるのか? 人類学的な考察によると通常の 指標は150人くらいとされている（Dunber, 1996）。このことは、部族のサイズや会社の成長に、または特定 の研究課題についてネットワークを形成したり協力する科学者の数についての研究結果により確認されて いる。

Source: $\operatorname{OLCOS}(2007)$ 


\section{5 まとめ}

教育や科学における情報の公開・共有は以前から進められていて、その最も新しい取り組 みが、OER の開発である。競争社会において知的財産を無料で提供するという、一見パラド ックスだと思われることも、なぜ教育機関において OER プロジェクトが推進されるのかとい うことを考察していくと、実は教育の質向上を目的とした新しい展望に沿ったものであるこ とがわかる。学習コンテンツの製作・使用・配布における新しい試みがなされており、財源 の調達方法や学生の呼び込み方についても見直されている。

個々の教師や研究者に関しても同じことがいえる。彼らの多くは仲間と資料を共有したり 共同で開発したりすること自体にやりがいを感じるが、それ以外の利点も同時に存在する。 現在 OER の強みの一つとして挙げられるのが、それぞれ異なるきっかけから作られたシステ ムが共存しているということである。

いまのところ OER プロジェクトを高等教育への就学を増やしたり生涯学習推進のために 利用できると捉えている政府はほとんどない。この報告書で述べられたプロジェクトを指標 として、より多くのプロジェクトが推進されるよう望まれる。開発を促進している技術ドラ イバのリストや OER の活用に関しては第 7 章でさらに詳述するが、高等教育機関の中はもち ろん、機関の外でもユーザの作成したコンテンツによるユーザの参加を推進する動きがある のはもはや明らかであろう。今後、OER の製作と利用を奨励する機関の取り組みとして期待 されているのは、著作権の明確化やオープンライセンスの使用、そして何より OERの開発 や利用に貢献した教員や研究者への報酬システムの構築である。表 4.1 に OER の開発や共有 への促進要因、抑制要因及びモチベーションを要約している。 
表 4. 1 OER 開発と共有への促進要因・抑制要因及びモチベーション

\begin{tabular}{|c|c|c|c|}
\hline \multicolumn{4}{|c|}{ Motivations for producing and sharing open educational resources } \\
\hline Governments & \multicolumn{2}{|l|}{ Institutions } & Individuals \\
\hline $\begin{array}{l}\text { Widening participation in higher } \\
\text { education }\end{array}$ & \multicolumn{2}{|l|}{ Altruistic reasons } & $\begin{array}{l}\text { Altruistic or community supportive } \\
\text { reasons }\end{array}$ \\
\hline $\begin{array}{l}\text { Bridge the gap between non-formal, } \\
\text { informal and formal learning }\end{array}$ & \multicolumn{2}{|c|}{$\begin{array}{l}\text { Leverage on taxpayers' money by } \\
\text { allowing free sharing and reuse } \\
\text { between institutions }\end{array}$} & Personal non-monetary gain \\
\hline \multirow[t]{4}{*}{ Promote lifelong learning } & \multicolumn{2}{|c|}{$\begin{array}{l}\text { "What you give, you receive back } \\
\text { improved" }\end{array}$} & Commercial reasons \\
\hline & \multicolumn{2}{|c|}{$\begin{array}{l}\text { Good public relations and showcase to } \\
\text { attract new students }\end{array}$} & $\begin{array}{l}\text { It is not worth the effort to keep the } \\
\text { resource closed }\end{array}$ \\
\hline & \multicolumn{2}{|c|}{$\begin{array}{l}\text { Growing competition - new cost } \\
\text { recovery models are needed }\end{array}$} & \\
\hline & \multicolumn{2}{|c|}{$\begin{array}{l}\text { Stimulate internal improvement, } \\
\text { innovation and reuse }\end{array}$} & \\
\hline \multicolumn{2}{|l|}{ Underlying drivers } & \multicolumn{2}{|c|}{ Underlying inhibitors } \\
\hline \multicolumn{2}{|c|}{$\begin{array}{l}\text { Technical: Increased broadband availability; increased hard } \\
\text { drive capacity and processing speed; new and improved } \\
\text { technologies to create, distribute and share content; simpler } \\
\text { software for creating, editing and remixing. }\end{array}$} & \multicolumn{2}{|c|}{$\begin{array}{l}\text { Technical: Lack of broadband and other technical } \\
\text { innovations }\end{array}$} \\
\hline \multicolumn{2}{|c|}{$\begin{array}{l}\text { Economic: Lower costs for broadband, hardware and } \\
\text { software; new economic models built around free content for } \\
\text { recovering costs. }\end{array}$} & \multicolumn{2}{|c|}{$\begin{array}{l}\text { Economic: Lack of resources to invest in broadband, } \\
\text { hardware and software. Difficulties to cover costs for } \\
\text { developing OER or sustaining an OER project in the long } \\
\text { run. }\end{array}$} \\
\hline \multicolumn{2}{|c|}{$\begin{array}{l}\text { Social: Increased use of broadband, the desire for } \\
\text { interactivity, increased skills and willingness to share, } \\
\text { contribute and create online communities. }\end{array}$} & \multicolumn{2}{|c|}{$\begin{array}{l}\text { Social: Absence of technical skills, unwillingness to share or } \\
\text { use resources produced by someone else. }\end{array}$} \\
\hline \multicolumn{2}{|c|}{$\begin{array}{l}\text { Legal: New licensing regimes facilitating sharing of free } \\
\text { content. }\end{array}$} & \multicolumn{2}{|c|}{$\begin{array}{l}\text { Legal: Prohibition to use copyrighted materials without } \\
\text { consent. }\end{array}$} \\
\hline
\end{tabular}




\section{第五章}

\section{著作権とオープンライセンス}

本章では、著作権とオープンコンテンツ及び著作権所有者の権利への限られた例外について 調べる。クリエイティブ・コモンズ・ライセンスとデジタルリソースを利用するための権利 取得の実質的な難しさ、OER の商業利用、及び著作権法に関する大学人の認識不足など、著 作権法が提起する OER の更なる利用と制作に関わる重要な障壁について論述する。 
インターネット及び関連するデジタル技術により私たちは情報と知識ネットワークへア クセスし構築できる膨大な可能性を得ている。最も基本的なインターネットユーザでさえ、 廉価に、そして良質に世界中へ情報と知識が伝達できる。要するに、近年のデジタル技術の 発展により知識管理のための膨大な新しい展望が開けたのである。

著作権は通常知的所有権として言及されるものの一部である。Wikipediaによると知的財産 とは情報やアイデアまたはその他の無形資産の特定のタイプを各々の表現形式で伴う様々な 法律上の権利のための包括的用語である。この法律上の権利の所有者は通常知的財産の対象 に関して様々な独占権を行使寸る資格が与えられる。著作権とは対象が知性や知力の成果で あるアイデアを反映している。そしてその知的所有権は他のどの形式の財産とも同様の方法 で法律によって保護される。知的財産法は重複の程度は多少あるけれど異なった対象形式を 保護する目的で作られている。

知的財産の 5 大カテゴリ :

- 著作権 - 創造的、芸術的な作品（例：書籍、映画、音楽、絵画、写真、ソ フトウェア）において存立し、著作権保有者に一定の期間の間その作品の 複製や脚色を管理する独占権を与える。

・ 特許 - 新しく、役に立ち、自明でない考案に対して与えられ、特許所有者 に一定期間（大体特許申請の出願日から 20 年）の間考案を商業利用する独 占権を与える。

・商標 - 異なる商売の製品またはサービスを区別するために使われる特有の 表示を保護する。

・意匠 - 工業物（例：予備部品、家具、織物）の概観やスタイル、デザイン を保護する。

- 企業秘密 - 商習慣あるいは商売の独自知識に関する秘密、非公的情報、公 開することが違法になる可能性のあるもの。「機密情報」と同等、あるい は一部として扱われる。

知的財産法はとりわけ異なる司法権間の法的差異を考慮する際には専門知識を必要とする 高度に特殊化した領域である。このため OECD では Brian Fitzgeraldに論文を委任した。本章 では特にこの論文を利用する。フルペーパーはプロジェクトウェブページ (www.oecd.org/edu/oer)上で見ることができる。この報告書の目的はオープン教育の動きとこ の領域への関心の高まりから生まれた最重要課題の外観を与えることであるため、本章の範 囲では著作権問題に限定する。さらに、オープンソースソフトウェアッールのためのライセ ンスからは離れ、コンテンツ問題に限定する。なぜならオープンソフトウェア(OSS)のための ライセンスは現時点で問題は少なく一般学術人口への当面の興味が少ないのである。 


\section{1 著作権とオープンコンテンツ}

著作権法は国際協定からその記述をとり、ほとんどの国で同様である。これにより、著作 権所有者の許可なく公の著作物（文学、劇、音楽、芸術作品や映画、録音）を複製、複写、 伝達、伝送できないように規定されている。要するに、現ルールでは著作権所有者により明 確に許可されていない使用は全て禁止されているのである。著作権はそもそも経済機能を満 たすものである。限られた期間（通常は創作者の死後 50〜 70 年）、創作者はその創作物にお ける独占権を与えられることによって、著作権はその創作物の使用に際し彼らが（望むべき） 報酬を受け取ることを可能にする。これは次々に更なる創造性と革新のためのモチベーショ ンを提供する。しかしながら、市場での競争を制限しないようにも注意する一方で、ほとん どの著作権法は革新と創造性の分野でモチベーションを提供することと、著作物の使用者の ために情報へのアクセスを保証することのバランスを提供するために構築されてきた。国際 レベルでは、著作権法はとりわ教育、研究、情報アクセスにおいては作者の権利やより大 きな公益のような政策目標を競うことのバランスであると長く考えられてきた(Fitzgerald et. al., 2006)。

著作権所有者の独占にはいくつかの重要な（しかし限定された）例外が存在する。許可は 法廷の、あるいは強制的ライセンス（通常、課税、著作権使用料、またはライセンス料の支 払いを前提とする）によって供給されることができ、また、例えば、ごくわずかな部分の使 用や公正使用/公正取引が行われた場合には全く必要とされない。私的利用や教育利用はたい ていの管轄では法廷の、あるいは強制的ライセンスの下での公正使用/公正取引として、また は特定の例外の結果としてある程度許可されている。しかし、これらの例外は常にその範囲 に限られ、ある特定の状況に限定されている。それゆえに、技術が私的利用や教育利用のた めの著作物の有意義な使用を促進寸るための潜在的な可能性を持っているにもかかわらず、 著作物の再利用における法的規制がしばしばデジタル環境でその全面的な利用を妨げている。

Fitzgerald ら(2006)の説明によると、この新しいデジタルでバーチャルな知識展望の成長は、 アクセスや使用を通して著作権所有者によるより強い管理が行われる可能性をも引き起こし ている。大部分がデジタル配布とライセンスモデルの第 1 世代により可能になり提供された 主要な学術論文の購読費の上昇は、知識を広めるための新たな方法を見付けることに不満を 抱いた研究コミュニティに動機を与えた。インターネットの膨大な可能性と従来の論文のラ イセンスに示される制限の増加に直面し、世界中の研究者はオープンアクセスとして知られ る動きで結束した。オープンアクセスとは、タイムリーにインターネットを通して広く自由 に知識を広めることを狙いとするものである。多くの研究が公的に資金提供されるという事 実によって拍車がかかり、オープンアクセスへの動きは世界中の注目と支持を獲得した。4 章に示したように、OER の動きはオープンアクセスの動きとこれらの要因を共有しており、 教材の作成、配布、共有の新たな方法を模索している。オープンソースソフトウェア (OSS) の動きとして同様の方針を選ぶとしても、彼らは著作権反対者にはならなかった。代わりに 彼らは異なる種類のオープンライセンスを作った。オープンライセンス作成の背後にある構 想は、人々が訴えられる心配をすることなく著作物を共有、再利用することができるインタ 一ネット世界の場、すなわち創造的共有地を目的としている。これを行うため、著作権所有 者はあらかじめ許可を与える一般ライセンスを通して、彼らの教材を共有することに賛成あ 
るいは許可を与えなければならない。クリエイティブ・コモンズ・ライセンスは今のところ 圧倒的によく知られ、コンテンツに使われているライセンスである。特にオープンソースソ フトウェアツールについては多くの同じようなライセンスがある。実際の数はある程度「オ ープン」をどう定義するかによる。

CreativeCommons は世界規模のプロジェクトである。この報告書がまとまった時点でライ センスは、35 ヶ国の法規定に合うよう翻訳されており、他に 24 ヶ国でも同様に翻訳が進ん でいる。Creative Commons は、著作権所有者がオープンコンテンツライセンスプロトコルを 通して彼らの教材のライセンス使用を促すことによって、配布された情報の共有地を作り、 その結果創造性と革新を目的としたコンテンツの識別、譲渡、再利用を推進することを目的 としている。コンテンツを最小限の取引活動で再利用可能にすることを保証することによっ て、著作権コンテンツをより「使える状態」にすることを狙っているのである。Creative Commons の重要な点として、効率的な識別や分類の仕組みの使用、そして法的枠組みの理解 や実施が容易であることがこの目的を促進するために不可欠である。これは Creative Commons ラベルの下、最小限の手間でコンテンツを加えることのできるコンテンツの公的配 布のための一般プロトコルまたはライセンス期間の制定によって行われている。要するに著 作権所有者に、再利用性を高め情報共有地を作るために設計されたプロトコル規準上で教材 を「ライセンスアウト」または配布しても構わないか尋ねるという考えである。

Creative Commons のようなオープンライセンスは著作権を摇るがそうとしているのではな い。それどころかこれらはオープンアクセスを流れに沿って構築するために著作権所有者の 権限と法律を頼りにしている。Fitzgerald and Fitzgerald (2004)の説明によると：

Free Software Foundation...の Richard Stallman とその相談役が見出した有力な見識に よると、知識のためにオープンアクセスを構築したいのであれば知的所有権を基盤 として最大限活用または利用しなければならない。天才 Stallman は、情報コミュニ ティや創造的共有地を作りたければ一度手を離れても情報を利用できる必要があ るという倫理を理解し実施していた。この流れに沿った活動の規定は、出典の知的 所有権（慣例における著作権）を要求し、ライセンス（GNU General Public License） を通してその流れに沿った使用を構築することによって得られた。これは単純な情 報の「無料での寄付」ではなくむしろ情報を自由という意味での「フリー」のまま にすることを保証するための戦略的手段であった。オープンソースコードからオー プンデジタルコンテンツへ発想を広げた Creative Commons のような試みを今では 見られるということは、この土台に基づいている。

教育ユーザがますますカットアンドペースト、リミックス、コラボレーション、即時イン ターネットアクセスの文化に関与していくであろうデジタル世界において、オープンコンテ ンツライセンスにより文化、教育、革新の名において知識の共有や再形成のための極めて重 要な便宜が提供されるだろう。著作権の基本方針を尊重する一方で、オープンコンテンツラ イセンスにより既存の体系に基づいてことを進めるという方法でより広範な情報管理の理解 が可能になる。オープンコンテンツライセンスが教育リソースの著作権管理、配布、利用に おいて重要な選択肢になるであろうことはほぼ間違いない。 
Box 5.1 内で記述したクリエイティブ・コモンズ・ライセンスの異なったバージョンは 2 章の公開性の議論につながる。「ライセンスは複写、配布、表示、デジタル実行、作品の逐 語的な他形式一の複写を行う権利を与えられる」と記載している最初の基本特性は、Creative Commons の下でライセンスされた全ての教材のためのレベル I の公開性を保証している。資 料に含まれる情報を読んだりアクセスしたりできる限り、レベル I の公開性はクリエイティ ブ・コモンズ・ライセンスの最も限定的なバージョンに適合している。一方で資料を修正し たり付加価值を付けたりするための権利を必要とするレベル III の公開性は、クリエイティ ブ・コモンズ・ライセンスにおいて非派生(NoDerivatives)条項に適合しない。第 6 章でより詳 細に説明するように、OER の商業利用の問題は懸念が高まっている。異なる公開性のレベル がコンテンツやツールの商業利用について言うことは多くないが、上のボックスでも示した ように、非商用(Non-Commercial)条項ではこのような利用を全て除外している。

Creative Commons に対する批判は、2 章で定義したようなフリーコンテンツの支持者、及 びCreative Commons を創作者の権利を劦かすものと見なしている商業団体の両方から来てい る。 ${ }^{1}$ 商業批評家によると発行者もユーザも一様に、Creative Commons やその他のライセンス のようなフリーで利用可能な作品に代金を支払う意思は少ないようで、それゆえに創造的作 品の価值が低くなっている。いくつかの選択肢、すなわち NoDerivatives と Non-Commercial 条項では Mako Hill と Möllerにより定義された「フリーコンテンツ」に適合しないが、自由 活動家はライセンスのセットが主に全体として引用されるという立場でCreative Commons に 賛成していない。特に、Stallman はこの不備のために現時点で Creative Commons を支持する 意思はないと言っている。 ${ }^{2}$ Creative Commons プロジェクトは異なる状況でどのタイプのラ イセンスの選択肢が使われているか明確にするための新しいアイコンのセットを作成した。

\footnotetext{
${ }^{1}$ See http://wiki.creativecommons.org/CcDebate\#Criticisms_of.

${ }^{2}$ See www.fsf.org/blogs/rms/entry-20050920.html and http://yro.slashdot.org.article.pl?sid=06/02/07/1733220
} 


\section{Box 5.1. The Creative Commons licenses}

クリエイティブ・コモンズ・ライセンスは、デジタルコンテンツにおける法律上の権利を協議する際に 用いられる種のライセンスの一部分である。オープンコンテンツに対するライセンスは他にも多くの種 類が存在するが、クリエイティブ・コモンズ・ライセンスは最近 3 年間で非常に注目と人気を集めてき た。クリエイティブ・コモンズ・ライセンスは、ソフトウェアのために作られたものではなく、他の創 造的な著作物(ウェブサイト、学習資料、音楽、映像、写真、ブログ等)に関する利用を意図して作られ ている。様々なオープンコンテンツのライセンスの条文と同様に、このプロジェクトは、創造物をライ センス形態に従わせるために使われるメタデータを、機械が読むことのできる方法で開発してきた。著 作権所有者は、全てのクリエイティブ・コモンズ・ライセンスに含まれる特定の”基準”権利や制限に加 え、多くのライセンスオプションを選択し、それらを単独、もしくは組み合わせて利用することができ る。

\section{基準の特徴}

次のような特徴は、全てのクリエイティブ・コモンズ・ライセンスに対して共通である。

- ライセンス受取人は、複製、配布、表示、電子的実行，同種または異種の形式に逐語的に複製 する権利が認められている。

・ ライセンスは、世界中で適用され、著作権の続く限り有効であり、廃止できない。

・ ライセンス受取人は、著作物へのアクセスを制限するために技術的な保護手段を用いてはなら ない。

・ 著作権に関する注意書きは、著作物の複製から削除されてはならない。

・ 著作物の全ての複製は、ライセンスへのリンクを保有しなければならない。

・著作物の製作者は特定されなければならない。

- 現存する著作権例外と制限の下で許可されている範囲の活動に加えて、更なる防護策を許すと いう点で「公平な使用/ 公平な取り扱い plus」である。

\section{追加の特徴}

著作権所有者は、オプションランセンス条件から選択することができる。

- 非商用(NC): 第三者は、非商用の使用に限り、複製、配布、展示、著作活動やこれらに基づく 派生活動を行うことができる。

- 非派生用(ND): 第三者は、複製、配布、展示と厳密な複製を作成することだけができ、派生物 を作成することはできない。

・ 平等(SA): 第三者は、派生物を、配布物と同様のライセンスの下で配布することができる。 これらの要素を混ぜ合わせ適応させることで、著作権所有者は以下の 6 つの主なライセンスから選択す ることができる。

・ 創作者の明示(BY):第三者が、著作物を使い何かができるという点で最も融通のきくライセン スである。商用の場合でも、最初の製作者として著作者を明示する限りは、複製、配布、再利 用とその著作物に基づいた創作活動が可能である。

- 非商用-創作者の明示(BY-NC):このライセンスは、非商用に用いる場合で、著作者をオリジナ ルの創作者として明示する限り、複製、配布、再利用と著作物に基づく創作活動が可能となる。

$($ 続<) 


\section{Box 5.1 （続き） The Creative Commons licenses}

- 平等-創作者の明示(BY-SA):このライセンスは、商用の場合でも、創作者とライセンスに変更 を加えない限り再利用と著作物に基づいた創作活動が可能である。

- 非商用-平等-創作者の明示(BY-NC-SA):このライセンスは、非商用に用いる場合で、新しい創 作物に対してもとの創作物と同じ創作者とライセンスを付与する限り、再利用と著作物に基づ いた創作活動が可能である。

- 創作者の明示-改変の禁止(BY-ND):このライセンスは、商用、非商用のどちらの場合でも、全 く改変されず、改変物を作成するために使われず、創作者をオリジナルの創作者とする限り、 著作物の現時点での形態での利用が可能である。

- 非商用-改変の禁止-創作者の明示(BY-NC-ND):このライセンスは、6 つの主要ライセンスの中 で最厳しいライセンスである。このライセンスはしばしば「広告」ライセンスと乎ばれる。 著作物には複製とオリジナルの形態で他者と共有することのみ許され、非商用の場合にのみ用 いることができ、創作者はオリジナルの創作者となるからである。このライセンスは、改変物 の作成や、著作物の商用利用を禁じている。

ライセンスは、3つの段階で提供される。

(1)「一般人が読むことのできる」Commons Deed (ライセンスの要約)。誰もが理解できる形で著 作物に対する自由を記述したもの。

（2）「法律家が読むことのできる」Legal Code一(詳細な法律的「但し書き」)一著作物に関連する 自由に対して法的強制力を持たせたもの。

(3) 機械が読むことのできるメタデータ。コンテンツに関連する自由を、コンピュータが判読でき るようにするもの。

第 1 , 第 2 の階層は他の言語に対して「移植」(翻訳、法律的に適応)される。

クリエイティブ・コモンズ・ライセンスは、2002 年の 12 月に開始された。一年後には、100万ものリ ンクがクリエイティブ・コモンズ・ライセンスに対して作成された。2004 年の 12 月には 600 万になり、 2005 年の 12 月には 4500 万、2006 年の 6 月には 145 万になった。クリエイティブ・コモンズ・ライ センスが現時点においても指数関数的に広がっていることを明らかにしている。

2006 年の 6 月には、異なるライセンスオプションを用いるものの割合は以下のようになった。

・ 創作者の明示(BY)は 96.6\%の著作者に用いられている。

- 非商用のオプション $(\mathrm{NC})$ は $67.5 \%$ に用いられている。

- 平等(SA)は 4.54\%に用いられている。

・ 改変の禁止(ND)は $24.3 \%$ に用いられている。

時がたつにつれ、人々はよりフレキシブルなライセンスを利用する傾向があるように見られる。NCオ プションの利用は、2005 年 2 月の $74 \%$ から減少しており、また ND と SA オプションにも同様の傾向 を見ることができる(2005 年 2 月には 33\%、49\%)。また、3 分の 2 のライセンス利用者が改変を許可 していることも注目すべき点である。

Source: Creative Commons, Fitzgerald (2006) 


\section{2 障壁}

\section{公平な使用と教育的な使用}

一般に、著作権で保護されたものを公に許可なく複写し、コピーし、伝えることができな いという規則に適用される 2 つ重要な例外がある。公平な使用／フェアな取り扱いと教育 的な使用である。デジタル時代の著作権で保護されたものの教育的な使用に対する障害に関 する Fisher and McGeveran(2006)の白書では、デジタル学習のためのコンテンツ利用を保護す る著作権に対する例外は、「しばしば狭いか、厄介であるか、新技術と互換性がないか、ま たは漠然としている」と結論している。

米国では、教員と学生に「授業に使われる教室または類似する場所」で使う権利を与えて いる、教室での使用例外がある。しかし、たとえオンラインアクセスが教員と学生に限られ ているとしても、この例外がクラスのウェブページ、ブログ、または Wiki の使用を考慮に入 れるかどうかは明らかではない。さらに、Fisher and McGeveran（2006）は、それを説明する：

[教室での使用]例外は、教室でコンテンツを利用する教員の公的な責務を無効に するが、他の権利（再生権利を含む）は含まれない。教員が単に直接的にアナロ グのコピーを示した時には、これは十分だった。しかしデジタル環境では、教員 がイメージを PowerPoint のスライドに挿入する時のような付帯的な転載は当り前 である。転載が公明正大な使用信条の下で保護されているという正当な論拠があ る一方、他の権利の省略は確かに教室使用例外の効果を制限する。

2001 年の The Technology, Education and Copyright Harmonization Act は、新しい技術的現実 を考慮して教育的な使用免除を更新するアメリカ議会による試みを意味する。そして、Fisher and McGeveran（2006）によれば、通信教育に対する新しい用意は、デジタル環境での教育者 に、いくらかの限られた更なる保護を与える。しかし、権利所有者によって求められるいく つかの契約は、法規にも取り入れられた。相まって、これらの制限一それがカバーするデジタ ル学習の範囲が制限されるということである主要な問題のうちの 1 つ-によって行為の範囲 をとても制限し、大部分の遵守者がそれを提供する責任からの例外がほとんど価值を持たな いと思っているその要求に応ずることを教育者にとってとても難しくする。

他の国の状況を調べた白書もある。ヨーロッパの国がむしろ異なる方法で EU 著作権管理 条項を実行する一方、インドと中国では、法律はオンライン学習にとって有利になっている ようである。各国は 4 つの集合に分けられる。数力国（ベルギー、ドイツ、ギリシャ、ハン ガリーとリトアニア）は、利用可能な記事と本の短い抜粋の再利用と製作を許可する。数力 国（ルクセンブルク、ポルトガル、スロバキア）は、短い抜粋だけを許す。数カ国（エスト ニア、スロベニア）は対面講義を例外とする米国と同じ用意があるが、実質的に他のいかな る違反しない教育的な使用も認めない。そして最後の一国（マルタ）は、文字を（ほとんど） そのままコピーしたようなものであっても簡単に許す。そのうえ、いくつかの国（デンマー ク、スウェーデンとイギリスを含む) は、法令の例外を通してよりもむしろ総体的なライセ ンス計画（場合によっては、公平な取引と結合される）を通して EU 著作権管理の教育関連 の面を実装する。大まかに言うと、状況は大部分の国で米国よりも簡単なようである。 
白書の主要な狙いがデジタル材料の教育的な使用に対する障害を結び付けている一方で、 若干の方法は「適度なバランス」と言われることを元に戻すかもしれないと言われる。確認 された経路の間は、内容を教育的な使用の自由の状態を改善するアメリカの法律の少なくと も少し問題な規則の改革、ユーザがコンテンツを使うことのためのセキュアなライセンスの 必要性を分析することを助け、必要に応じてそのような権利保証で援助するテクノロジーに 対するより大きな依存、そして Creative Commons のようなより公開されたライセンスモデル の下でのコンテンツの更なる配布をする。このように、妨げがない教育的な使用が利用でき る内容の量を大きくする。

\section{権利を取得することによる実際的な困難}

インターネット上で第三者材料を利用した公開されている教育的な資源の前に、著者また は出版者は、これらの材料を使う権利があることを確認しなければならない。クリアランス プロセス一いつか、その複雑さのため、「許可迷路」と称される一はユーザに以下のことを 必要とする：

a)許可が必要かどうか立証する。それは時々高度な法的分析を必要とする。

b)適当な権利所有者を見付ける。それは時に簡単で、時に難しい。

c) 潜在的収益が交渉に係わるのに十分でないかもしれず、法的権利所有者が時に小さな 教育的な使用を無視するので、難しくなりうる許可に同意する。

d)非常に高価になりうるライセンス料を支払う。

e)教育的な利用者がコンテンツを保護するためにデジタル著作権管理システムを利用す るといった要求のような他の条件と制限を実行する。

Fisher and McGeveran（2006）が指摘しているように、「トラブルは、これらの点のどれで でも起こりうる」。全ての試みのための費用のほぼ半分のケースで、第三者コンテンツの使 用のための権利保証に関連した困難と経費が大部分であることは、OECD プロジェクトの一 部として実行される事例研究から明らかである。

\section{オープン教育資料(OER)の商用利用}

Box 5.1 で解説されたように、クリエイティブ・コモンズ・ライセンスを使っている著者ら は 4 つの付加的なのライセンス状態の中から選択をすることができる。その一つは非営利な 条項である。このオプションは他の人に対し、非営利の目的だけを除けば、それに基づく著 作物と独創性のない著作物をコピーし、配布し、展示し、実行する許可を与える。Creative Commons は、以下のようにしてこの条項を説明している： 
付与されたいかなる権利も行使してはならない…それが主に商業的な利点や個人 的な金銭補償を目的とするいかなる場合であっても。

これは、誰かが営利目的のために著作物を使いたいならば、それが著作権所有者の許可を 得ている必要があることを意味する。この条項は、Creative Commons を利用している全ての 著作権所有者のおよそ 3 分の 2 に利用されている。しかし、「商用利用」を設置することの はっきりした理解がない。Creative Commons の当初の信念はコミュニティが彼ら自身の定義 を造るように、「非営利」という言葉が未定義のままにされなければならないということだ った、そして、必要に応じて、償還要求はその言葉が意味したものの標準を決めるために裁 判所で行われる。異なるコミュニティがその言葉の彼ら自身の理解を作ったにもかかわらず、 各々のコミュニティが他のコミュニティの定義を必ずしも尊重するというわけではなかった。 その代わりに、例えば、非営利が全く、お金が著作権保護された著作物と関連してどこでも 取引されることができないことを意味すると思っている「フリーでオープンソースなソフト ウェアコミュニティ」のメンバーは、学校がコースパックのために課金することができるよ うに、教育コミュニティのメンバーが非営利を定めるべきではないということについて譲ら ない。

これは、教育コミュニティにおける許可を与える多くの人たちの活動が非営利な言葉の下 で許されると思っているという事実にもかかわらずに存在する。この矛盾は、Creative Commons に、異なるコミュニティにおける非営利の定義の一致に取り組み始めさせた。

Creative Commons が非営利を定義する際に取り組む難問はこの言葉の意味を認める時、裁判 官が許諾者の意図に目を向け、そして、おそらくまた、その言葉の意味や工業的な習慣を被 認可者が理解したものに目を向けるということだ。しかし、それは Creative Commons のその 言葉の意味の見方を考慮しそうにない。指針の草案を出すことがよりよくユーザにとって何 が許された非営利な使用を構成するかしないかについて理解するのを援助するかもしれない にもかかわらず、これは Creative Commons には非営利の使用が意味するものの上に最終的な 決定権があることを意味しない。指針の草案は、とりわけユーザが個人または非営利の教育 機関や図書館のような「許される非営利利用者」であるかどうか、著作物が広告において使 われるかどうか、お金が著作物と関連して提供されるサービスと引きかえに取引されている かどうか、そして、最後に、どんな派生的な用途がその著作物でできているかを見る。

異なるコミュニティには非営利な条項の異なる理解があるという事実を例示する。非営利 のものによる同じ著作物の利用が商業的でない、Creative Commons によって出される指針で は会社による非営利の認可を受けた著作物を使う自由が商業的であると思われることになる 一方、一営利会社はそのような素材を再利用するべきではないという高等教育機関が確立し た意味一M I Tからの類似した指針は、営利を目的とする会社が非営利な条項で素材を使う かもしれないとしている。4

\footnotetext{
${ }^{3}$ See http://creativecommons.org/weblog/entry/5752

${ }^{4}$ See http://ocw.mit.edu/OcwWeb/Global?terms-of-use.htm\#noncomm
} 
非営利な条項に関連したもう一つの問題は、それがコンテンツの再利用をより難しくする という事実だ。条項は、規制をそれを若干の他の許可（特に独創性のない著作物が原作と同 じ状況の下で認可されることを義務づけるもの）の下で認可される素材と相容れなくする著 作物に適用される。Creative Commons ではこの条項は「share alike」と呼ばれている。ライセ ンス同様、ソフトウェアのオープンソース化の運動において、「copyleft」と呼ばれている。

Creative Commons の下で「share alike」ライセンスとして認可された商用規制のないライセン スの著作物はそして、Creative Commons の下で認可される非営利の内容と結合されることが できない。非営利な条項の批判者は、条項が 2 つ意味で有害であると主張する。教育にお いて無料コンテンツの成長に対する重大な障害を生じさせ、再利用を制限することによって 多くの内容をしまい込み、無料コンテンツに価值を与えている新しい経済モデルの発展を遅 らせる(Möller 2005)。それが著作者の著作物を利用しようとしているどんな会社でも無料で 誰でも利用できる付加価值を作らなければならないことを意味しているという同じ状況の下 で利用できるようにされることをどんな独創性のない著作物にも要求するので、「share alike」 条項はより良い選択であるかもしれないと言う。その一方で、他の許可状況より互換性に対 する多くの障害を提供しながら非営利な許可を選び出すことが公平でないと言いえるだろう。 現在、それが最も討議されたライセンスであるという事実が残る。

異なるライセンスのもとで認可される材料またはツールの予想外の不適合性（常に残る非 互換性を意味する)または同じライセンスの異なるバージョンの問題は、最近の重要問題だ。 専門語と法律語の増加したインターオペラビリティは、OER 運動の成長のための基本的な重 要性です。Creative Commons プロジェクトはインターオペラビリティチャート（彼らのウェ ブサイトで利用できる）を考案し、Creative Commons のライセンスオプションのどの組合せ が一緒に機能するかを示した。問題を他のライセンスとのインターオペラビリティで圧倒す る彼らの戦略は、世界中からライセンスの専門家の会議を作ることである。この板は、許可 管理者からの提案の上の類似した無料のライセンスが、互換性を持つと考えられることがで きる手順を確立する。ライセンスが互換性を持つと考えられるならば、Creative Commons は コンテンツと関連する自由を表すためにメタデータを加え、コンテンツと関連する自由を説 明するために、Commons Deed とリンク寸る。それから Creative Commons はフリーライセン スの連合の中でのようなライセンスを保証する。

\section{著作権問題の認識不足}

テキストの公表、消費と配布が物理的なメディアによって調停される間、研究者は著作権 の搾取を支えたライセンスをほとんどの場合知らないままにとどまっていた。インターネッ トと他のデジタルメディアは、これを変えた。出版と生産ツールに、そして、本または印刷 のような物理的なモノよりむしろ短命なデジタル製品にアクセスし、アクセスの許可を与え ることによって教師と同様に研究者は、今までになかったライセンスで相互関係を有する。 そしてほとんどの場合、それらは、準備ができていないか、厄介なライセンス手順と関わる 気がないということである。 
多くの研究者が彼らの著作物を共有したいと思っているもかかわらず、彼らはしばしば全 ての彼らの権利を失うことなく実行する方法に関してためらう。著作権を保持することの正 反対は、パブリックドメインに仕事をリリース寸ることだ。これは、著者が権利を保たない、 そして、誰でもどんな形であれ、そして、いかなる目的のためにも材料を使うことができる ことを意味する。たとえこれが時々一部の人々のための選択肢であるかもしれないとしても、 著者が、例えば第三者が彼の同意なしで材料の商用利用をするのを止めるために、彼の著作 物にかかる若干の権利を保持したいと思うことは珍しくない。英国の RoMEO プロジェクト

（Gadd, 2003）は、彼らが著作物にどんな権利を保持したいかについて、542 人の研究者の間 で 2002〜003 年に調查を行った。大多数（60\%以上）は、第三者のために喜んで表示、印刷、 保存、抜粋、そして、寄贈するとしたが、彼らを著者とし全てのそのコピーがとても正確に ことば通りの状態にしておくことを望んでいた。55\%は、彼らの著作物の使用を教育的で非 商業的な使用に制限したいと望んでいた。RoMEO の報告では、著作権法によって研究報告 に提供される保護が大部分の研究者によって必要とされているものを上回ると結論した。こ れは、順番に、機関が研究者と教育者に著作権法に関する訓練を提供する必要を示した。才 ープンコンテンツライセンスは、著者に確保された権利を、許可され統制された共有の方法 により提供することによってこの問題に対応するために開発された。

RoMEO プロジェクトは、41\%の著者が完全に事の重大性を理解することなく「自由に」著 作権を出版者に譲渡することも示した。OECD の質問書と事例研究からの調査結果は、学習 資源を生産している教育者と研究者の間でオープンライセンスを使うことの重要性と、機関 または政府機関からのこの久陥を受け入れる試みに関しての認識が低いことを示す。これは、 著作権問題とライセンスに関する認識を上げることがオープンカルチャー運動のための重要 な挑戦であるという仮定を強化するようだ。おそらく、高等教育機関からの活発なアドバイ スと支持と共に、個々の著者が保持したい権利だけを保持するより方法よりも簡単なものさ え必要だろう。オーストラリアの 7 つ大学の比較は、オープンアクセスアーカイブへ研究 記事を研究者が単に任意に置くだけに頼ることがおよそ $15 \%$ の貢献に終わることを示してい る以前の国際的な研究を支持する (Sale, 2006)。研究結果を実際の著者に関連するオープンア 一カイブに置く必要条件は、非常により高い設置率で方針結果を裏づける。

2006 年 6 月に、マイクロソフトが著作権を放棄したライセンスのツールを発表した点に注 目寸ることは励みになる。そして、それは Microsoft Office アプリケーションで作成される著 作物に対して簡単にクリエイティブ・コモンズ・ライセンスの適用を可能にする。 


\section{3 政策勧告}

Fisher and McGeveran（2006）に加えて、権利保持者と公共利益の間の適当な釣合いを回復 するために行動を要求している他の人がいる。芸術、創造的な産業、人権、法律、経済学、 科学、テクノロジー、公共部門と教育からの専門家の国際的なグループは、アデルフィ憲章 と呼ばれる、テストあるいは知的所有権の上で法律を可決する前に考慮する議員のために、 基本的な規則の集合を開発した。憲章は、以下を述べる：

この 30 年にわたる法律の幅、範囲と期限の拡大は、現代の技術的で経済で社会的 な傾向と急進的に外れている知的所有権体制に終わった。これは、一連の創造力と 我々と将来の世代が信頼する革新をほのめかす。(http://www.adelphicharter.org)

知識へのオープンアクセス (OAK 法) プロジェクトの一部として、Fitzgerald 他 (2006)は オーストラリアの学術的研究領域の中でオープンアクセスの著作権管理のための法的枠組み に関する the Australian Department of Education, Science and Training のための行動政策と推奨 を展開した。そして、それはまた、OER 運動に役立つ。彼らは各々の機関がオープンアクセ スに関する政策を作成、公開し、はっきりその目的とこの意味で素材を提供することに対す る興味を宣言することを勧める。テンプレートガイドラインとモデルドキュメントは、オー プンアクセスシステムの設立と管理で機関を援助するために開発されるべきであり、そして、 以下を含むべきである。

・ 機関のオープンアクセス方針の開発に関する手引書、これはオープンアク セスの異なるモデルを概説し、オープンアクセスによって利用可能となる 素材のカテゴリ、どのような人々がアクセス寸る権利を与えられているか という見地からのオープンアクセスの範囲及び素材にアクセスし再利用で きる権利の限度を決定し検討する手段を提供する手引きとなるもの

- 各々のオープンアクセス方針の説明的な声明が付いてくる典型的な組織の オープンアクセス方針の例

- 正式に、オープンアクセス方針の適切な進行管理を確実にするために、責 任を機関の自治機構の中の適切な部署に割り当てる際に考慮される問題の 説明

・ 著作権の運営とオープンアクセスシステムを構築することの契約の説明

さらに、権利がリポジトリとエンドユーザによって運営される権利は関連した集団（また は「投資家」）の間の法的関係を通して確保されるということを確実とすることが重要だ。 著者や出版者と同様に、投資家は資金提供組織、著者の雇い主、デジタルリポジトリとエン ドユーザを (その中に) 含める。集団の間のあらゆる契約の条件と共に、素材を使う権利は、 著作権法の原理の適用によって決定される。誰がリポジトリに置かれた学術的な材料を使う のを許されるかとそのような素材の許された使用の範囲について確かめるために、いろいろ な投資家と彼らのそれぞれの役割を特定し、彼らの間の法的関係を記述し、著作権収益がど のように割り当てられるかについて理解することは必要であろう。 
OAK 法の報告は、オープンアクセスシステムを確立しているか、管理している機関に実際 的な援助を提供するために、テンプレートガイドラインが高等教育機関と研究の環境の関連 した投資家のそれぞれの役割と、どのように彼らの間の関係が決定するために相互に作用す るかを記述して展開されなければならないと提唱する：

・ オープンアクセスチャネルを通して高等教育機関及び研究結果が利用でき るようにされるべきであるかどうか

・もしそうならば、利用できるようになっている素材の種類またはカテゴリ

・ そのような素材が利用できることになっている範囲（つまり素材を入手し て利用することを許された権利の範囲）

・ 確認された資料へのアクセスと使用の望ましい範囲が、どのように特定の 機関にあてはまっている法的枠組みの範囲内で確保されることができるか

諸国間の異なる政策レベルの間での責任の違いを考慮して、これらの勧告は、OERの開発 と活用を促進する方法を模索している機関や国のモデルとして役立つであろう。 


\section{第六章}

\section{OER 企画における持続可能性 (sustainabi lity) の問題}

持続可能性の問題は、あらゆる OER プロジェクトにとって中心的な課題である。本章では、 プロジェクトを企画するいろいろ異なった方法、コスト回収モデル、コストと他の問題の重 要な交換、OER プロジェクトが長期間存続するための考慮すべき要因などの再検討をする。 


$$
\text { オープンエデュケーショナルリソース（OER）が増加するにつれて、それらのプロジェク }
$$
卜をいかに長期間維持するかという問題が重要になっている。ケーススタディによれば、大 抵のプロジェクトは所属する機関や政府の資金、もしくは個人の寄付金からなんらかの形で 初期資金を得ている。さもなくば、それは持続可能性を全く考慮していないボランティア精 神の結果である。しかしいったん初期資金が停止すれば、運用資金を賄うための代替手段を 早急に見付けなければならない。持続可能性は経済的な問題のみではなく(もちろん経済的な 問題も依然重要であるが)、技術的な保守作業、組織化、コンテンツ・モデルやスケーリング の可能性など、などの数多くの問題を含んでいる。これらの問題や他の問題を個々の試みに 対してどのように衝撃を与えるかは、各プロジェクトの規模及びその機関的・財政的な基盤 に非常に依存している。当局は持続可能性の問題に関して David Wiley に論文執筆を委託し た。以降の章はこの論文に多くを負っている。Wiley の論文はまた、その内容のいくらかを Dholakia と Downes の論文に負っている。これらの論文もまた当局に委託されたものである。 全ての論文はこのプロジェクトのウェブサイト(www.oecd.org/edu/oer)から得ることができる。

前出の図 3.2 で示したように、プロバイダの種類を分類することは有効である。どのよう に持続可能性の問題を理解するかに影響を与える次元は、最低でも三つ存在する。すなわち、 運用規模の大きさ(大もしくは小)、プロバイダの種類(機関もしくはコミュニティ)、製作プロ セスにおける利用者の協調度(co-production モデルもしくは producer-user モデル)である。図 6.1 には、co-production モデルと producer-user モデルを使った機関的な試みの例と、同様に二 つの異なるモデルを使ったコミュニティ的な試みの例が図示されている。

LabSpace とは、イギリスにおける Open University の OpenLearn Initiative の一部である。こ れは、学習リソースの co-production モデルにむけて開始中の機関的なプロジェクトである。 OpenLearn の別の一部である LearningSpace は、オープンコースウェアモデル上の全てのプロ ジェクトと共に、図の右下の領域に位置している。このモデルは大学で教えられた講座を使 用するため、機関的な援助を必要とし、また一般的にこれらの講座は教員によって作成され 他者によって利用されることになる。Open Course Initiative はほぼ専門指向のコミュニティを 主催しており、オープンコンテンツを作成、評価、利用している。そのウェブサイトによれ ば、それは「オープンで再利用が可能な学習資産を作成するという共通の目的を持った、教 員・研究者・生徒によるコラボレーション」である。Stephenson(2005)は、これを「オープン コンテンツを作成・使用・向上するような人々が生態系を形成する」ような生態系として表 現している。対照的に、MERLOT は、コミュニティ的であるがそれほど学習リソースの協調 的生産（co-production）を志向していない。これは co-production モデルというより、仲間が 交換・共有を行う場所である。 


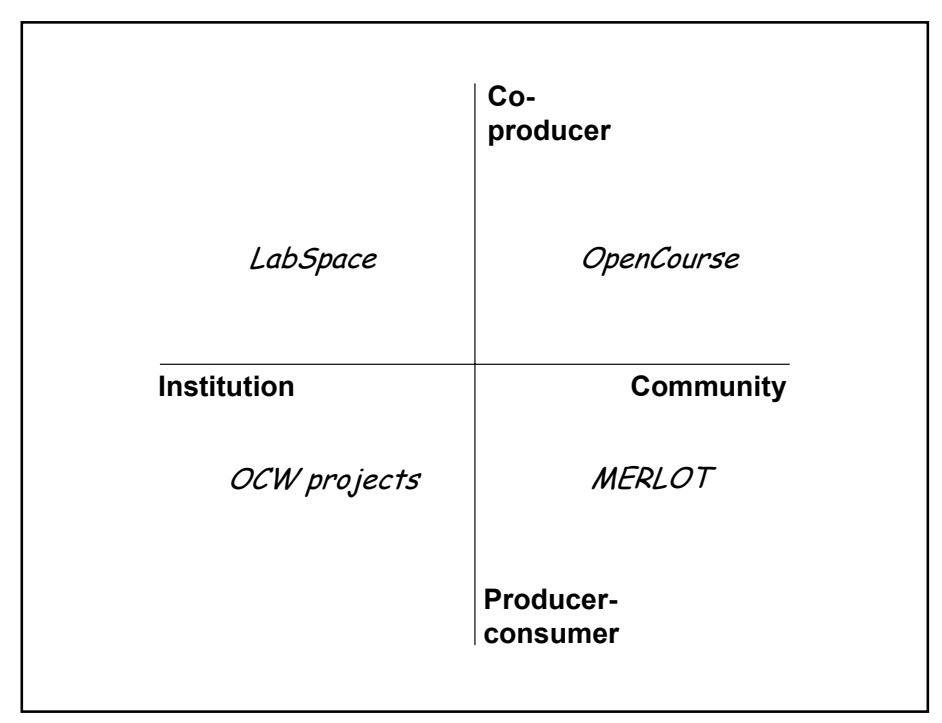

図 6. 1 Co-producition モデルを使ったプロジェクト人事例

Downes(2006)が示したように、producer-user モデルはより中央集権的であり、プロのスタ ッフを伴うようである。このモデルではより質的・量的な統制が可能であるが、そのかわり により高いレベルの資金を必要とする。一方 co-production モデルはより非集権的な管理体制 によるようである。これはパートナーシップを伴うかもしれないし、ボランティの貢献を伴 うかもしれない。

高等教育機関の間の競争激化と、節約の必要性及び新たな収益モデルの模索の必要性は、 機関が OER に興味を持つ理由を幾分か説明するかもしれない。いくつかの機関が OER プロ ジェクトを機関自身を支える方法であると見な寸例さえある。その方法とは、プロジェクト のみならず機関自身にも利益をもたらし、機関のコストを削減し、入学者を増やすことで機 関の収入を増大させる、というものである。更に、OER プロジェクトと密に連携することで 広報戦略を再考する機関の例もある。そのような例の一つに Rice University がある。 Rice University は OER プロジェクトの Connexions と非常に深く結びついている。Rice は 10 年間 休眠状態であった大学の機関誌を再び立ち上げた。彼等は、その新しい技術がマルチメディ アを使ってオンデマンド(on-demand)型の独創的な広報物を発刊する新しい手法をもたらす と考えている。Connexionsによって開発された技術と出版プラットフォームを使用した最初 の e-publication は2006 年 10 月に発刊された。Rice University Press は他の大学機関誌とも共 同で作業を行っている。

Wiley(2006b)が述べるように、維持可能性はしばしばプロジェクトが運営を継続する能力 であると見なされている。たしかに継続性は、維持可能性が意味するところのうちの核心的 な部分である。しかしながら、無価值なものを生産するプロジェクトや人員を単純に継続さ せようとする策謀は重視すべきでない。従って維持可能性の定義には、期間の長さの面に加 え、目標の達成の面を加えるべきである。以降は、維持可能性は OER が目標を満たしながら 
継続する能力であると定義される。OER は二つの固有の種類の継続可能性を模索すべきであ る。

・プロジェクトは OER の製作と共有を維持する方法を見付けなければならない。

・同じくらい重要に、エンドユーザ(教員と学習者)による OER の利用と再利用を 維持する方法を模索しなければならない

彼は最初の課題は二つの部分を考慮すべきであると考えた。a) OER の製作の維持、b) 資 料の共有の維持である。最初の部分は、OER の製作は人的な資源、ワークフロープロセス、 そして支援技術を必要とする。少なくとも、誰かがコンテンツを保存し、デジタル化し、著 作権問題をチェックして解決し、最終製作物としての質的な保証を提供しなければならない。 これら全てはコンピュータ、ネットワークへのアクセスそして一つ以上のソフトウェアツー ルによる支援を前提として行われなければいけない。人的な時間、ワークフロー方針の改善、 コンピュータの購入、ネットワークとの接続、ソフトウェアの購入と管理などにかかわる現 実的なコストが存在する。これらの現実的なコストは維持に関わる課題の一部である。二つ 目の部分では、仕上がった OER のコピーをエンドユーザに配布しなければならない。これは インターネット上でのデジタルコピーの配布、ハードディスク・DVD・USB メモリによるデ ジタルコピーの配布、あるいは印刷された資料の紙のコピーを意味する。それぞれの配布方 法には、オンライン上でデジタルコピーを配布するための帯域や、物理的なメディアや紙の 在庫・複製・輸送コストといった現実的なコストがかかる。これらの現実的なコストを満す のが OER プロジェクトの維持の課題のもう一つの部分である。

第二の課題は OER プロジェクトがその目標を達成できるかどうかについて考慮しなけれ ばならない。プロジェクトは教員や学習者が使えないような資料の作成・共有に数年を容易 に消費してしまう。可能であれば、資料はハードウェアや OS のプラットフォームを問わず に良好に運用できる形式で、また個別の調整が可能な方法で調達されるべきである。しかし、 MIT の OCW プロジェクトで議論されたように(d'Oliverra, 2006)、もともと資料がデジタル出 版のためにつくられていない場合、いわゆる PDF 形式のみで可能な限り多くの資料を出版す ることと、調整と再利用により向いているが多くの労力を必要とする形式に変換することの 間に、明らかなトレードオフが存在する。XML はコンテンツの表示、操作、再目的化に最大 限の柔軟性をもたらすインターネット出版のための新興の標準である。しかし上質な XML 文書の作成には、適切な符号化及びコンテンツの構造化を保証するためにコースと科目との 親和性が必要であり、そのような作成は自動変換ツール単独や、コンテンツに関する知識を 欠いた転写者には完遂できない。MIT OCW プロジェクトによる結論は以下のようになる。

コースで使用されたオリジナル教材が XML やXML に容易に変換できる構造によ って OCW に投稿されない限り、大半のコースではXML による出版は生産時に耐 え難いレベル(二倍か、それ以上)の労力を追加する(d'Oliviera, 2006)。

ユーザは資料の効率的な再利用のために技術的なツールを必要とするかもしれない。彼ら はまたローカライゼーション(localization)を可能とする訓練や例示をも必要としている。最後 に、多くの OERで使われている「継承(Share-Alike)」型のライセンスを遵守するためには、 
ユーザは改変物を置く場所や、改変物が置かれた場所を他人に伝える場所を必要とする。そ して再び、容易に編集可能でプラットフォームを問わない方法で、また資料のローカライゼ ーションのための新しいツールを提供し、またローカライゼーションのプロセスに関する訓 練を提供し、そしてユーザに「継承」の責任を果す仕組みを提供するのに、コンテンツを調 達するための労力に関連する現実的なコストが存在する。これらの現実的なコストを満すの は OER の課題のもう一つの部分である。

プロジェクトが目標を達成しつづけるために、現実的なコストをいくらか調達しなければ ならないのは、必ずしも OER に固有のものとはいえない。しかしながら、「原価回収」の仕 組みなくして、これら全ての努力の結果を無料で譲るという断固たる決断は、OERに固有の ものであるといえる。金銭の調達方法なくして、年々コストに対応しながら必要な資料を提 供するプロジェクトとはどのようなものだろうか?

\section{1 OER 企画の組織化}

インターネット上におけるボランティアによるコミュニティを理解することへの興味は 年々高まっている。今までのところ、大半の注目はオープンソースソフトウェアコミュニテ イになされていたが(Weber, 2004)、Benklerの「ピア・プロダクション(peer production)」の分 析やコミュニティベースのコンテンツ開発、Wikipedia 現象における多数の記事の分析(2005, 2006)は、ボランティア的で協調的なコンテンツ開発への増大寸る興味を示した。コミュニテ イベースの開発、あるいはピア・プロダクションにおいて、人々を巻き込み、そしてその仕 事を協調させる原理は興味深い問題である。Benlker(2005)はオープンソースソフトウェアの 開発モデルの成功の重要な要因は、多くの人々が小さなモジュール(module)に貢献できるこ とであることについて議論した。多大な時間をかける必要のない課題はより魅力的に見える。 多くの人々が関与すれば、それぞれの負担はより軽くなる。コンテンツの小さなモジュール に貢献できる可能性は、Wikipedia が成功したが一方で姉妹プロジェクトの Wikibooks が Wikipedia ほど成功していない理由を明らかにしている。これは本の章を十分小さな部分にわ けることが不可能であるという事実のせいかもしれない。もし小さな断片にわければ、章に 対する個々の貢献を集める作業は、本を全て一人で書くことに比べおそらく時間を無駄にし てしまうだろう。

組織的な作業の面に関しては、ボランティアの共有に対するモチベーションを認識し促進 する組織形態が求められる。従って、Downes(2006)が議論するように、ボランティア組織に は明確で総合的な視野、戦略、参加者に対する役割が求められる。例えばそのようなオープ ンソースソフトウェアのコミュニティに Apache Foundation がある。それは、それぞれの製品 に対して責任を持つ部門長がボランティアの人員を組織化し、ボランティアは「ディベロッ パー」、「コミッター」、「ユーザ」などの異なる役割をつとめるという、独自形式の明白 な能力主義社会である。重要な開発を行なっているメンバーは、「プロジェクト管理委員会 メンバー、すなわちプロジェクトの進展とコミットしたことの証しのために選ばれたディベ ロッパーもしくはコミッター」になる(www.apache.org)。 
co-producution アプローチと producer-user アプローチは異なる作業の組織化を必要とする。 例として、使用する学習教材の開発と選択について考えてみよう。MERLOT は、例えば、 producer-user アプローチを使用し、ボランティアの貢献を勧めている。しかし彼等はまた、 可能な限り共同的なコミュニティによって教材を専門的に查読している。それは学術的な論 文誌にとても良く似ている。開発と選択の過程は、従って、形式化され、また良い程度に集 権化されている。それは誰もが自身の貢献の投稿を許されるようなプロセスと比べると、速 度も遅いようだ。MERLOT においては、投稿された素材の、わずか 14 パーセントのみが査 読されている(Hanley, 2005)。この背景とは対照的に、Downes はワークフローは再組織化が なされていること、学習者のためとみなされていないこと、またある種の維持可能な(あるい は商業的な)計画に支援されていることが必要であると主張している。それどころか、ワーク フローは「学習者が自身のために何かをする時、実際に、全ての学習行為がその過程に存在 する」と考察されるべきである。彼はまた、Wiley(2005)の以下の文章を引用している。

「維持可能性とスケーラビリティは人々が自身のためにすべきことを他者に頼っ てしまう時にのみ、問題となるように感じられる。スケーラビリティと維持可能性 は人々が自分自身のために何かをする時、より容易に実現する。オープン教育サー ビスの集権化は、スケーラビリティと維持可能性をより縮小する。非集権化はスケ ーラビリティと維持可能性をより拡大する。Wikipedia は二人の従業員と複数の言 語における百万以上の記事を持っている。オープン教育が本当に人々の生活に届い てその恩恵を与えようとしているのであれば、我々はこの教訓に学ぶ必要がある。

協調的生産の観点に立てば、手頃で便利な素材を即座に提供するような OER を維持可能に するためには、OER をボランティアと報奨、コミュニティと協調、生産と共有、分散的な管 理と制御などを含む大きな構図の単なる一部と見なすことが必要であると結論できるかもし れない。

\section{2 コストと収入モデル}

OER プロジェクトを運営する実際のコストは恐らく様々である。イギリスの Open Universityによって始められた OpenLearn は、最初の二年間は一年あたり 500 万米ドルの予算 を持っている。MIT OCW の予算は 430 万米ドルと 29 人の人員を持っている。スタンフォー ド哲学百科(Stanford Encyclopedia of Philosophy)は一年に約 19 万米ドルを消費し(Zelta, 2005)、 Utah State University の OCW の試みは一名の常勤プロジェクト指揮者と 5 名のアルバイト学 生補助者及び 12 万 7 千米ドルの予算を持っている(Wiley, 2006)。 University of the Western Cape in South Africa における OCW プロジェクトは 3 名の人員と一年に約 4 万 4 千米ドルの予算で 運営されている。他の多くのコミュニティベースのアプローチによる試みは恐らくより少な い予算を持ち、コミュニティのメンバーのボランティア作業により多くを依存している。

金銭以外の実際のコストによって資料を賄えることを明らかにするのは重要だが、それで も多くの試みでは少なくともいくらかの時間を調達する必要がある。この目的のために、多 くの異なる資金調達モデルが考えうる。Dholakia(2006)と Downes(2006)は調査すべきモデル の種別を分類した。 
・ 置換 (replacement) モデルは、オープンコンテンツが他の用途を置換し、 その置換の結果としてコストの節約の点で利得が得られる。このモデルは、 置き換えるのと同じ量の資料しか生成できないという本質的な限界がある。

- 基金・寄付・寄贈（foundation,donation,endowment）モデルでは、運営 のための基金が財団のような外部の関係者によって提供される。開始初期 のモデルは大抵長い期間実行可能ではないようだが、それが政府の支援モ デルに変換されれば、それが長期間続く国もある。

- 区分（segmentation）モデルでは、供給者は、無料の資料と同時に、「付加 価值型」サービスを課金ユーザ区分に提供する。例えば、紙のコピーや、 訓練とユーザサポート、専門家への質問サービスなどである。このモデル は、変換モデルと同様、現在の教育業界では最も良く使われている。

- 変換 (conversion) モデルは、無料の提供が利用者を有料の利用者に変換 するというモデルである。

・ ボランティア的支援（voluntary support）モデルは、寄付金調達のキャン ペーンに基づく。このモデルの別の形態では、興味を示す組織あるいは個 人の仲間の集りに、初期資金か年間の基盤として一定の金額を寄与するこ とを勧誘する。

・ 貢献者-支払い（contributor pays）モデルでは、貢献者がその貢献を維持 するためのコストを支払う一方で、提供者は無料を実現する。基本的なオ ープンアクセスモデルはまた、OER プロジェクトによって使用されるかも しれない。

他の選択肢には広告やスポンサーもある。個々の試みはそれぞれ唯一のものであるため、 一つのモデルで全てに適用できるようなものはない。そのかわりに異るアプローチが局所的 なコンテキストで有効であることを発見する必要がある。Dholakia(2006)は試み同士での競争 激化がより強いブランドを開発する必要をもたらしたことも強調している。コミュニティの 「マーケティング」によって、ユーザは Web サイトにより強く結びっくことができ、そのた めにマーケティングは重要であるといえる。更に、教育機関はコミュニティから Web サイト 上では何が動き何が動かないかを学ぶことができる。また、それは急速な普及の可能性もも たらし、強力なコミュニティはユーザの振舞いに影響し、ユーザがリポジトリに復帰する確 率を増加するであろう。 


\section{3 OER の持続可能性に関する政策問題}

様々な政策が、OER プロジェクトの活動を可能にも妨げもする。社会モデルはボランティ アワークと熱心な人々の上に成り立っているため、持続性の維持は、社会の繁栄と成長を妨 げる障壁を解体する場合のような金銭的問題ではない。試験的な政治行動は、現在の知的所 有権の政治活動の代替となるものを発見し、寄付者が公共の Initiative のみならず大まかに構 成された社会に対しても寄付寸るように考え方を変化させることができる予定である。

機関はこのようなプロジェクトを調整することができる一方で、著作物を自発的に共有し てきた教職員はこれらのプロジェクトの成功の影に第一に隠されてきた。Wiley(2006)による と、高等教育機関が尋ねることの出来る政策に関する最も顕著な質問は、教職員に OER Initiative に参加する動機を起こさせるものは何であろう、という質問である。教育において 透過性と責任の両方を改善するアクションは、教育ポートフォリオや同様の設備を tenure 過 程の一部として実装したり、教育ドキュメントを優秀にする必要性の一環として、少なくと も一つのコースを OER フォーマットに変換すべきだと促がすことである。

高等教育における OER の勝者に対して、政策方針に関する次に顕著な質問は、「ひとつ以 上の講義に対してオープンアクセスを望む教員に対して、現在の政策方針のうち何が障害と なっているのか」という質問である。このような政策の例として、機関が教員により作成さ れた知的所有物を支配しようと主張することで、教員たちが tenure と政策の前にオンライン 学習活動に従事するのを妨げることがある。

国際的・地域的な視点から見ると、OER プロジェクトに従事する高等教育機関への助成の 増加は未だ一般的でない。既にこの目的に割り当てられた助成金を使うための明らかな許可 を機関に与えている政策はプロジェクトへの関与を奨励している。教員の関与を促進しうる、 もしくは少なくともそれに対する障害を減らすことのできる機関の政策に関する国際的・地 域的対話は役立つであろう。

\section{4 継続中の OER プロジェクトに関する諸課題のまとめ}

結果として放棄されてしまうプロジェクトを続けるのは困難である。この結論には見込み がない。しかしながら、Wiley(2006)による次の事実に対する詳細な考察により、OER プロジ エクトが何年もに渡り自身の目標を達成しょうと、長期間の活動を続けていく機会が増える であろう。

1. OER プロジェクトは、自身の目標を明確に述べなければならないし、またそれらを しっかりと捉えていなければならない。もし持続可能性がそのプロジェクトが目標 を満たすための継続的な能力であれば、目標の明確な理解なしでは OER のプロジ エクトは持続しない。

2. 次に述べるいくつかの決定は連結してなされなければならない。プロジェクトの目 標という文脈では、OER プロジェクトは以下について決定しなければならない。 
3. 組織のサイズ、構造と組織の中央集権化の度合い。より小さい組織、より分散化さ れた組織は維持費は低いが、短い期間で多くの資源を作り出す能力は低くなりがち である。また、典型的な、事前に決められた方向へ向かう可能性も低くなりがちで ある。

4. 提供する資源の種類と、資源を共有するためのメディアフォーマット。プロジェク トが資源を蓄えるのに最も簡単なフォーマットであっても、一方でユーザが資源を 適応させようとすると非常に難しいフォーマットであることも時おり起こりうる。 また一方では、資源がもともと電子的に公開されることを想定してデザインされて いなかった場合に、できるだけ多くの資源を公開しようとすることと適応と再利用 により適したフォーマットを利用することの間にはトレードオフが生じる場合も ある。

5. プロジェクトが目標を満たす上で最も助けとなるエンドユーザの種類。ユーザがコ ンテンツを再利用する際にどれほど明白なサポートを提供するかを決定しなけれ ばならない。これらのツールに対するリンクはサイト外のコンテンツとなるだろう か?これらはウェブサイト自身と統合できないか?もしこれらが集中化されるのな らば、サポートはいつでも提供できるが、その費用は高くなる。もしボランティア のネットワークを越えて分散化されるのであれば、サポートのコストは低くなるが いくらか信頼性がなくなる。

6. できるだけ多くの参加者を約束するために、金銭的でない動機を見付け、利用する こと。学生ボランティアを創作活動や、ユーザのグループを超えてサポートの責任 を分散化させることや、参加者に組織的に報酬を与えることは、全てコストの削減 につながるが、これらには何らかのトレードオフがつきものである。

7. プロジェクトの目標を満たしながらのコストの削減方法。チームを小さくしたり、 サードパーティーがライセンスを持つコンテンツに対して、ライセンスを獲得せず に置換や削除を行うためのポリシーを確立したり、オープンな発行物を現在のオン ラインのコース開発プロセスと統合したりすることは、全てコストの削減につなが るが、これらには何らかのトレードオフがつきものである。

8. 利用可能な多くの投資モデルの中から、プロジェクトが継続的に目標を満たし続け ることのできるのに十分な投資レベルに結びつきやすいものを発見すること。 
持続性において同様な国際的アプローチが Stacey と Rominger (2006)により採用されてい る。図 6.2 に示す五角形は、BCcampus プロジェクトの実験により作られた。

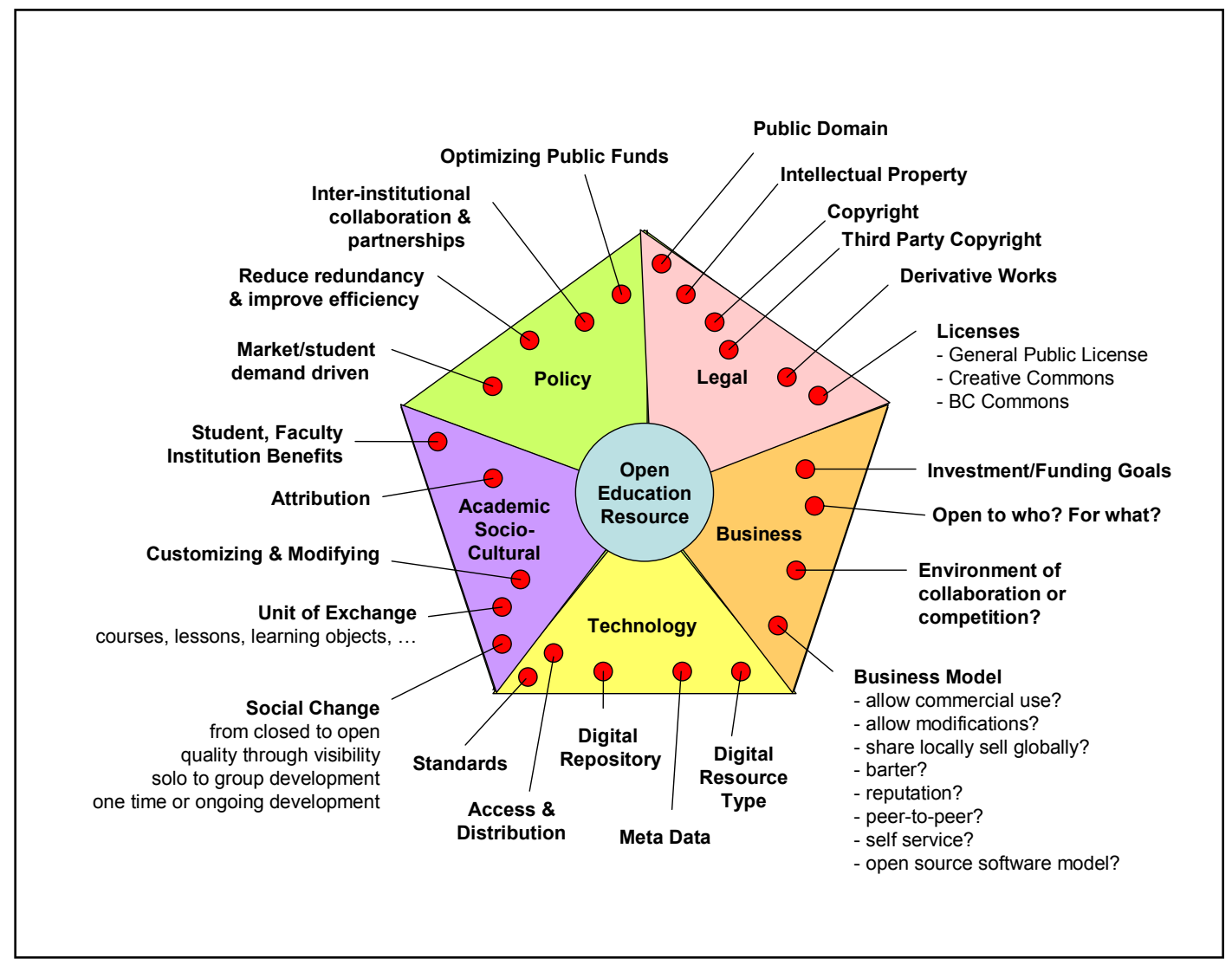

図 6. 2 オープンェデュケーショナルプロジェクトの属性と特質

(Source: Stacey and Rominger 2006)

最後に、Wiley(2006)に指摘されているように、投資モデルと国際的ポリシーのどちらも、 OER プロジェクトにおける高等教育の保証の促進には不必要かもしれない。結局、高等教育 機関に対して、参加ポリシーや利用可能なプログラム、コース、教員の情報を掲示し、公衆 がアクセスできるようなウェブサイトを維持するように奨励し要求するような国際的政策は 存在しないし、またほぼ全ての高等教育機関はこれらのサービスをウェブベースで提供する のに膨大な人的、資本的資源を費やしている。少数の、初期の適応者がこれらの情報をイン ターネットを通じて提供することの利点を示してから、他の大学は競争に生き残るために後 に続かなければならなかった。

理想的には、OER プロジェクトは、一般の人々が全ての高等教育機関に対して期待するよ うな別のサービスになり、それぞれの機関はこれらのプロジェクトに取り組むための意欲と 資源を自身の中に見付け出すであろう。その時が来るまでの間は、OERの試験プロジェクト は非常に文脈的な持続性の海をナビゲートしなければならない。 


\section{Box6.1 Creative Commons テキストの場合}

米国政府監査室(General Accounting Office)のレポートによれば、現在、アメリカ合衆国においては、学 部学生に利用される商用の教科書にかかるコストは、年間 900 ドルに達しようとしている。このような ケースでは、高等教育機関や学生自身が、商用の教科書ではなくその代用品を用いることで、金銭を節 約することができる。

Beshears の主張では、学校は、一つ以上の戦略的パートナー（例 : UK Open University）から教科書コン テンツを開発・獲得するための事業連合（比較：上述の「membership model」）を形成し、さらに、その コンテンツを、商用の教科書の代用品となり得るデジタル教科書として頒布するべきである、とされて いる(Beshears, 2005)。Bashears の試算では、1,000 機関の高等教育機関が提携することで、1機関あたり 年間 75,000 ドル程度で UKOU を「買い取る」ことが可能である（すなわち、UKOU の年間開発費用を 賄うことができる)。この年会費 75,000 ドルを各機関が授業料で賄おうとする場合、1 機関の学生数を 20,000 として、（75,000 ドルを 20,000 人で割り）1 学生あたり年間 3.75 ドル程度の出費となる。これは 現在の教科書の年間コストより圧倒的に少ない。なお、大学の図書館においては、一つの学術誌に対し 購読料としておよそ75,000 ドルを支払っているケースもある。

Bashears は、教職員に商用の教科書を OER へと転換することを促すためのローカルモデルとして、次 の三つを提示している。

1. おしやべり・・・我々がモデルを構築しさらにそのことを社会に広く伝えれば（おしやべりす れば）来訪者が現れる、ということを仮定する単純な図書資源モデル。

2. 杖 ・ ・ ・教職員に対し商用の教科書の対用品としてオープンコンテンツを利用することを勧告 する管理命令モデル。このモデルは、学生が商用の教科書を容易には購入できない発展途上国に おいて用いられる。

3. 人参・・・学生の授業料や教職員の俸給まで含めた報奨金モデル。

後者に関して、人参モデルを採用する場合には、例えば、教科書を用いる講座に対する教材手数料の制 度を設立することが可能である。この手数料は、各講座で用いられる教科書にかかるコストに基づいて 定められる。すなわち、学生が現在、平均で年間 500 ドルを 100 講座に対し支払っているとすれば、こ れらの講座に対する教材手数料は年間 500 ドルとなる。これらの講座に関しては、学生は教科書を購入 する必要はない。教職員は、自由に商用の教科書を指定することができる。もし教職員がそのように指 定した際には、指定された教科書は手数料により購入される。しかし、教職員が公開教科書事業（Open Textbook consortium）の提供するオープンコンテンツを利用することを選択した場合には、彼らは、自 身の講座に合わせ教材をカスタマイズするのに必要な分だけ俸給を与えてくれるような助成を志願す ることができる。これらの助成は、手数料の収益によって賄われる。教職員が助成を通して開発したコ ンテンツは、クリエイティブ・コモンズ・ライセンスの下で、公的に利用可能なものとなる。教職員が、 オープンコンテンツの利用を決定し、しかし助成の適用を志願しなかった場合には、その分の金額が払 い戻し金(patronage refund)として学生に返金される（すなわち、生活協同組合により分配されるものと 同様である)。

Source: Beshears (2005) 


\section{第七章}

\section{OER ヘのアクセスと有用性の改善}

本章では、品質管理、コンテンツの翻訳とローカライゼーション、障害者のための改善され たウェブアクセスなど、OER へよりよいアクセスと有用性を検討する。また、オープンソ ースソフトウェア（OSS）、OERの動向に影響を与えるオープン標準や新しい技術を利用な ど、アクセシビリティに関連する多くの技術的な問題の検討も行う。 


\section{1 OER の品質の妥当性}

オープンエデュケーショナルリソース(OER)は、その成功によりひとつの課題に直面して いる。学習教材やリポジトリが急速に増え続けていることにより、最も適切な資料や、さら にその中で最上の品質を提供するものをどのように見付けるかという問題を引き起こしてい る。そのため、効果的な検索、発見ツールが必要となる。教師や研究者にとって、興味のあ る資料は、図書館の蔵書や研究機関(federate)のデータベース、オンラインで購読する論文の 中には含まれていないかもしれない。多くの資料は、ローカルなデータベースに属しており、 インターネットを通じて利用可能ではあるが、発見することは困難であり研究者たちにとっ ては見えないことと同じである。この問題には、ちょうど図書館で図書カードが本を探すの を手助けしてくれるように、検索対象にメタデータ(データについてのデータ、対象に対する 説明的な情報)を付与することで検索ロボット(ユーザが検索インタフェースを通じて利用す る)に発見されやすくするという、技術的な解決策が存在する。しかし、対象にメタデータを 付与することは、非常に時間がかかる。またこの解決策には、よくソフトウェアプログラマ が直面するような問題がある。メタデータを付与する人は、ほかの人がどのような習慣の下 で対象のデータを利用するか知らないのである。即ち、検索というものは、メタデータを付 与する人が予想したよりもまったく異なる視点から行われるものであるということが、資料 を見付けることを困難、または不可能にしているのである。

ヨーロッパの Schoolnet が行ったプロジェクトの評価レポートでは、学習資料を直感的かつ 分かりやすい専門用語を用いて説明することが困難であることの一例を見ることができる。 彼らは、プロジェクトで用いられた資料に対して分類を行っても、その資料が教員にどのよ うに利用されるかを正確に反映したものとはならないという結論に至っている。

評価の証しという観点から見れば、ラーニングオブジェクトの使用が構成主義者 (constructivist)や高等教育の支援となりうると結論することは可能であるが、この結 果はラーニングオブジェクトよりもその教師の受け持つ教室の特徵によるもので ある可能性も高い。ラーニングオブジェクトの種類が結果になんらか(アフォーダ ンスなど)の影響を与えていることは確かである。しかし、明らかに非構成的 (non-constructivist)であったり高等的でない(non-advanced)ラーニングオブジェクト (ドリルや練習)も、教師が教材を利用する技術を備えており、さまざまな教授法を 心得ている場合には、高等的な教育の一部として用いられることがある

(McCormick, 2004 cited from European Schoolnet, 2006)。

メタデータを付ける対象の資料の大きさが小さいほど、メタデータを付ける際の問題は大 きくなる。なぜならば、資料が小さいほじ、メタデータを付与するのにかかる時間は大きく なり、また科学論文のような大きな対象に比べてその使用され方も様々に及ぶからである。 一方で、国や言語や文化を越えて利用することのできるメタデータの体系を作る研究が多く 行われてきた。異なる国や言語、文化の間で共通する分類が久けている問題は、適した学習 リソースを発見する可能性を上げるために克服するべきもうひとつの重要な障害であるから である。これに変わる解決方法として folksonomies を利用できる可能性がある。教材の利用 者に対して、使用中にその教材にメタデータを付与してもらうという方法である。この方法 
は、大きな規模のテストはこれまで行われずにいたが、Metadeta Ecolgy for Leraning and Teaching (MELT)と呼ばれるこの分野における先駆者的プロジェクトが近年 European Schoolnetによって設立された（Box7.1 参照）。

学術的教材は OAIster「自由に利用できる記事に対して容易に検索を行うためにメタデー タを利用しているサービス」を利用寸れば見付けることができる。OAIster は、さまざまな機 関の間でのメタデータの共有を容易にするために開発された。それぞれの機関は、資料の自 動収集が常に行われるようにするために、自身の持つ資料に対する情報がどのように表示さ れるべきかを定義するプロトコルを使用しなければならない。OAIster は Yahoo!や Google と 提携し、OAIster のメタデータを商用の検索エンジンでも使用可能にした。2007 年 1 月には、 OAIster は 729 の機関から得た 1000 万ものオブジェクトにアクセスできるようになった。

\section{Box 7.1 Learning Object(教材)へのメタデータに関する European Schoolnet の活動}

European Commission's eContentpus programme の資金援助を受け、インデックス付けのエキスパートによ って付けられる priori メタデータ(使用前のメタデータ)と教師、学生や機械から収集される posterioir メ タデータ(使用後のメタデータ)という二つの異なるアプローチ間の相互作用を検証する目的で、2006 年 10 月に European Schoolnet がプロジェクトを開始した。主な目的は、より広い領域でのコンテンツの利 用とヨーロッパのコンテンツ市場の発展の支援のために、様々な異なるコンテキストにおける教師／学 習者の、資料の実際の利用を反映するメタデータを付与することでコンテンツを豊かにしていくことで ある。学習教材の商用、非商用の提供者に対して federated な検索を行った結果、ヨーロッパ中の学校に 対して特別に用意した web サイトにおいて、様々な言語の 37,000 以上の学習資料と 95,000 以上の学 習資産が無料で利用可能になる。Metadata Ecology for Leraning and Teaching(MELT) と呼ばれるこのプロ ジェクトでは、教師にコンテンツに対してメタデータを付与させることでソーシャルタギングと 「folksonoies」に対する新しいアプローチが使用される。自動的にメタデータを付与するというフレー ムワークにより、メタデータの量が大幅に増大する。

The European Schoolnet は、ヨーロッパの 28 の教育省庁からなり、教育、学習、コラボレーションに関 する教育ポータルを提供している。MELT プロジェクトは、12 の教育省庁を含む 13 ケ国 18 のパート ナーが参加している。主要なパートナーにはARIADNE が、それ以外には GLOBE、MERLOT、EdNA、 MIT OCW などが挙げられる。

MELT は CALIBRATE プロジェクトと共に、Europaen Schoonet による、膨大な量の OER を学校に提供 する Learning Resource Exchange service の設立を支援する。

Source: European Schoolnet: http://info.melt-project.eu, http://calibrate.eun.org, http://lre.eun.org

OER と関連するサービスは、Global Learning Objects Brokered Exchange(GLOBE)のようなリ ポジトリによって提供されている。GLOBE は、ARIADNE Foundation、Education Network Australia(EdNA Online)、 LORNET Canada、 MERLOT、 National Institute of Multimedia 
Education(NIME) in Japan からなる国際的な連合(alliance)である。GLOBE は、全てのメンバー のリポジトリ間での検索を可能とするような、ユースケース、設計仕様、ビジネスルール、 技術を開発した。同様のサービスは、より小規模なものではではイギリスの Intute と呼ばれ るリポジトリや、オランダの DAREnet や、US based Gateway to Educational Materials により提 供されている。教材に対する検索は、普通は教材の分類や、ダウンロード数などの基準のよ うに、ある軸に沿って行われる。このような検索カテゴリを用いて検索すると、検索の正確 さと品質に関する問題が明らかになる。教材に対してあまり多くの検索結果を返していては、 最も適切かつ最も品質の高い資料を見付けることが困難かつ時間がかかるだけである。その ため、検索結果を絞り込むことで教員や学生を助ける手法や技術が開発されている。

しかし、適切さという概念は、品質という架空の概念の一側面であり、他にどのような側 面があり、それをどのように表現するのかには様々な方法がある。e-Learning というコンテ キストの中では、European Foundation for Quality in e-Learning(EFQUEL) と呼ばれるヨーロッパ の巨大なネットワークがあり、サービス提供によるヨーロッパでの e-Learning の品質の向上 と、ヨーロッパの e-Learning コミュニティの全ての管理者の支援を使命としている。彼らは、 大学や学校などの組織で品質を向上させるために、4つのステップ(要求分析、決定プロセス、 具現化フェーズ、結合ステージ)(needs analyses; a decision process; a realisation phase; an incorporation stage)から成るロードマップを提案している。

オープンソースソフトウェア(0SS)のプロジェクトは、技術があり経験のあるプログラマが、 コミュニティのより経験の少ないメンバーの書いたコードを検証する、という実力主義シス テムを採用している。Open Access jounals も通常は、どの記事を採用し出版するかについて 人のレビューを用いている。Box 3.2で述べた様に、MERLOTのようなリポジトリは、OER に対して同様の機会を提供している。人の手によるレビューというプロセスは、学術領域で は品質の保証のために最も用いられる方法の一つである。この方法が有名になり良く理解さ れていることと同様に、リポジトリ内の資料の品質を保証するためにレビューを使う体系に 対して他の議論もなされている。Taylor(2002)は、このプロセスは普及方法と同様に、学習リ ソースのクリエイターに対して理解と報酬を与えることで、教育者への報酬システムの不備 を受け入れることにも使うことができると述べている。さらに、レビューの決定をより信頼 できるものにする必要があるが、そのためには統一した基準におけるオープンなレビューが より適していると Taylor は述べている。しかし、既に述べたように、このシステムは高価か つ時間がかかる。加えて、レビューシステムは考えられているほど公平ではなく、研究に対 して保守的な面を持つとして時に批判される。この議論により、記事に対して誰もが公共の 場でコメントする可能性などの代替モデルに対しての議論が行われるようになった。Nature は、Open-peer-review を2006 年の 6 月から 9 月まで 4 ヶ月の間試行した。しかし、このシス テムは以下の結論により却下された :

この試行にはかなりの関心があったにもかかわらず、かなり小さな割合の著者し か参加しようとしなかった。Open Peer Reviewに対しては、原稿を公開投稿しシ ステムの試行後に反応した著者達の間では、編集者の視点と比べると非常に大き な興味が述べられていた。このシステムに参加した著者のうち半数ほどはコメン トを受け取ったが、例によって web のトラフィックと比較するとそれは非常に少 
なかった。多くのコメントは技術的に現実的なものではなかった。このフィード バックは、研究者たちの間ではコメントをすることが明らかに気が進まないとい う傾向を示している。(Nature2006)

OCW initiatives のような公共機関をもととしたプロバイダや、イギリスの Open Learn、才 ランダの OpenER のような大学のオープンプロジェクトで使われているほかの品質管理アプ ローチでは、機関のブランドや評判を用いることで、web サイトの教材は良い品質にあるこ とをユーザに納得させている。そうでなければ、その機関の名声はリスクにさらさる。この ような機関では、コースの公開前には国際的な品質チェックを行うことが最も一般的である が、これらのプロセスは資料の使用者がそのプロセスを追うことができるという点でオープ ンではない。

3 番目のアプローチは、中心的に管理するようデザインされたプロセスを持つものではな く、むしろ個人ユーザに、ユーザの望む全ての領域で学習リソースが高品質で、使いやすく、 良いものであるかを決めてもらうという方法である。これは、ユーザがリソースに対して評 点を付け、どのようにそのリソースを使用したかを記述することが出来るようにしたり、web サイト上でダウンロード数を表示したりすることで可能となる。これはインターネットベー スのショッピングサイトや音楽サイト等でよく使われる、低レベルの、またはボトムアップ のアプローチである。このようなアプローチに対しては、品質というものは学習リソースが もともと持っているものではなく、コンテキストに依存するものである、という議論がある。 あるリソースが有効かどうかを定めることができるのは、まさに特定の学習環境だけであり、 それゆえにユーザこそが判断するべきである。このようなアプローチを採用した例として Connextions がある。彼らは、編集プロセスを、出版後レビューのために第三者レビューアー に公開した。ユーザは、全てのコンテンツ(どのような品質のものも含む)にアクセスするこ とができ、また教材をレビューする能力を持つ。Connexions によると、同じコンテンツが、 それぞれ異なる視点を持つたくさんのユーザによりレビューされる可能性がある、という点 がこのアプローチの強みである。教材は、様々な"レンズ"を通して閲覧することができる。 例えば、Professional societies, universities, school boards, publishers, consumer unions という分類 や、colleagues, peers という分類、most popular content, most linked, highest user ratings という分 類、 learning assessment rating という分類などがある。

まとめると、品質管理に関してはいくつかの異なるアプローチ方法が存在しているという ことである。図 7.1 のように、この方法は中心管理的なプロセスでもそうでない方法でも可 能であり、またオープンなプロセスでもより閉鎖的なものでも使用可能である。また、これ らの方法を様々に組み合わせて利用することも可能である。 


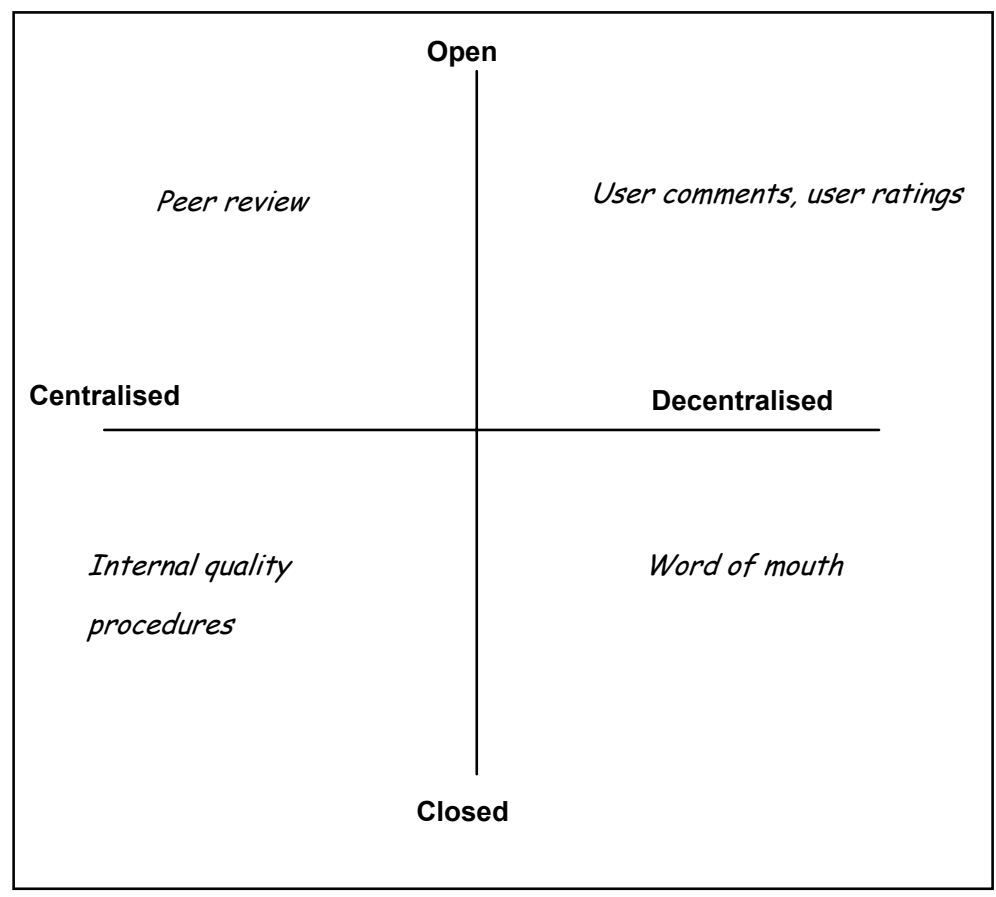

図 7.1 質管理プロセス

\section{2 コンテンツの翻訳とローカライゼーション}

UNESCO 国際教育企画研究所(IIEP)によって編集された OER 関するオンラインディスカ ッションのレポートでは、OER は"教育的であると同時に文化的であり、その点で OER は 教育、学習において文化的に特有な手法、アプローチへの洞察をユーザ行わせる"と結論付 けている(Albright, 2005)。大多数の OER は英語で記述されており、西洋文化に基づくことに なりがちである。これにより、非英語圈、非西欧圈の環境においては教材の信頼性が制限さ れている。言語の障壁と文化の違いにより、OERにおいて発展途上国を知識を拡大する貢献 者になるよりも知識の消費者にしてしまう危険性がある。また、発展途上国の機関が外部の 既存のコンテンツに依存するようになり、新しい、その地域の OER を作り出しコンテンツを 提供する側にならなくなるかもしれないという問題も提起されている。

さらには、OER が作られ、複数の言語が用いられ、教育の方法論が確立されている環境で は、彼ら開発者の文化や教育規範に基づく特有の物が作り出される。これらは、他の文化の 理解の妨げとなり、(1)機能不全な教育につながり、(2)発展途上国の研究、訓練、経験、理解 の可能性を減らしてしまう。翻訳は、この二つの問題に対する少なくとも部分的な解決とな る。部分的というのは、すなわち OER の本当の価值が理解されれば、各地域のコンテンツを 理解する必要性と方法のためには、多言語へ対応できる本当の能力 - 単なる翻訳よりも を持つことが必要となる。OERの地域化は言語だけでなく文化にも関わる問題なのである。 
Albright によると、Universia(スペイン語とポルトガル語圈の国々のための高等教育ポータ ルを管理しているコンソーシアム)と China Open Resources for Education(CORE)は共に、それ ぞれの地域で品質の高いコンテンツを利用できるようにするため、MIT OCW 教材を翻訳す る動きを始めた。両組織は、文化的自覚や応答、地域のコンテンツの生成に取り組んできた。 Universia はその活動を、翻訳から、OCW オフィスの設立資金を提供することでメンバーの 大学を支援し、独自の OER を出版させることへと移している。(Pedró, 2006c) CORE は、教 材の翻訳の支援を続けている一方で、中国での OER の動きを促進し中国のコンテンツを世界 へと広げる動きを行っている。主な課題は、発展途上の世界に、教育のデザイン能力を養成 することである。この能力の欠如が続く限りは、一握りの国際的な「ブランド」がおそらく は市場を支配し続けるであろう。教育デザイナーを支援することで、著者が OERにおいてよ り活動的となり、コンテンツを特定個人、組織の要求に対して適応させることができるよう になる。

オリジナルの文脈と、教材を新しく用いる際の意図との文化的、教育的な違いを発見する ことは重要である。その国に住んでいるネイティブスピーカーな翻訳者でさえ、未知の聴衆 に対して文脈(context)を提供することは困難だと感じることがあり、それが品質管理の問題 につながる。加えて、翻訳者は必ずしも教育者ではないため、新しいコンテンツを作る際に 効果的に貢献するために必要な教育的な背景を持ち合わせていないこともある。解決法とし ては、地域の大学と機関が協力を深め、OER サービスコミュニティにボランティアの翻訳者 を採用し、世界の異なる地域間での知識共有をサポートする多言語プラットフォームを作り 出すことが考えられる。また、European Schoolnet のCAIBRATE プロジェクトにおいて、他 のアプローチも研究されている。このプロジェクトの目的のひとつに、翻訳が不必要でロー カライゼーションの必要性を最小化するような方法で学習リソースを作ることができるかど らかテストすることがある。多くのアニメーションやイラストを使用した資料は、おそらく は資料中のテキストを取り除くことのできる可能性を持ち、少なくとも似通った文化的様相 を持つ国々の間では"自由に飛び回る"ことができるかもしれない。

OER の条項とその利用の間にある厄介な不均衡は、外部とのつながりが薄かったり、イン フラが未発達であったり、資金調達に制限があったり、原産の資源に限りがあったり、技術 的に未発達であったり、教育やサポートが不足しているような低所得国に対するほかの障壁 によって、さらに悪化させられている。一方でオンラインでの議論では、「何もないよりは 何かあるほうが望ましく、発達途中である OER は非常に価值のある資源である」とのように 認識されている。アフリカの豊富な複合文化、複数言語の学習リソースは組織構造やリソー スを OER てと変換させることを待ち望んでいる。アフリカや南アメリカ、アジアにおいて、 そしてそれらを代表して、新しく独自の OER を発展させる必要があることは言うまでもない。 これら全ての地域では、文化的に敏感で、教育的、地域的に適切で、技術的に便利で利用し やすい資料を作成するため、重要な努力が進行中である。こういった状況では、非常に柔軟 で資料の発行に時間のかかるフォーマットと、多くの資料を発行するための柔軟でないフォ ーマットを使用することのトレードオフを考えると、6 章での議論は重要である。 
現地スタッフを育成し、教育するための能力を開発するためのパートナーシップの例とし て、22 の小さな州における OER の発達を促進するための試みがある。("小さな州"とは、人 口が 400 万人以下の州であると定義した。）この試みでは、小さな州のバーチャル大学は、 オンライン、遠隔学習の能力を発達させるために限られた資料、技術しか持たない州とネッ トワークを作成することを許すように設計された。OER は目標 - ライフスキルやビジネス や管理、教育におけるプロフェッショナルの発達などを含む - を共通に持つ領域では発達す るであろう。The Development Gateway Foudation の OER ポータルは、教育へのアクセスと" 発展途上国の人々がより良い生活を送ることの助け"となるためのアクセスを均等化するた めの、もうひとつの試みである。

\section{Box 7.2 The African Virtual University}

今日では教育、訓練において最も見込みのある発達のうちのひとつとして OER の概念は認められてお り、アフリカバーチャル大学(AVU)はアフリカの OER の設立、組織、普及、利用のために協力的、強調 的)な体系を発達させた。AVUの試みは、知識と教育は一般的には良いもので、所有されておらず、OER は人間の知識と創作性と富に極めて大きく貢献するであろうものであり、共有することで限られた資源 を無駄に複製することを避けることができるという信念に基づいている。AVU はアフリカの学習者、 教師、研究者の ニーズを集中させるための概念的な骨組みと構造を発達させてきた。

AVUの中では、Development Gateway OERトピックページ、MIT OCW教材、WiderNet - eGranaryの試み、 Commonwalth of Learning STAMP 教材、TESSAプログラムの教材、AVUデジタルライブラリなど、多く のOERの試みが既に存在している。その構造物のひとつの目的は、全ての試みをひとつの体系の下に結 合することである。

オープンコンテンツの促進のため、アフリカの大学により、AVU はギャップ(GAP)の分析に始まる $4 つ$ の突出したコンセプトを打ち出した。

1. 関連した団体(governing bodies)からサポートが少ないことで、既に参加が少ないのをさらに悪化さ せる。

2. 明確な品質保証メカニズムがないことで、OER の曖昧なスタンダード(無料ならばつまらないもの に違いない)に結びついている。

3. オープンコンテンツが"無用の長物"である潜在性があるため、それにより大きな初期コストが熱意 を削ぐ

4. 曖昧な知的所有権のポリシーが教育者の参加の妨げになっている。

試験プロジェクトでは、各地のミラーサイトは（supported by workshop at each of the sites）MITから得た オープンコースウェア教材を用いていた。試験プロジェクトはオープンライセンスの概念への強い支持 につながったが、いくつかのプロジェクトでは、教育者と学習者がMITのオープンコースウェアにアク セス、利用しなくなったことがわかった。そういったところでは、OERに対する理解が一般的に欠けて いたり、コンピュータや許容できる速度でのインターネット接続などの技術的資源が欠けていたり、コ ンピュータに対する教養が欠け、教育が必要であったりする。（続く） 


\section{Box 7.2 （続き） The African Virtual University}

システムのアーキテクチャは、国際的な OER の活動と、プロセスの確立・デザインのシステムと枠組み・ 開発・アフリカ大陸における OER の運営と共有における AVU 自身の経験に関する既存の理論と見解に対す る分析の下に成り立っている。このアーキテクチャは、4 部分から成る。

1. 創作 : "一から"、OER ; "ユーザとプロデューサー"の構造化されたコミュニティ; 相互運用性と承諾 (compliance) ; OER を作り出すための反復するプロセス ; OER のローカライゼーションと文脈付けを 作り出す能力

2. 組織化：管理、運営スキーマ; 保存、ポータル化の仕組み ; タグ付けやメタデータのシステム ; リポ ジトリの開発 ; 組織(institutional)の発達 ; 文化を共有するための知識化

3. 普及 : 鋭敏化(sensitisation)(文化的事柄に気づき、反応すること); OERへのリモート、ローカルアクセ スのための配信方法 ; パッケージ化とマーケティング ; 配信のスケーラビリティ ; 分散化と中央化の 選択、または共用

4. 利用: OER のリポジトリにアクセスし、アップデートするための仕組み; コンテンツの利用、再利用 ; コンテンツの再編集(re-authoring)と目的の変更(re-purposing)；品質保障の仕組み；教材の認定 ; 持続性 とビジネスモデル化

このアーキテクチャはいくつかの組織で議論されてきており、実装途中である。

開発、実装にはモジュールアプローチが採用され、2008 年の 9 月に終了する予定である。

Source: Bateman (2006) and www.avu.org

\section{3 障害者のためのウェブアクセス}

多くの OER プロジェクトは、デジタルの学習リソースに対するアクセス増加を目的として おり、そのため様々な障害を持つ人々のことを考慮する必要がある。インターネットは、情 報や相互作用に対寸る前例のないアクセス方法を提供しているが、多くのウェブサイトやウ ェブソフトウェアは未だアクセスバリアがあり、そのことにより何百万もの障害者がインタ 一ネットを利用寸ることが困難、不可能になっている。しかし、印刷、聴覚、視覚メディア におけるアクセスバリアは取り除くことが可能である。WWW コンソーシアムの一部分であ る Web Accesibility Initiative は、障害の違いがじのようにインターネットの利用に影響するか、 やこれらの障害を乗り越えるには何ができるのか、を調查している。より利用し易いウェブ サイトやウェブのソフトウェアが利用できるようになれば、障害者たちはより効率的に、イ ンターネットを利用し貢献することができる。

ウェブのアクセシビリティにおける原理は、異なるユーザの要求、好み、状況を満足でき るように、柔軟にウェブサイトやウェブソフトを設計することである。これはまた、低速な インターネット回線を利用していたり、腕を怪我して「一時的に障害者」であったり、年を とることにより能力が変わってしまったり、など、特定の状況では健常者に対しても利益と なる。Web Access Initiatives の役割のひとつは、OER Initiativeにとって非常に有用となりう 
る、インターネットソフトウェアや開発者においてのアクセシビリティの解決策を示したガ イドラインや技術を開発することである。異なる障害を持つ人々の、デザイン要求には以下 のようなものがある。

- 視覚: 説明つきの画像や映像、十分にマークアップされた表やフレーム、 キーボード支援や画面読み上げの互換性

・ 聴覚: 音声に対するキャプション、補足イラスト

・ 身体(physical)、スピーチ: キーボードや単一スイッチのサポート、音声 ポータルにおける発話入力の代替手段

・ 認識、神経: 言語レベルに応じて一定したナビゲーション、イラスト、 摇らめきやストロボのないデザイン

アクセスの容易なウェブデザインは、他のユーザに対しても良いデザインにつながる。Web Accessibility Initiative により提供されたイラストは、複数様式(視覚、聴覚、触覚のサポート) に対応しており、これは小さな画面の携帯電話やWeb テレビなどの利用者に利益をもたらす。 また、低帯域(画像のダウンロードに時間がかかる)や、うるさい環境(音楽を聴くことが困難)、 画面のグレア(画面を見ることが困難)、運転中(目、手が忙しい)等の状況でウェブサイトのユ ーザビリティを向上させる。他にも、アクセスの容易なウェブデザインの例としては、異な る学習方法や低い教育レベル、第 2 言語におけるアクセス等の支援となりうるような、圥長 な文章、音声、映像などが挙げられる。さらには、スタイルシートを用いることでより効率 的にページを変更し管理維持寸ることができる。音楽ファイルにキャプションを付けること は、コンテンツに対する高速なインデキシングや、高速なコンテンツの検索につながる。

\section{4 アクセシビリティに関する技術的事項}

オープンソースソフトウェア(OSS)

OER の活動がオープンソースソフトウェア (OSS)を促進する理由は、公開性(openness)の定 義とそもそもの考え方に由来する。しかしオープンソースソフトウェアは、OER と綿密な関 係を持っている一方で、他の理由により高等教育においても押し進められている。今日では オープンソースソフトウェアは一般的に使用されるようになっているが、多くの一般ユーザ にとってはそれほど馴染みのないものである。なぜなら、オープンソースソフトウェアはま だ、OS やワープロや表計算のようなオフィスアプリケーションのような形でパーソナルコ ンピュータ上で用いられてはいないからである。そうであっても、多くのユーザはインター ネットを閲覧する際(Apache)やメールを使用する際(Sendmail)に日常的にオープンソースな ソフトウェアやデータフォーマットを使用している可能性がある、ということに気づいてい ない。現在では、IBM やヒューレットパッカード、サンマイクロシステムズ、ノベル、Computer Associates などの主要な IT 企業は、オープンソースソフトウェアを自身の主要戦略の中に組 み込んでいる。数千のコンピュータから回答を得た Google の調査では、オープンソースソフ トウェア(Linux)で動いているもの全てと Yahoo!はオープンソースソフトウェアを住所録と いう主要ビジネスに用いている。European Commission により行われた調査では、ウェブサー 
ビス、サーバの OS、デスクトップの OS、ウェブブラウザ、データベース、メール、その他 の IT インフラシステムを含むいくつかの市場では、オープンソースソフトウェアのアプリケ ーションが上位 3 段を占めていると報告している(UNU-MERIT, 2006)。オープンソフトウェ アを広く定義すれば、オープンソースソフトウェアに関連したサービスは、2010までには IT サービスで 32\%を占めるまでに至り、経済においては同年までにヨーロッパの GDP の 4\%を 占めるまでに達する可能性がある。

オーストラリア、ニュージーランド、イギリスにおける高等教育機関での比較調查では、 「オープンソースソフトウェアは調査に応じた全ての第三教育機関によって既に使用されて おり、主な理由は所有コストの低さとソフトウェアベンダーへの依存がないことである」と 報告した。(Glance, Kerr and Reid, 2004)The British OSS Watch(2006)では、「高等教育機関、生 涯教育機関の両方において、オープンソースソフトウェアを積極的に利用している傾向が見 られた」と報告している。また、「オープンソースソフトウェアについてそれぞれのポリシ ーで言及している機関は25\%しかないが、実際には 77\%の機関がソフトウェアを調達する際 にオープンソースソフトウェアの利用を視野に入れている」と言われている。アメリカでの 調査では、アメリカの高等教育機関の 57\%が何らかの形でオープンソースのインフラソフト ウェア (OS やデータベースを含む)を利用していると示している(Abel, 2006)。3 分の 1 の機関 がオープンソースソフトウェア(コースマネージメントシステムやポータルを含む)を使用し ている一方で、完全にオープンソースソフトウェアを使わないと決めている機関はほとんど ない。またほぼ同様の割合の機関がオープンソースソフトウェアに対して「深刻に議論」し ている。Abel は、高等教育機関は商用ソフトウェアの代わりとなるものを探しており、また 商用ソフトウェアが彼ら「独自のニーズ」を満たすことができるのか、という点に関心を抱 いている、と結論づけている。 OECD(2006)は、高等教育の分野で商用ソフトウェアベンダー が大きな市場シェアを得ているとしても、社内(in-house)ソフトウェアの開発やオープンソー スソフトウェアの使用は注目すべき傾向であると報告していた。社内(in-house)オープンソー スソフトウェアの魅力は、プラットフォームの機能がよりカスタマイズ可能な方向へと動い ているにも関わらず、認知機能が不十分であったり商用製品に対する教育上の制限にある。

何がオープンソースソフトウェアをこれほじ魅力的にしているのだろうか?なぜソフトウ ェア開発のプロではない人々や機関がオープンソースに注目するのだろうか?オープンソー スソフトゥェアのいくつかの利点について述べているレポートが増えてきている。Eruopean Commission によって開催されたシンポジウム(2001)では、ヨーロッパでは一般的な分野にお いてオープンソースソフトウェアの使用経験は増えており、その適応的な機能性、トータル コストの低さ、ベンダーからの独立性とオープン性の順守、相互運用性、セキュリティなど の理由によってオープンソースソフトウェアは使用されているとの結論に至った。UNESCO 国際教育企画研究所(IIEP)はオープンソースソフトウェアの利点を以下のように挙げている。 
1. 選択肢の増加と競争

2. オープンソースと他のオープン標準なものとの提携性

3. 公益として位置付けられたソフトウェア

4. 技術的な自己信頼性の増加

5. ベンダーを固定する必要の減少

6. 透過性

7. セキュリティリスクの最小化

もちろん、オープンソースソフトウェアが他の商用ソフトウェアに比較して優れていると いう考えに対しては疑問が残る。オープンソースの理論的根拠は、十分に証明されたり、研 究されたことはほとんどないと言われてきた(Tuomi, 2005)。これにより、商用ソフトウェア の開発者が、「ソフトウェアのインストールや操作、維持などの全体のコストを考えた時、 オープンソースソフトウェアが低コストだと言われていることは疑問が残る」と反論する余 地がある。この議論においてはどの場合でも、ライセンスのコストは全体のうちの小さな一 部分である。さらには、大学などの大きな組織では、オープンソースソフトウェアを実装し 支援、維持していく試みは非常に問題となりうることもしばしば指摘される。American University の情報部門長は述べている。「デザインし開発することは面白く刺激的である。さ らには、開発プロセスの途中では、成功したと宣言し次に取り掛かることができる。メンテ ナンスとサポートは、魅力もなければ明確な終了もない。これらはそれほど面白くもなく、 そして永遠に続く」(Stunden, 2003)。彼女は、大学が自身のオープンソースソフトウェアの取 り組み(Initiative)が成功してほしいと望むのであれば、このメンテナンスとサポートのジレン マに対する創造的、協力的な解決策を早急に生み出す必要があると結論している。同様の視 点が OECDにより行われた研究で述べられている。そこでは、関連サービスが必要な際には、 非常に実績のあるアプリケーションの信用性と信頼性が商用ソフトウェアを使用する理由で あると述べられている。高等教育におけるテクノロジーの役割の観察者の一人が、オープン ソースソフトウェアの考え方を「肯定的両価性(affirmative abivalence)」と呼んでいる。情報 部局長は、オープンソースソフトウェアは将来の一部分になると確信しているが、現在はま だ様子見の状態を取っていると述べている。

\section{相互運用性}

OER の概念は、他の誰かがどこかで作り出した物体を再利用し最目的化するという考えの もとに成り立っているため、相互運用性は重要な問題となる。ソフトウェアに関して言えば、 "相互運用性"という言葉は、異なるプログラムが共通の手順を通じてデータを交換し、同じ ファイルフォーマットを読み書きし同じプロトコルを使用することができる可能性のことを 表す。異なる時点、異なる開発者によって開発されたソフトウェアは、同時に操作できるべ きである。学習リソースはリポジトリを通じて検索できるべきであるし、ダウンロードされ、 それらを統合しプラットフォーム間で適応できなければならない。まだ多くの学習リソース 
は学習管理システム(LMS)の中に閉じ込められている。時折見かけるパスワードを必要とす るサイトは、外部の人間が資料を利用することを妨げているし、同様にプラットフォーム間 の相互運用性の欠如も妨げとなっている。典型的な例としては、増え続ける e-portfolio の利 用がある。e-portfolio では、学習者、教師、研究者がある機関から別の機関へと移動したり、 ポートフォリオを持ち歩き新しい環境で使用する際に問題を生じる可能性がある。

オープン標準は相互運用性を生み出す。標準(standard)は規格化であり、実践であり、また 2 以上のものの間で予測できる形式で相互作用できるようにインタフェースを定める際に用 いられるリファレンスモデルである(Walli,2005)。「オープン標準の最も良い例はインターネ ットそれ自体だ」とも言われている(CED, 2006)。スタンダードにはデ・ファクト・スタンダ ード (事実上の標準) とデ・ジューレ・スタンダード（法律上の標準）の 2 種類がある。デ・ ファクト・スタンダードは、典型的にはひとつのベンダーが市場を圧倒したり独占した結果 として現れる。デ・ジューレ・スタンダードは、組織や委員会により、スタンダードを選定 するという目的で、確立された手順により作り出されるものである。これらは公衆のもとで、 "全てを含んだ状態で"、合意に基づいて作り出され、誰もが自由に改変して使うことができ るという意味でオープンである。新しいスタンダードの制定は、経済援助の必要な専門的な タスクである。アメリカの Comittee for Economic Development(CED, 2006)は近年のレポートで 述べている。

「スタンダードの制定は、政府によって(もしくは、少なくとも一般の基金によって)支援 される必要がある。なぜなら、'スタンダードで金儲けをするものは誰もおらず、スタンダー ドのために皆が金儲けをする'。」このように続く：

オープン標準の主な利益は、それが相互運用性を促進し、コミュニケーションにお いて異なるデバイス、アプリケーション、ネットワークの利用を許すことである。 このような相互運用性は、ネットワーク効果の発達と Metcafe's law の運用において 非常に重要である。Metcalfe's law は、ネットワークの価值はユーザが増えていくに 従い大きくなることを示している。相互運用性はそれぞれのユーザの追加に対しそ の利益を完全に引き出すことを可能とする。この利益が莫大になるケースも存在す る。The Nationa Institute of Standards and Technology は、情報システムにおける相互 運用性の欠如は建設業界において毎年 150 億 US ドル以上の費用につながり、自動 車や電気産業の供給チェーンにおける相互運用性の欠如は年間でさらにトータル で 89 億 US ドルの費用につながる。

オープンスタンダードの欠如により更なる費用のかかる例は他にも、オーストラリアでの OECD のケーススタディのひとつから見ることができる。そこでは、学習管理システム(LMS) のスタンダードが真に欠如しており、教育機関により作られた多くの資料が他のシステムに 容易にエクスポート、インポートできないであろう状態であった。これは、オーストラリア や他の地域では、共有の意識が少ないからのみならず、既にあるシステムの外で教材を得る ことが困難であり費用がかかるという理由で、多くのコンテンツが閉じ込められていること を意味する（Suzor, 2006）。この異なる著者によって開発された学習リソースは決して同じ 大きさ、外観と䨌囲気を持たず、同じ環境では作成されないという問題には解決策がある。 The Sharable Content Object Reference Model(SCORM)は、ウェブベースの e-Learning における 
標準と規格の集合であり、クライアント側のコンテンツとホストや LMS との相互運用性、 アクセシビリティ、ウェブベースの学習コンテンツの再利用を可能とする通信方法を定めて いる。SCORM モデルは、資料に対する一般的な情報（タイトルや言語、キーワード） と ライフサイクル情報、メタデータに関する情報、技術情報、教育情報、資料の教育的特徴、 著作権に関する情報などから成る。しかし、ここでも、SCORM のメタデータを学習リソー スに付加することは能力と時間と資源を必要とするであろう。

\section{OER の動きに影響を与える支術の出現}

Introduction で述べたように、デジタルコンテンツの作成はだんだんと容易になってきてい る。ソフトウェアツールは、よりユーザフレンドリーに成ってきており、現在ではウェブサ イト、ブログやWiki を、フリーで供されていることもあるオンラインツールを使って、数分 で作ることができる。そしてWiley(2006)に指摘されているように、OER の活動に参加する こともますます簡単になってきている。以下のような技術的進展がこのような発達を支えて いる。:

・ オープンなリソースを簡単に管理できるインフラストラクチャーやソフト ウェア(アメリカ、オーストラリア、ニュージーランド、日本、中国の eduCommons)

・ OER のリポジトリを簡単につなぎ連合させることのできるインフラストラ クチャー(European Scoolnet LIMBS open source brokerage system)

・資料を簡単に作り出すことができること。なぜなら、ポッドキャストやス クリーンキャスト、ビデオ配信やブログ、Wiki を利用する可能性があるか らである。

・ ビデオ iPod に代表される、ストレージの容易さ - 一科目分の教材 (academic program of materials)を全て保存することのできる小さなデバイス

・ ブロードバンド接続がなくても、資料を使うことができるようになる、リ ポジトリのミラーリングの簡単さ(eGranary は発展途上国に 40 ほどのパー トナーを持っている)

・配布の容易さ(RSS や ATOM などの技術はメタデータの配布と再利用を一 般的にした)

- 資料の集合(assembly)、文脈付け、集合体(aggregation)を簡易化するソフトウ エアによる資料の再利用の容易さ。 
近い将来の高等教育における技術の与える影響を考えてみると、年鑑 Horizon Report(2006) は、既に学生たちが所有しているような、携帯電話や MP3 プレイヤーなどの個人端末を教育 コンテンツの配信に用いることが流行となると述べている。また、学生たちはより個人向け のサービスや、メディア、知識情報、学習に対するオープンアクセスを望むようになってい ると言われている。Alexander(2006)は、発展中の技術の傾向とその高等教育への影響を書き 表した時に同様の予想をしており、また Hilton(2006)も同様である。レコードがあまり売れず、 レコードから分割された楽曲に人気が集まっている音楽業界と同様に、コンテンツを切り離 し、教育用提供物の個人化がより頻繁に行われる事が望まれている。これら両方の傾向 - サ ービスの個人化とコンテンツの分離化 - は、今日の決まったカリキュラムが多いグループに 適用され、前もって決められたペースで行われる高等教育に対しての挑戦となる。

教育コミュニティにおいて興味深い他の特徵として、協調フィルタリング、フィルタリン グ技術を用いて「最も面白い」資料を探しだす技術の促進があるが、それ以外にも継続して 行われる会話や、社会ネットワーク内での資料の推薦と相互リンク；RSS フィードに基づい たサービスなどがある。RSS は絶えずアップデートされ、エンドユーザに対する情報とリン クを持ち、テーマごとに関連性を持たせたコンテンツが利用可能な個人ライブラリである(ポ ッドキャスト、ビデオキャストが可能である(OLCOS,2007)。既に、ブログや Wiki, ソーシャ ルブックマーク、ソーシャルタギング、実時間インタラクションを用いた協調オーサリング プラットフォームなどのソーシャルソフトウェアがますます利用されていることを述べた。 これらのツールは、平均的なユーザが利用を開始する際の敷居を下げている。なぜなら、ペ ージを投稿する必要がなく、小さな投稿、音声メッセージ、写真(文章でなくても良い)を投 稿するだけで参加することができるからである。情報の小さなかけらから、協調的、時には オープンな方法で大きな物体が作られる。こういった傾向は Web2.0 の一部分である。Web2.0 は、部分的に新しいアプリケーションと新しいユーザの習慣、属性の発現であり、インター ネットが"情報が送信され、費やされる「媒体」から、コンテンツが作り出され、共有され、 修正され、最目的化され、伝えられる「プラットフォーム」"へと変化したと表現されること もある(Downes, 2005)。またこの発達は e-Learning のアプリケーションがネットワークのよう に見え、振舞いだしたことを示している。ここでは、コンテンツがよりオープンで協調的な 方法で - 機関というよりも学習者たちの間で - 作り出され、使われ、配信されている。

この傾向は、個人的な学習環境の出現にも支えられている。e-portfolio は今まで数年は学 生が自身の活動の結果を保存し、表現し、時おり議論するための手段として存在してきた。 この発達はオープンソースプロジェクトELGGによって牽引されてきた。これは個人発行や ソーシャルネットワーキングに基づくオンラインの個人学習スペースを作り出していた。

ELGG は、個人学習環境 - 近年高等教育においてより一般的になっている必要な補充物や競 争相手に対する LMS - と呼ばれるものの初期のバージョンである。LMS や同様のアプリケ ーションを通じて、機関はコース管理やコースの提供、デジタル資料を取り扱っている。個 人学習環境は、コースそのものよりも学習者に注目し、伝統的な LMS に比べて学習者によ り多くの主体性を与え、(高等教育と同様に)特に個別、自主的な学習スタイルに適している。 このような発達は、機関から学習者へと力が移動しており、学生や学習者が学習を自ら管理 するという状況を示している。増え続ける OER に対する学習者の簡単なアクセスがこの傾向 を強めていると推測される。O'Hear(2006)が書いているように、伝統的なアプローチによる 
と e-Learning はコースや時間割、テストに基づいて構成される傾向にある。これらは、機関 のニーズというよりは個人学習者により動かされてきたアプローチであった。これと対照的 に、e-Learning 2.0 は、"小さなかけらを、大まかにつなぎ合わせる"アプローチで、別々の、 しかし相補的なツールやウェブサービス - ブログや Wiki、他のソーシャルソフトウェア をつなぎ合わせ、アドホックな学習コミュニティを作り上げることを支援している。

\section{データの蓄積と長期間の保存 - 倫理とリスク}

ますます多くの教育者が、前節のようにソーシャルソフトウェア等を利用することで新し い学習方法を生み出している。無料で利用できる、協調的なコンテンツのドローイング、執 筆、ホスティング(hosting)の為の商用ソーシャルソフトウェアやウェブサイトは教育におい てますます利用されるようになっている。主な理由は、学生たちが既に他の再生産的な活動 でこれらのツールを利用しており、利用を推し進めるからである。多くの教師もまた、この ようなツールを自身の IT インフラの中で提供できる大学はほとんどない一方で、これらのツ ールは無料であるという理由でその使用に利点を見出している。しかし、これらのツールの 利用には、セキュリティの問題に加え、道徳的、法的な問題がある。

進行中の仕事に用いるホストとして、もしくは長期間のストレージとして無料商用サービ スを利用することは、費用回収モデルの変化や第三者による会社の買収、破産などの際に、 データに対するユーザの管理が非常に小さくなるにつれて大惨事につながりうる。現在と同 様の条件下でどれほどの期間無料でサービスを利用することができるか、変化が起こった時 に保存しているデータをユーザは利用できるか、にはまったく保証はない。アメリカの National Academy of Science は、これをデジタルジレンマと呼んでいる。「デジタルな情報製 品を作り出し、修正し、完璧かつ無限に複製し、世界中の何百万の人たちにほとんど 0 のコ ストで配布することができる一方で、これらの製品は、少なくとも一時的に閉じ込められ、 アクセスできなくなり、完全に管制されたりする」（CED, 2006）。子供たちがソーシャルネ ットワークサイトを利用する際の個人セキュリティの問題はよく知られている。宗教や性別、 民族的な背景に基づくいじめや八ラスメントの問題は、高等教育の生徒の間でも同様に発生 する可能性がある。学生個人が不法なコンテンツ(子供のポルノや人種差別的なコンテンツ、 著作権を侵害している物)を作成、保存する場合には、大学のサーバでなく、商用のサービス プロバイダ上でも、道徳的問題と、おそらく法的な問題が生じる。一般的な授業の間にツー ルやサービスを用いた際ではなく、機関のコントロールの外でウェブサイトやソフトウェア を利用して先ほどの問題が生じた場合には、個人の教員と機関の責任は不透明になる可能性 がある。この種の出来事は、ここでは簡単に述べただけだが、来る OECD の New Millennium Learner というプロジェクトではより綿密に調査されるであろう。他にも、教育機関と、大学 の授業における活動で作成され、商用に利用できる可能性のあるデータの利用に興味のある 利害関係者との間で、道徳の衝突の問題という可能性がある。

データの保存とストレージに関する長期間論じられてきた問題は、個々の企業がなくなっ てしまうというリスクから大きくそれる。学問は、過去の累積的な記録と、現在の良く考え られた、オーセンティックで、すぐにアクセスできるデータに基づいている。デジタル情報 を保護するインフラを整備する努力はほとんどの国で現在行われているが、それは膨大な研 究データを生み出す責任のある研究機関がそのデータに長期間アクセスできることに責任を 
持つということを仮定しているからである。しかし、現在の技術の発展速度を考えると、今 から 10 年、50 年、 100 年後に個人データを求める将来の研究者や学生たちに手段を講じるこ とのできる機関はほとんどないように見える。JISC はこのように述べている:

紙ベースの素材は、直接の介入なしに、数世紀、そして 1000 年間生き延びること ができるであろう。これと対照的に、デジタルの物体は、10 年間生き延びるのに さえも活発な管理と保存が必要となるだろう(JISC,2006)。

価值があり長い期間には失われる可能性のある資料を、持続可能で合法的な方法で保存し ておく必要を認識している利害関係者は増えてきているが、これらの問題に対処する方針を 確立している国はそれほど多くはない。教育機関にとっては、これらは研究データや個人の 管理記録(テストや証明書など)、学習教材などの保存に関連する。技術的な問題と同様に、 政策と経済上の問題 - 権利と制限、保存を支援するための経済モデル、何が収集し保存する に值するほど重要であるかを決める透明度の欠如が挙げられる。おそらく必要なのは、同様 の基準、メタデータ及び安全な転送と保管を可能とする他の技術的プロトコルを利用して実 際の保管が配分されるような分散保管用のプラットフォームであろう。 


\section{第八章}

\section{結論、政策的意味合い及び提言}

本章では、OER ムーブメントとその発展を促進するために必要な政策アクションの意味合い について述べる前に、この報告書のこれまでの各章で扱った主要な論題を簡潔に提示する。 これらの論題は、それぞれ最も論じや寸い国際、国家、中間、または機関レベルによって分 けられている。 


\section{結 論}

提唱されてからまだ数年ではあるが、オープンエデュケーショナルソース（OER）の概念 に対する興味・関心は次第に高まっている。確かな統計データがあるわけではないが、プロ ジェクトの数、関係者の数、利用可能な資料の数のいずれもが拡大している。現時点では資 料の大部分が先進国で生産されているとはいえ、これは全世界的な発展である。さらに、信 頼できる数字を挙げることはできないが、OER はまた、組織間の国際的な連携やピアツーピ ア型の共同作業をも促進しているとも言える。教育機関で行われるものは特にそうであるが、 OER 構想は、透明性を生み出し、拡大寸る品質管理や、個々の納税者や学習者に利益をもた らす競争を一般的にシミュレートできる。その上、OER 活動はトップダウン的にもボトムア ップ的にも拡大しているように思われる。例えば、組織レベルで新しいプロジェクトが開始 される一方、同時に、個々の教員や研究者も自発的に OER を生産・利用している。OERの 概念は、知識を共同で創造し共有することの学術的価值を強化している。しかし、もし以上 の一般的な記述が明白なものであるとすれば、それは OER ムーブメントに関する更なる研究

（個々のプロジェクトに対する評価、よりよい知識ベースを構築するための利用者に対する 統計など）の必要性を明確に実証するような、散在するデータや事例証拠に基づいて確立さ れるはずのものである。

誘因と障壁に関する議論では、政府がこのようなプロジェクトに出資して個々の教員や機 関による OERの利用・生産を誘起するべきかどうかという議論と同様に、多くの基本的な促 進因子と抑制因子が認められている。結論としては、機関が戦略や政策のマイナーチェンジ を行うだけでも、強い技術的圧力の結果より多くの利用者を集められたり、機関や個々人が 経済的利益と非経済的利益の双方を得る機会が生まれたり、といったようなプラスの効果が 得られるだろう。また、これは主要な機関が表明したのだが、急速な発展が実現されつつあ る状況で何も行動を起こさないというのは大きなリスクを伴うため、大学はすぐにも OER ムーブメントに参加し行動を開始すべきである、とも結論付けられる。個々の研究者や教育 者の展望では、授業教材を公開することでもたらされるプラスの効果が多数挙げられている。 しかし、著作権に伴い制約が生じることや、多くの機関において OER の使用・発展の促進に 対する報酬制度が久如していることなどが、未だ重大な抑制因子として残っている。

デジタル資料の公開・利用に関連する著作権問題の調查では、既存の著作権体制は、OER ムーブメントの早期の成長に対して、また、教育における情報技術の普遍的使用の実現に対 して、おそらく最も深刻な障害となっている、とされている。いくつかの OER プロジェクト において、第三者のコンテンツに対する権利関係を明確化するために予算の半分が費やされ ているという事実が、この問題を例証している。調查の結果、研究者の大半は、彼らの承諾 がなければ商業的に利用されないということが保証されている限り、自身の成果を他者と共 有することに満足感を感じることが示唆されている。研究論文を公開的に発表している事例 の急速な増加がこの事実の明白な兆候である。いまだ多くの研究者、教員、機関が、著作権 問題について、必要とされるほど充分に知ってはいないようである。著作権に関する意識の 拡大と施策の明確化は、全ての高等教育機関にとって重要な協議事項である。 
OER 構想の数的な増大は、出資競争を活発化させると共に、収入を増やしコストをカバー するための他の手段（例えば、ロイヤルユーザコミュニティの設立、強いブランドの開発、 サイトのユーザビリティ強化、資料の品質改善等）を発見しなければならない状況を作り出 した。また、この数年で新しい原価回収モデルも浮かび上がってきた。技術の進歩は OER の生産・分配・使用を促進している。Creative Commons のような、より柔軟性のある新しい ライセンス供与の枠組みは、オープンコンテンツに関する新しい原価回収モデルとビジネス モデルを開拓することで、著作者や機関に、全てではないにしてもある程度の権利を予約す る機会を提供している。これらをひとまとめにして考えれば、構想が初期的な出資期間を超 えて存続する可能性が示唆される。さらに、理想的には、OER プロジェクトが全ての高等教 育機関に対し大衆が単純に期待するようなサービスとなり、また、個々の機関が、OER プロ ジェクトに携わる意志とそのための資料とを自身の中に見付けるだろうということが指摘さ れている。

OER ムーブメントの推進に関心を持っている者にとっては、構想の数を増加させる方法は 充分に考えられていない。既存の資料に対するアクセス性と利便性を拡大させようという二 ーズもまた存在する。アクセス性と利便性を改善させる方法として、いろいろな方法が導入 されている。一つは、様々な品質管理プロセスを使用したり、資料の検索を促進するメタデ ータを用いたりすることで、信頼性ある品質の高い資料を利用者がより容易に発見できるよ うにすることである。二つ目は、これまで資料へのアクセスが限定されていたりアクセスそ のものができなかったりしたグループ、例えば身体障害者や発展途上国の学習者からのアク セスを増加させることである。そして三つ目は、オープンソースソフトウェアの使用や、相 異なるプラットフォーム間での資料の相互運用性や再利用性を高める公開標準規格の使用と いった、技術的な手段である。アクセスを増加させる方法には、学習資料の現地語化（翻訳 だけではない）というニーズへの意識の改善や、ウェブサイトや学習資料をデザインする際 に Web Access Initiative ルールを適用することなども含まれる。

また、技術の向上、それが高等教育機関の持つ役割に与える影響、倫理的リスク、デジタル データの長期保存を再考する必要性なども OER ムーブメントの重要な課題である。

\section{政策的意味合い及び提言}

OER ムーブメントに関連する政策課題は、様々な角度から見ることができる。一つの見方 として、OER ムーブメントの拡大のから、個人・機関・国家に対するその意味合いを特定す ることが課題として挙げられる。別の見方としては、OER の生産・利用の更なる拡大を促進 するために、政策決定者に対して提言される活動に注意を向けることが課題として挙げられ る。最終的には、これらの課題は、管轄レベルに従って分割されるべきである。すなわち、 機関レベル、中間レベル（地域、州、省などのレベル）、国家レベル、国際レベルである。最 も主要な政策課題を特定し、それを適切な政策レベルに割り当てる際には、二つの異なるグ リッドが用いられる (付録 2 参照)。一つ目のグリッドは、一般的な政策課題を特定し、それ らを適切な政策レベルに割り当てる。二つ目のグリッドは、それぞれのケースにおける責任 の所在に依存して、様々なレベルで行われるべき活動をリストアップする。以下に記した、 課題と提言された活動とのリストは、このようなプロセスの結果である。 
OER に関連する課題のほとんどは国家レベル、中間レベル、機関レベルの管轄下にあるが、 理想的には、いくつかのトピックは国際レベルで処理されるべきである。相互運用性の課題、 例えば（World Intellectual Property Organization（WIPO）によって処理される）著作権に関す る立法行為の協調や (International Organisation for Standardization (ISO)、World Wide Web Consortium (W3C)、American National Standards Institute (ANSI)、 Internet Engineering Task Force （IETF）といった組織により行われる）標準規格の取り決めなどは、その効果を広範に与え るために、国際レベルで解決される必要がある。しかし、そのためには財政等のサポートが 必要となり、同時に、全レベルの出資体に対し、そのようなサポートを行うよう提言する必 要がある。

全世界的な、あるいは少なくとも国際的な視点が必要となるその他の課題としては、OER の生産・利用に関する音声ナレッジベースの開発が挙げられる。研究やWeb 統計の調整、そ の他のユーザ評価は、例えば OCW consortium による構想のように、国際レベルで行われる べきである。助成金を提供する団体には、それが政府機関であろうと私的財団であろうと、 評価活動のための出資要請に対して開かれたものであることを提言する。さらに、助成金を 受領する OER プロジェクトに対し、受領した助成金の一部を評価活動に回すよう要求するこ とを提言する。これに関し、Open University in UK における OpenLearn 構想はその良い例で あり、予算の $12 \%$ を研究と評価に充てている(Schuller, 2006)。

OER の促進や、あるいは、バーチャルユニバーシティにおけるオンライン討論、高等教育 におけるオープンソースソフトウェア、UNESCO International Institute for Educational Planning により組織化された OER などの意識向上活動は、世界中からの専門知識と経験の上に活用さ れるよう、国際レベルで行われるべきである。利用者の即時的利益への国際的協力の例とし ては、他にも、全 OCW コースに対するコンテンツ検索、GLOBE allianceにより展開された 同様の構想、4 大陸上のリポジトリに対する連合資料検索を可能とするために European Schoolnetにより開発された Learning Resource Exchange サービスなどがある。

\section{国家レベル}

OECD 地域などの一連の広範な国々に対し公布されている提言は、多くの難問に直面して いる。最も明白な・・・各国で高等教育の状況が異なっていることと関係している。また、 国家レベルや最終的な中間レベルの政府は、高等教育に関してさまざまな範囲の権威を有し ている。一部の国では、権威が領域を超えて拡大した結果、高等教育機関や政府に対し公的 な出資しか行われていない。他の国々では、機関はより独立的であり、私的な出資を受けて もいる。この点を考慮して、以下の一般的な提言を、国家レベル及び次節で扱う中間レベル の政府に対し公布する。 
OER はフォーマル学習とインフォーマル学習との境界をよりいっそう曖昧なものにする。 利用者統計によれば、OERの利用者の多くは自主学習者であり、また、資料の供給量の増大 に伴い、OER を用いたインフォーマル学習の成長も持続すると期待されている。国家政策の 観点から見ると、これは生涯学習をよりいっそう促進する機会であるとも言える。OECD 加 盟国において高齢者により実現されたチャレンジは、第 1 章で記述したように、より長い現 役労働とより多くの転職を必要とし、その結果、高等教育に対し、年配の学生や転職者の二 一ズに対応せよ、という新しい需要を投げかけている。これまでのところ、ほとんどの高等 教育システムは、このチャレンジに対応することに手間取っている。世界の国々には、第 4 章で記述したような、(高等教育への参加を広めるために行われる) OER プロジェクトを詳 細に検討し、フォーマル学習とインフォーマル学習・ノンフォーマル学習との間のギャップ を埋め、生涯学習を促進していくことを提言する。一から作成しなくとも少し修正すれば充 分であるような既存の資料やコンテンツを利用することは、増大寸る生涯学習のニーズを満 足する効率的な方法であると証明されるだろう。

OER は、多様な学習資料を供給することに対しても、多大な貢献が期待できる。豊富なデ ジタル学習資料は多様な学習方法を実現する。この点は、学習過程の個性化を促進するため の前提条件であり、多くの国々が採用している教育哲学でもある。国家的な視点から見れば、 多くの普通の考え方は、高等教育における OER に関する特定の政策を策定することではなく、 あらゆる種類のデジタル学習資料と教育システムのあらゆる部分に対する総体的な取り組み を行うことである可能性が高い(Johannesen, 2006)。このような OER 以外の政策は、商業用の デジタル学習資料やデジタル形式の国家的・文化的遺産も含んでいるだろう。国家政策上の 意味合いには、多量の学習用デジタル資料を確保しょうという意思が含まれている。

OER を含む一般のデジタル学習資料の生産・利用に対するナレッジベースの改善・構築が 必要であるように、OER に関する既存の著作権体制についてのレビューが必要であろう。教 育資料の公開利用と商業利用の間で中立的立場をとりたいと思う国は、多くの国々において、 今日の著作権体制は、デジタル技術に見合ったものではなく、時には商業関係者に対する偏 愛を呈することさえある、ということを意識すべきである。中立的立場をとるということは、 デジタル教材の教育的利用に対しょり寬大な見方をする方向へ向かって著作権立法のバラン スを修正する、ということであろう。各国がこの領域において新規に立法を行う際には、 Adelphi Charterにより提唱されたテストやルール（第 5 章参照）について考慮することを勧 告する。

OER の促進に積極的な国には、オープンアクセスムーブメントにより提唱された、「学術 研究の成果や国家的・文化的遺産は、公的な出資を受けることによりデジタル形式で入手で きるようにし、さらに、教育目的の場合にはフリーに利用できるようにすべきである」とい うアイデアについて考慮することを提言する。高等教育機関は、新規に知識を発展させる際 に、国家レベルまたは中間レベルの政府からしばしば巨額の出資を受けている。しかし、こ のような出資に際し、研究成果を一般社会と共有することが義務付けられることはめったに ない。この数年の間、「公的に出資された研究は、発表後すぐ公にアクセス可能な状態にする べきである」という主張と共に、オープンアクセスムーブメントに対する立場が数多く模索 されてきた(Suber, 2006)。世界最大の医学研究基金であるWellcome Trust（イギリス）など、 
一部の出資体では、受託者に対し公開発表に必要となる費用をカバーするための追加出資を 行う、という方針を採用している。用可能な基金のうちごく少量（例えば $0.5 \sim 1 \%$ ）を、機 関の内部で開発された学習教材を公開発表するための費用に割り当てる、というモデルであ る。これに加え、あるいは教育環境に適合するように、デジタル資料としての国家公文書や 博物館収蔵芸術品を “そのまま”で利用するか、あるいは教育環境で適切に利用するために 公開することは、教育部門において非常に重要なことであろう。これは、一部の国では国家 レベルで決定されることであり、その他の国では各機関レベルで決定されることであろう。 また、公文書や芸術品の中には、州あるいは地域レベルが管轄するものもあるだろう。

財政問題は、国家が OER に関し中立的立場をとりたいと思うか肯定的立場をとりたいと思 うかに依存し、さらに、基金が国家レベルの管轄に入るか否かにも依存するため、国家レベ ルにおいてもまた重要であろう。助成は、OER の生産・利用や新しい公開標準規格の開発、 既存の公開標準規格の改良、IT インフラへの投資などに関寸る研究開発に関係している。ま た、出資は、高等教育機関同士の提携を促進する手段としても考慮されるべきである。イギ リスの JISC は、技術発展により実現されたチャレンジに高等教育機関が適応することを支援 するために、資金や戦略的助言、サービス等を高等教育機関に提供することを目的とした政 府主導のプログラムの好例である。

公的あるいは私的な提携を促進することもまた、国家レベルや中間レベルにおいて検討さ れるべき課題である。世界の国々に対し、デジタル学習資料が開発される際に時々そうされ るように、非常に効率的である部門と、新しい領域に参入する際のリスクを共有し低減する 方法との両面から、ノウハウと資料を統合することを提言する。

既に言及したとおり、一部の国においては、OERへのアクセスの拡大が持つ重要な役割に 対して、国家レベルで取り組む必要があるだろう。世界の国々には、公的な出資の下で開発 されたウェブベース資料に対するWeb Access Initiative 原理の利用を助成するガイドラインや 政策を公布することを強く提言する。ノルウェーでは、全ての公的なウェブポータルが Web Access Initiative 原理に従うことを求められており、これが一つのモデルとなる。

教育実践と教育資料の公開を目的としたノルウェーの「Roadmap 2012」では、OLCOS プ ロジェクトにより教育政策決定者や出資者に対する多数の提言がなされている。その一つに、 （ほぼ）完全に公的な出資を受けて作成された学術資料や教育資料は、適切なオープンコン テンツライセンスの下でフリーにアクセス可能な状態にする、ということを要求することで、 OER の発展を助成する、というものがある。この目的を達成するために、政策決定者や出資 者は、良好なオープンアクセス環境を整備する作業、例えば、学術・教育出版社、学術団体、 教育協会などとの交渉に従事している。さらに具体的には、教育活動を目的としたコンテン ツの再利用を自由に許可することや、コンテンツを修正・統合・再目的化する際に制限を設 けないことを要求すべきである。このような再利用性を拡張するためには、「コンテンツを作 成・提供する際にはオープンコンテンツの標準規格と形式を採用するべきである」というこ とを強調するような規定を設けるべきである。

学術機関や教育機関で利用されることを前提にそれらの機関で開発されたソフトウェアベ 
ースのシステムやツールについても、事務局は、可能な限り、また妥当な限りにおいて、公 開標準規格を使用し、オープンソースソフトウェアライセンスを採用することを政策決定者 や出資者に要求した OLCOS の提言を支持する。公的な出資を受けて作成されたインターネ ットベースのアプリケーションやサービスに関しては、公開 API (Application Programming Interfaces）を利用できるようにし、サービスを再利用する権限を与えるべきである。

\section{中間レベル}

地方、州、地域といった中間レベルの権威は、おそらく、国家間で最も形態が異なってい る可能性の高いものである。一部の国では、このレベルそのものが存在しないか、または、 高等教育に関しては何らの権威も存在しない。その他の国では、このレベルで行われる政策 が最も重要である。

このレベルにおける課題のうち、国家レベルの項で言及していないものとしては、著作権 に関するガイドラインの作成や政策の決定や、公開標準規格の調整作業などが挙げられる。 カナダのブリティッシュコロンビアやスペインのエストレマドゥラの例は、国家 3 的な教育 ポータルを通じてオープン教材（OER）を利用可能にし、さらに OCW Consortium に参加し ているという点で、インドは OER の開発に対し大規模な投資を行うべきであると主張してい る Indian Knowledge Commission のように、賞賛に值する。その他の国家や地方、州、地域の 権威に対しては、この例と同様に、全ての国々に（中でも特に発展途上国に）利益を与える ための OER プログラムを試してみることを薦める。

\section{機関レベル}

本章では、国家レベルあるいは中間レベルにおける利害関係者や政策決定者などは OER に影響されるだろうということを主張している。この点は、高等教育機関においても、その 機関が OER プロジェクトに参画しているか否かにかかわらず、同様である。何もしないこと のリスクは既に繰り返し述べている。OER を含む新しいビジネスや原価回収モデルに注意を 向けている他機関との競争の激化は、その一例でしかない。他の例としては、機関にとって も、個々の研究者や教育者にとっても、OERの生産・利用に関する共同作業を行う機会が増 加していることが挙げられる。また、第三の例は、教育目的でフリーに利用できるデジタル 資源の増加である。さらに、第四の例は、技術の発達や、若い世代の学生によるインターネ ットやソーシャルソフトウェアの利用の拡大であり、このほかにも様々なリスクがある。ま た、本レポートでは、OERにより誘起された政策課題は、機関内部の教育者の間の協調関係 を強化する機会や、学生に提供される教育の透明性と品質を高める機会、従来は存在しなか ったタイプの学生を援助する機会、教育改革を推進し授業における情報技術の利用を拡大さ せる機会などを創設するといったような、一般的、組織的、教育的な課題と密接に関係して いる、ということも主張した。このことは、各機関に対し、e-Learning に関する課題も含め、 道理の通った情報技術戦略を策定することを要求している。このような戦略は、各機関が OER ムーブメントにより提起された機会や劦威にどのように対処するのか、について概説す るものであるべきである。著作権に関する意識の拡大と明確な政策の策定がこのような戦略 の重要な部分となる。 
OER はカリキュラムや教授法、評価に影響をあたえると期待される。国際的に評価の高い 高等教育機関からフリーに利用可能な多数の（Open Course Ware の）講座が提供されれば、 教員は、学生は自分のカリキュラムを他者のカリキュラムと比べるという可能性について考 慮する必要に迫られるだろう。事例データによれば、既にそうなっていることが示唆されて いる。教授法に関心を向けると、教員の役割は「舞台上の賢者」から「舞台脇の指導者」 と既に変わっている。授業教材の供給者、あるいは単なる知識の指導者としての教員の役割 が減少していることから、OER は上記の変化のプロセスに拍車を掛けるだろう。評価に関し て、ノンフォーマル学習やインフォーマル学習の増加は、おそらく、フォーマル学習以外の 学習環境で取得した能力の認定や評価に対する需要を拡大させるだろう。既に、一部の国で は、そのようなサービスを用意している私的な教育提供者が存在している。今後、OER を利 用することで、手数料の支払いに応じて個人指導、評価、履修証明を用意する私的教育提供 者は増加していくだろう。既存の高等教育機関は、授業機関としての側面を減らし評価組織 としての側面を増大させることで、そのような需要に答える必要に迫られる可能性が高い。

さらに、OERによって創出された機会を活用しようとしている機関は、たくさんの処理す ベき課題を抱えている (その多くは 6.4 節の OER プロジェクトの持続に関する項目で列挙し た)。繰り返し述べるが、最も主要な課題は、教職員の OER 構想への参加の動機を作り出す ために何ができるかを自身に問うてみなければならない、ということである。提案される活 動としては、（OER の）地位保証プロセスの一部として授業一覧またはそれに類するものを 作成すること及び授業上の利点の文書化要求の一部として少なくとも一つの講座を OER の 形式に転換すること、などが挙げられる。その他にも、スキルに乏しい教員でもデジタル資 料を作成でき、しかも同時に、長い目で見ればその教員もデジタル資料の改善に貢献してい ることになるような OER の利用法を考案することで、OER 参加のハードルを下げることが 挙げられる。デジタル学習リソースの生産・利用や著作権法案に関心のある教員や研究者に 対しては、研修が行われるべきである。OER の生産・利用を育成しょうと考えている機関は 互換性の重要性を認識すべきである。ただし、ここでの互換性とは、学習リソースの開発及 び流布に際してオープン標準やオープンソースソフトウェアを利用するというだけでなく、 他の資料との互換性があり、かつ容易に再利用可能な資料を実現するライセンスを用いると いうことを意味している。 


\section{Glossary}

ARIADNE: the Alliance of Remote Instructional Authoring and Distribution Networks for Europe, a European association for knowledge sharing and reuse. The core of the ARIADNE infrastructure is a distributed network of learning repositories.

ATOM: The name Atom applies to a pair of related standards. The Atom Syndication Format is an XML language used for web feeds, while the Atom Publishing Protocol (APP for short) is a simple HTTP-based protocol for creating and updating Web resources.

CERI: Centre for Educational Research and Innovation (OECD)

CMS: Content Management System

CMU: Carnegie Mellon University, USA

EduCommons: an OpenCourseWare management system designed specifically to support OpenCourseWare projects.

ENSTA: École Nationale Supérieure de Techniques Avancées, France

Flash: refers to both the Adobe Flash Player and to a multimedia authoring program used to create content for the Adobe Engagement Platform (such as web applications, games and movies).

FLOSS: Free/Libre Open Source Software

GDP: Gross Domestic Product, the market value of all final goods and services produced within a country in a given period of time.

GLOBE: The Global Learning Objects Brokered Exchange, an international consortium that provides a distributed network of learning objects that meet quality standards.

GNU GPL: Gnu General Public License

H2O: A (playlist) shared list of readings and other content about a topic of intellectual interest. It is a way to group and exchange useful links to information.

HTML: HyperText Markup Language, the predominant markup language for the creation of web pages.

IIEP: International Institute for Educational Planning (UNESCO)

IMS: IMS Global Learning Consortium, a non-profit standards organization concerned with establishing interoperability for learning systems and learning content.

JISC: Joint Information Systems Committee, UK 
MERLOT: Multimedia Education Resource for Learning and Online Teaching

MIT: Massachusetts Institute of Technology, USA

Moodle: Modular Object-Oriented Dynamic Learning Environment, an e-Learning platform built on open source software.

NIME: National Institute of Multimedia Education, Japan

OA: Open Access publishing

OCW: Open Course Ware. A free and open digital publication of high-quality educational materials, organized as courses.

OECD: Organisation for Economic Co-operation and Development

ODF: OpenDocument or ODF, short for the OASIS Open Document Format for Office Applications, a document file format used for exchanging digital documents such as memos, reports, books, spreadsheets, charts, and presentations.

OKI: The Open Knowledge Initiative, an organization responsible for the specification of software interfaces.

OLCOS: Open eLearning Content Observatory Services, EU-funded project.

OSLO: Optics Software for Layout and Optimization, a computer program used to design and optimize optical systems.

OSS: Open Source Software

ParisTech: Paris Institute of Technology, an organisation bringing together 11 publicly-owned educational and research institutions in France.

PDF: Portable Document Format, an open file format created and controlled by Adobe Systems, for representing two-dimensional documents in a device independent and resolution independent fixed-layout document format.

PNG: Portable Network Graphics, a bitmap image format that employs lossless data compression.

Podcasting: A podcast is a media file that is distributed by subscription (paid or unpaid) over the Internet using syndication feeds, for playback on mobile devices and personal computers. Like "radio", it can mean both the content and the method of syndication. The latter may also be termed podcasting.

RoMEO: Rights MEtadata for Open archiving, a one year project (2002-2003) funded by the Joint Information Systems Committee in UK. 
RSS: a family of web feed formats used to publish frequently updated digital content, such as blogs, news feeds or podcasts. Users of RSS content use programs called feed "readers" or "aggregators": the user subscribes to a feed by supplying to their reader a link to the feed; the reader can then check the user's subscribed feeds to see if any of those feeds have new content since the last time it checked, and if so, retrieve that content and present it to the user.

Sakai: A course management system built on open source software.

SCORM: Sharable Content Object Reference, a collection of standards and specifications for web-based e-Learning.

SVG: Scalable Vector Graphics, an XML markup language for describing two-dimensional vector graphics

RTF: The Rich Text Format, a proprietary document file format developed by Microsoft since 1987 for cross-platform document interchange

USU: Utah State University, USA

Videocasting: Video podcast is a term used for the online delivery of video on demand video clip content. The term is an evolution specialized for video, coming from the generally audio-based podcast.

Web feed: a data format used for serving users frequently updated content. It allow software programs to check for updates published on a web site.

Wiki: a website that allows the visitors themselves to easily add, remove, and otherwise edit and change available content, and typically without the need for registration.

XML: The Extensible Markup Language, a general-purpose markup language that supports a wide variety of applications recommended by the World Wide Web Consortium 


\section{付録 $1:$ OER の利用とプロダクションに関する質問票}

\section{イントロダクション}

高等教育(tertiary education)における OER に関するCERI/OECD の研究に参加していただきありがとうござ います。質問は、10〜15 分程度のものとなっております。

この調査は、OER に関する研究の重要な一端を担っています。この研究の目的は、OER 団体において、目 的、コンテンツ、財源などにおける規模と範囲を描くことにあります。また、技術的、法律的なフレームワ ークや、これらの組織を維持するためのコスト/利益モデルを調べもします。

この調查は、OER を利用していたり、作り出したりしている講師や研究者から、定量的、定性的な情報を 抽出します。質問のいくつかは、全ての参加者に対して同様に聞かれるものではありません。この調査を終 えたら、どこがそのような質問であったか教えてください。

いくつかの質問では、数を尋悋ます。もし分からなければ、概算を教えてください。一般的な発見があれば 参加者や、より広範囲で共有されるでしょう。

あなたの回答は、秘密にされます。どのような個人の回答も、許可なしには特定されません。

\section{定義}

この調査では、OERに対して以下のような定義を用います。:OERは、教育者、生徒、自己学習者に対して 教育、学習、研究のために自由に、公開されて提供される、電子化された資源です。

我々の理解では、OER は以下のものを含みます。

1 オープンコースウェアとそのコンテンツ

2 オープンソフトウェアツール(学習支援システム(learning management system))

3 教員の e-Learning 能力開発ためのオープンコンテンツ

4 学習教材のリポジトリ

5 フリーの教育講座

質問を短縮するために、以下では「オープンな学習コンテンツ」を、オープンコースウェアやコンテンツ、 ランニングオブジェクト、教育講座を表す一つの表現として用いる(1,3-5 を参照)。

「オープンソースソフトウェア」は、教育コンテンツを開発・配布するために用いられるソフト ウェアを指し示すために用いる。この調査では、教育コンテンツを開発・配布するため以外の夕 スクに用いられるオープンソースソフトウェアは含まない。 


\section{一般的な質問}

1.あなたが働いている国はどこですか?

2.あなたの所属する機関の学生数はどれくらいですか?

(生徒数。カンマ(,)やスペースを用いないでください。)

3.あなたの所属する機関の性質

\begin{tabular}{|l|l|}
\hline & 一般 \\
\hline & 非営利・個人 \\
\hline & 営利・個人 \\
\hline
\end{tabular}

4.どの分野で働いていますか

\begin{tabular}{|l|l|}
\hline & 教育 \\
\hline & 人文科学、芸術 \\
\hline & 社会学、法律学 \\
\hline & 経営管理学 \\
\hline & 科学、数学、計算機 \\
\hline & 工学、製造、建築 \\
\hline & 農学、獣医学 \\
\hline & 健康、福祉 \\
\hline & サービス \\
\hline & その他 \\
\hline
\end{tabular}

5. OER プロジェクトや機関の一員の場合、プロジェクトの名前、URL を教えてください。 あなたのプロジェクトに関する情報を持つウェブサイトがあれば、URLを入力してください。

オープンな教育コンテンツの生成

6.何らかの OER 活動に参加していますか?

\begin{tabular}{|l|l|l|l|l|l|}
\hline & $\begin{array}{l}\text { はい、おおい } \\
\text { に参加して } \\
\text { います }\end{array}$ & & & & Wいえ、全く \\
& 1 & 2 & 3 & 4 & $\begin{array}{l}\text { 参加してい } \\
\text { ません }\end{array}$ \\
\hline オープン教育コンテンツの利用 & & & & & 5 \\
\hline オープン教育コンテンツの作成 & & & & & \\
\hline
\end{tabular}




\begin{tabular}{|l|l|l|l|l|l|}
\hline OSS の利用 & & & & & \\
\hline OSS の作成 & & & & & \\
\hline
\end{tabular}

7.あなたの機関の管理者レベル(議会、牧師、大臣など)は、以下をサポートしていますか

\begin{tabular}{|l|l|l|l|l|l|}
\hline & $\begin{array}{l}\text { はい,大い } \\
\text { に }\end{array}$ & & & & いいえ、全く \\
\hline & 1 & $\mathbf{2}$ & $\mathbf{3}$ & $\mathbf{4}$ & $\mathbf{5}$ \\
\hline オープン教育コンテンツの利用 & & & & & \\
\hline オープン教育コンテンツの作成 & & & & & \\
\hline OSS の利用 & & & & & \\
\hline $\begin{array}{l}\text { The PRODUCTION of OSS } \\
\text { OSS の作成 }\end{array}$ & & & & & \\
\hline
\end{tabular}

8.あなたは、オープン教育コンテンツを作成するために、他の教育機関の人間と協力していま すか?

複数回答可能

\begin{tabular}{|l|l|}
\hline & いいえ \\
\hline & はい、同じ地域・州で提携しています。 \\
\hline & はい、国のほかの部分と提携しています。 \\
\hline & 明記する事/コメント \\
\hline
\end{tabular}

9. あなたは、オープン教育コンテンツを交換するために、他の教育機関の人間と協力していま すか?

複数回答可能

\begin{tabular}{|l|l|}
\hline & いいえ \\
\hline & はい、同じ地域・州で提携しています。 \\
\hline & はい、国のほかの部分と提携しています。 \\
\hline & 明記する事/コメント \\
\hline
\end{tabular}

10. あなたが作成しているオープン教育コンテンツは、どのように表現できますか? 複数回答可能

\begin{tabular}{|l|l|}
\hline & 講座・プログラム全体として \\
\hline & 講座・プログラムの一部として \\
\hline & 学習教材として \\
\hline & 明記すること・コメント \\
\hline
\end{tabular}


11. 他の同業者たちが、オープン教育コンテンツを作成する約束をする際に最も障害となってい るのは何ですか?

\begin{tabular}{|l|l|l|l|l|l|}
\hline & $\begin{array}{l}\text { 非 常 } \\
\text { 重要 }\end{array}$ & & & & 重要でない \\
\hline & $\mathbf{1}$ & $\mathbf{2}$ & $\mathbf{3}$ & $\mathbf{4}$ & $\mathbf{5}$ \\
\hline 技術の不足 & & & & & \\
\hline 時間の不足 & & & & & \\
\hline ヘードウェアの不足 & & & & & \\
\hline ソフトウェアの不足 & & & & & \\
\hline コンピューターのアクセス手段の不足 & & & & & \\
\hline スタッフが時間と労カーの報償制度の久如 & & & & & \\
\hline スタッフ内での、教育革新に対する興味の久如 & & & & & \\
\hline $\begin{array}{l}\text { オープンコンテンツインシアチブにおけすビジネス } \\
\text { モデルの久如 }\end{array}$ & & & & & \\
\hline 管理層からのサポートの久如 & & & & & \\
\hline
\end{tabular}

12. 他の教師や研究者が使用するために、オープン教育コンテンツに貢献する際に、以下は あなたにとってどれほど重要ですか?

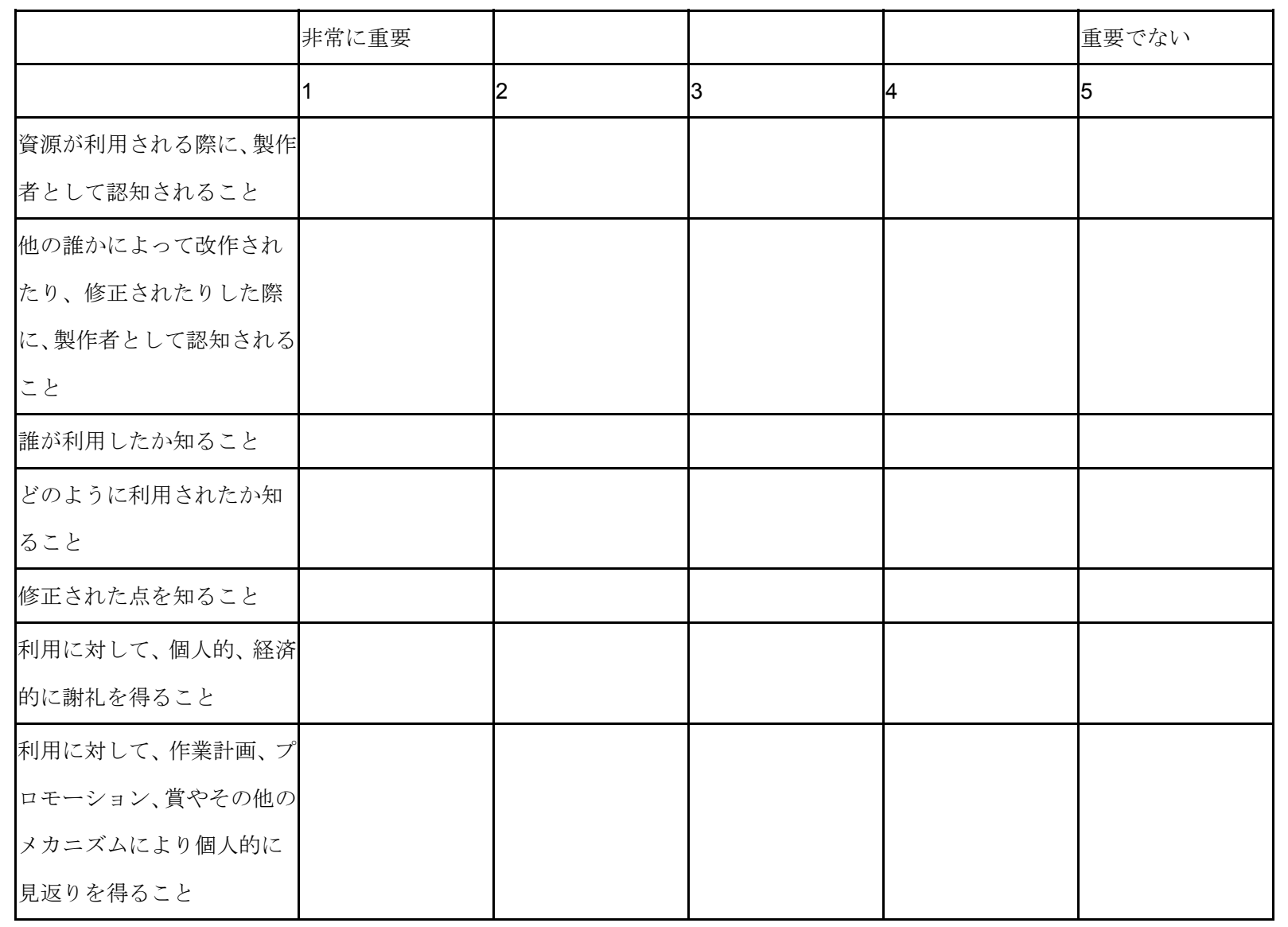




\begin{tabular}{|l|l|l|l|l|l|}
\hline $\begin{array}{l}\text { 利用に対して、グループ・部 } \\
\text { 局、機関が経済的に謝礼を得 }\end{array}$ & & & & & \\
ること & & & & & \\
\hline $\begin{array}{l}\text { 作成物に対して、品質のレビ } \\
\text { ューを受けること }\end{array}$ & & & & & \\
\hline
\end{tabular}

13. あなたの作成物に対して、著作権を主張する何らかのライセンスを用いていますか?

\begin{tabular}{|l|l|}
\hline & いいえ \\
\hline & はい、クリエイティブ・コモンズ・ライセンスを用いています \\
\hline & はい、他の「オープンコンテンツライセンス」を用いています \\
\hline & その他 \\
\hline
\end{tabular}

\section{オープン教育コンテンツの利用}

14. あなたは、オープン教育コンテンツを、あなたの教育・講座の配布に用いていますか?

\begin{tabular}{|l|l|}
\hline & いいえ、まったく \\
\hline & はい、少し \\
\hline & はい、ある程度 \\
\hline & はい、非常に \\
\hline
\end{tabular}

15. 教育や講座の配布においてオープン教育コンテンツを用いることにおいて、どのような目標 や利益を求めていますか?

\begin{tabular}{|l|l|l|l|l|l|}
\hline & 非常に重要 & & & & 重要でない \\
\hline $\begin{array}{l}\text { 利用できる中で最も良いと } \\
\text { 思われる資源へのアクセス } \\
\text { を得ること }\end{array}$ & 1 & 2 & 3 & 4 & 5 \\
\hline $\begin{array}{l}\text { 科学的研究・教育を、一般 } \\
\text { に公開された活動として促 } \\
\text { 進すること }\end{array}$ & & & & & \\
\hline 学生のコストを減らすこと & & & & & \\
\hline 機関が講座を開発するコス \\
トの削減
\end{tabular}




\begin{tabular}{|l|l|l|l|l|l|}
\hline 出版社からの独立 & & & & & \\
\hline より柔軟な資源の作成 & & & & & \\
\hline 研究、開発の実施 & & & & & \\
\hline 維持可能なパートナーシッ & & & & & \\
プの建設 & & & & & \\
\hline その他 & & & & & \\
\hline
\end{tabular}

16. OER の使用における目的と利益に関する前質問に対するコメント

17. あなたが教育、講座配布に用いるオープン教育コンテンツの種類はどのようなものですか? 複数回答可能、ただし些細な利用は除く

\begin{tabular}{|l|l|}
\hline & 講座・プログラム全体 \\
\hline & 講座・プログラムの一部 \\
\hline & 学習教材 \\
\hline & その他 \\
\hline
\end{tabular}

18. あなたが教える、もしくは配布する講座・プログラムの中で、オープン教育コンテンツの利 用率はどれくらいですか?

もし正確な割合が分からなければ、概算を示してください。

\begin{tabular}{|l|l|l|l|l|l|}
\hline & $\begin{array}{l}\text { はい、非常に } \\
\text { 多い }\end{array}$ & & & & いいえ、全く \\
\hline & 1 & $\mathbf{2}$ & $\mathbf{3}$ & $\mathbf{4}$ & $\mathbf{5}$ \\
\hline あなたが作成したもの & & & & & \\
\hline あなたの所属する組織で作られたもの & & & & & \\
\hline $\begin{array}{l}\text { インターネットから自由にダウンロードさ } \\
\text { れたもの }\end{array}$ & & & & & \\
\hline $\begin{array}{l}\text { 既に確立された、他の教育機関との協力か } \\
\text { ら得たもの }\end{array}$ & & & & & \\
\hline $\begin{array}{l}\text { 出版社やそれに類するところから購入した } \\
\text { もの }\end{array}$ & & & & & \\
\hline その他 & & & & & \\
\hline
\end{tabular}


19. 他の同業者にとって、オープン教育コンテンツを教育に用いる際に最も障害となっているこ とは何ですか?

\begin{tabular}{|c|c|c|c|c|c|}
\hline & 非常に重要 & & & & 重要でない \\
\hline & 1 & 2 & 3 & 4 & 5 \\
\hline 技術の不足 & & & & & \\
\hline 時間の不足 & & & & & \\
\hline ハードウェアの不足 & & & & & \\
\hline ソフトウェアの不足 & & & & & \\
\hline $\begin{array}{l}\text { コンピュータへのアクセス } \\
\text { 手段の不足 }\end{array}$ & & & & & \\
\hline $\begin{array}{l}\text { スタッフが時間と労カーの } \\
\text { 報奖制度の欠如 }\end{array}$ & & & & & \\
\hline $\begin{array}{l}\text { スタッフ内での、教育革新 } \\
\text { に対する興味の久如 }\end{array}$ & & & & & \\
\hline $\begin{array}{l}\text { オープンコンテンツイニシ } \\
\text { アチブにおけるビジネスモ } \\
\text { デルの久如 }\end{array}$ & & & & & \\
\hline $\begin{array}{l}\text { 管理層からのサポートの久 } \\
\text { 如 }\end{array}$ & & & & & \\
\hline
\end{tabular}

20. オープン教育コンテンツや、OSS の作成、利用に関して他にコメントはありませんか? 


\section{付録 2：政策グリッド(POLICY GRIDS) の例}

Gird 1: 適切な政策レベルの識別(D’Antoni による)

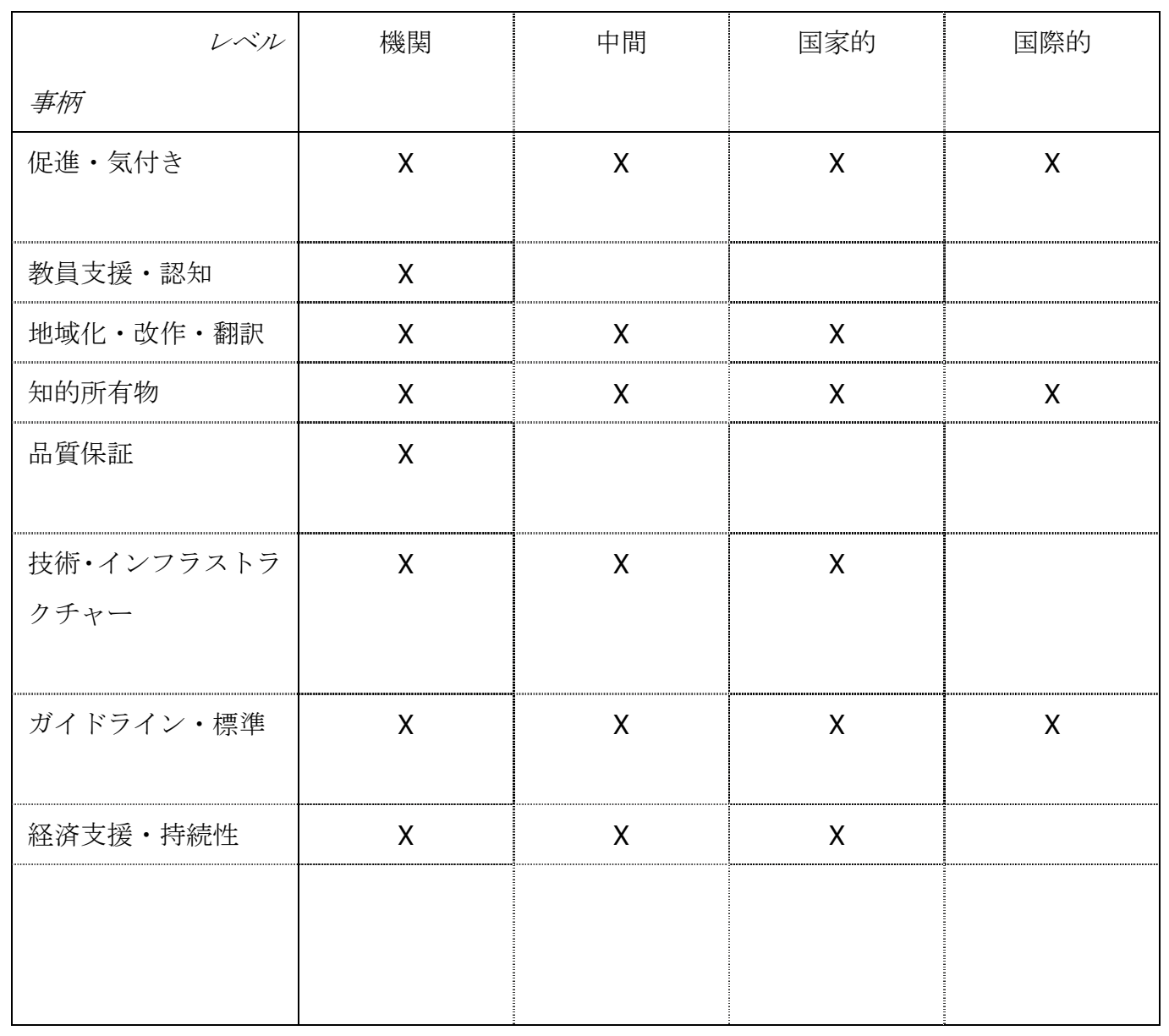


Grid 2:各レベルの政治活動と責任

\begin{tabular}{|c|c|c|c|c|}
\hline $\begin{array}{l}\text { レベル } \\
\text { 事柄 }\end{array}$ & 国際的 & 国家的 & 中間 & 機関 \\
\hline 法律 & $\begin{array}{l}\text {-IPR とオープンスタ } \\
\text { ンダードにおける同 } \\
\text { 意 }\end{array}$ & $\begin{array}{l}\text {-適切な IPR 政治形態 } \\
\text { 標準と相互運用性に } \\
\text { おける協調 }\end{array}$ & $\begin{array}{l}\text { IPR 政策とガイドライ } \\
\text {-オープンスタンダー } \\
\text { ドの置ける協調作業 }\end{array}$ & $\begin{array}{l}\text { IPR 政策とガイドライ } \\
\text {-オープンスタンダー } \\
\text { ドと OSS における政策 }\end{array}$ \\
\hline アクセス & & $\begin{array}{l}\text {-インフラストラクチ } \\
\text { ヤー } \\
\text { 障害の除去 }\end{array}$ & -協調アクセスの機会 & 支援 \\
\hline 財政 & -研究 & $\begin{array}{l}\text {-手法と資源の研究開 } \\
\text { 発 } \\
\text {-標淮化へのスポンサ } \\
\text {-イン動 } \\
\text {-インフラストラクチ } \\
\text { PPP(パブリック、プラ } \\
\text { イベート、パートナー } \\
\text { シップ) }\end{array}$ & $\begin{array}{l}\text {-手法と資源の研究開 } \\
\text {-発 } \\
\text {-教師の訓練 } \\
\text {-PPP }\end{array}$ & $\begin{array}{l}\text { - 報酬システム } \\
\text { - 教師の訓練 } \\
\text {-PPP }\end{array}$ \\
\hline $\begin{array}{l}\text { 素材の } \\
\text { Curation }\end{array}$ & & $\begin{array}{l}\text { 公文書と博物館収集 } \\
\text { 品の公開 }\end{array}$ & $\begin{array}{l}\text {-公文書と博物館収集 } \\
\text { 品の公開 }\end{array}$ & $\begin{array}{l}\text {-大学図書サービスの } \\
\vdots \text { 支援 } \\
\text {-教師の支援 }\end{array}$ \\
\hline & & & & \\
\hline
\end{tabular}




\section{参考文献}

Abel, R: (2006) "Best Practices in Open Source in Higher Education Study - The State of Open Source Software" (March, 2006). Lake Mary, FL, The Alliance for Higher Education Competitiveness, Inc.

Albright, P: (2005) “Final Forum Report”, UNESCO International Institute for Educational Planning, Internet Discussion Forum on Open Educational Resources

Alexander, B: (2006) "Web 2.0 - A New Wave of Innovation for Teaching and learning?" Educause Review March/April 2006

Bateman, P: (2006) "The AVU, Open Educational Resources Architecture for Higher Education in Africa", available at www.oecd.org/edu/oer

Benkler, Y: (2005) “Common Wisdom: Peer Production of Educational Materials”, available at http://www.benkler.org/Common_Wisdom.pdf\#search $=\% 22 \% \mathrm{E} 2 \% 80 \% 9 \mathrm{CCommon} \% 20 \mathrm{Wis}$ dom $\% 3 \mathrm{~A} \% 20$ Peer $\% 20$ Production $\% 20$ of $\% 20$ Educational $\% 20$ Materials $\%$ E2\%80\%9D $\% 2 \mathrm{C} \%$ $20 \% 22$

Benkler, Y: (2006) "The Wealth of Networks, How Social Production Transforms Markets and Freedom”, Yale University Press, New Haven and London 2006.

Beshears, F: (2005) Viewpoint: The Economic Case for Creative Commons Textbooks Campus Technology (September 2005) (http://www.campus-technology.com/print.asp?ID=11891)

Carson, S: (2004) "MIT OpenCourseWare Program Evaluation Findings, Summary Report" (March 2004), available at http://www.myoops.org/cocw/mit/NR/rdonlyres/250BF523-3FA0-49AB-A78B-C6633D6E6 66A/0/Program Summary March 2004.pdf

Carson, S: (2005) "2004 MIT OCW Program Evaluation Findings Report" available at http://ocw.mit.edu/OcwWeb/Global/AboutOCW/evaluation.htm

Carson, S: (2006a) "2005 Program Evaluation Findings Report - MIT OpenCourseWare.” June 5, 2006. 
Carson, S: (2006b) "Open sharing, global benefits", Presentation at the OpenEd Conference at Utah State University, September 2006.

Committee for Economic Development (CED): (2006) "Open Standards, Open Source, and Open Innovation: Harnessing the Benefits of Openness"

D'Antoni, S. in Daniel, Sir John, et.al. (2006): eLearning and Free Open Source Software: the Key to Global Mass Higher Education? Malaysia. Commonwealth of Learning http://www.col.org/speeches/JD 0601eLearningKualaLumpur.htm

Dholakia, U., King, J., Baraniuk, R.: (2006) "What Makes and Open Education Program Sustainable? The Case of Connexions" available at

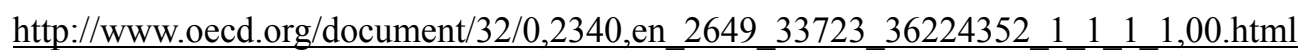

D’Oliveira, C.: (2006) “OCW Publication Formats: User Needs and Future Directions”, available at http://www.tofp.org/reports/OCW_Pub_Formats.doc

Downes, S: (2006) "Models for Sustainable Open Educational Resources", National Research Council Canada available at

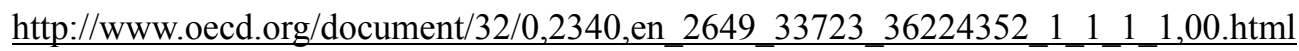

European Commission: (2001) "Symposium on use of open source software in EU public administrations" available at http://www.isoc.lu/agenda/evenement/symposium-on-use-of-open-source-software-in-eu-pu blic-administrations/

European Commission: (2005) "Bulletin EU 3-2005. Presidency conclusions (6/12)" available at http://europa.eu/bulletin/en/200503/i1007.htm

European Schoolnet: (2006) "MELT Content Enrichment Project, Part B: Description of Objectives and Workplan", eContentplus Programme 2006.

Fisher, W and McGeveran, W: (2006) "The Digital Learning Challenge: Obstacles to Educational Uses of Copyrighted Material in the Digital Age. A Foundational White Paper" Research Publication No. 2006-09, (August, 2006) available at http://cyber.law.harvard.edu/publications

Fitzgerald, B; Fitzgerald, A; Perry, M; Kiel-Chrisholm, S; Driscoll, E; Thampapillai, D; Coates, J: (2006) "OAK Law Report Number 1. Creating a legal framework for copyright management of open access within the Australian academic and research sector." (August 2006). 
Fitzgerald, B: (2006) “Open Licensing (OCL) for Open Educational resources” available at www.oecd.org/edu/oer

Gadd, E, Oppenheim, C, Probets, S: (2003) RoMEO Studies 2: "How academics want to protect their open-access research papers” Department of Information Science, Loughborough University available at http://www.lboro.ac.uk/departments/ls/disresearch/romeo/RoMEO\%20Studies\%202.pdf

Glance, D, Kerr, J, Reid, A: (2004) "Factors affecting the use of open source software in tertiary education institutions" First Monday, volume 9, number 2 (February 2004).

Gowers, A: (2006) “Gowers Review of Intellectual Property” (December 2006) available at http://www.hm-treasury.gov.uk/media/583/91/pbr06_gowers_report_755.pdf

Hanley, G: (2005) "Enabling Open Education with MERLOT", Proceedings from the OpenEd Conference at Utah State University, September 2005.

Harley, D et al.: (2006) "Use and Users of Digital Resources - A Focus on Undergraduate Education in the Humanities and Social Sciences." Center for Studies in Higher Education, UC Berkley, April 2006.

Hilton, J: (2006) “The Future for Higher Education - Sunrise or Perfect Storm?” Educause Review March/April 2006

Hylén, J: (2006) "ParisTech 'Graduate School' - A Case Study in Open Educational Resources Production and Use in Higher Education"

International Council for Open and Distance Education (ICDE): (2006) "Report from the 29th Southeast Asian Ministers of Education Organization High Officials Meeting”, 22-24 November, Bangkok, Thailand.

Johannesen, Ø: “Open Educational Resources: Policy Implications”, Presentation at Barcelona Expert meeting, October 2006.

Johnstone, M and Poulin, R: (2002) "What is opencourseware and why does it matter?" in Change, Volume 34(4), July/August 2002.

Johnstone, S: (2005) “Open Educational Resources and Open Content, Background note". International Institute for Educational Planning, Internet Discussion Forum on Open Educational Resources, Open Content for Higher Education. 
Joint Information Systems Committee (JISC): (2006) Digital Preservation - Continued access to authentic digital assets. Briefing Paper" (November 2006) available at http://www.jisc.ac.uk/publications/publications/pub digipreservationbp.aspx

Kim, K-J and Bonk, C: (2006) "The Future of Online Teaching and Learning in Higher Education: The Survey Says...” Number 4, 2006, Educause Quarterly

Kirschner, P, Varwijk, P, van Dorp, K-J, Lane, A: (2006) "Open Educational Resources in Europe: A Triptych of Actions to Support Participation in Higher Education”, in Proceedings from the OpenEd Conference at Utah State University, September 2006.

Kumar, V: (2006) Opening Educational Opportunity in India (PowerPoint presentation at Second OECD Expert Meeting on OER, Barcelona, 26 October, 2006).

Kobayashi, T, and Kawafuchi, A: (2006) "Japan OCW Consortium (JOCW) - A Case Study in Open Educational resources Production and Use in Higher Education" (July, 2006)

Koppi, T, Bogle, L, Lavitt, N: (2003) "Institutional Use of Learning Objects Three Years on: Lessons Learned and Future Directions", University of New South Wales, Australia

Lerman, S and Miyagawa, S: (2002) "Open Course Ware - A Case Study in Institutional Decision Making" Academe, Volume 88(5), September/October 2002. Available at http://www.aaup.org/publications/Academe/2002/02so/02soler.htm

Margulies, A: (2005) "MIT Opencourseware - A New Model for Open Sharing", Presentation at the OpenEd Conference at Utah State University, September 2005.

Materu, P: (2004) “Open Source Courseware: a baseline study”, The World Bank

McAndrew, P: (2006) "Motivations for OpenLearn: the Open University's Open Content Initiative." October 2006 available at www.oecd.org/edu/oer

McCracken, R: (2006) "Cultural responses to open licences and the accessibility and usability of open educational resources" available at

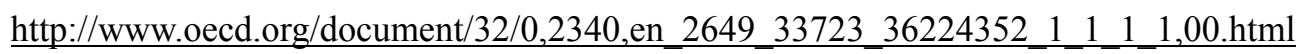

Merlot: (2006) "Putting Educational Innovations into Practice", (PowerPoint presentation at Second OECD Expert Meeting on OER, Barcelona, 26 October, 2006).

Moore, A.: (2002) "Lens on the future: open-source learning", Educause Review, Volume 37(5), September/October 2002. 
Mulder, F: (2006) "The advancement of Lifelong Learning through Open Educational Resources in an open and flexible (self)learning context"

Möller, E: (2005) "The Case for Free Use: Reasons Not to Use a Creative Commons - NC License" available at http://intelligentdesigns.net/Licenses/NC

Nature (2006): "Overview: Nature's peer review trial” (December 2006) available at http://www.nature.com/nature/peerreview/debate/nature05535.html

Ng, W-Y: (2006) "Rational Sharing and its Limits", paper presented at FM10 Openness: Code, Science and Content.

OECD (2001) "E-Learning: The Partnership Challenge", OECD, Paris.

OECD: (2005) “E-learning in Tertiary Education - Where do we stand?", OECD, Paris.

OECD: (2006a) "Education Policy Analysis: Focus on Higher Education - 2005-2006 Edition", OECD, Paris

OECD: (2006b) "Participate Web: User Created Content”, Rev1, OECD, Paris.

O’Hear, S: (2006) "E-learning 2.0 - how Web technologies are shaping education" (August 8, 2006) available at http://www.readwriteweb.com/archives/e-learning_20.php

Open eLearning Content Observatory Services (OLCOS): (2007) Open Educational Practices and Resources. OLCOS Roadmap 2012. Edited by G Geser, Salzburg Research, EduMedia Group. Salzburg, January 2007, available at http://www.olcos.org

Pedró, F: (2006a) "The Instituto Tecnológico de Monterrey, a Case Study in Open Educational Resources Production and Use in Higher Education" (OECD March 2006)

Pedró, F: (2006b) "The Spanish Region of Extremadura. A Case Study on the Interplay between Government and Universities in the Production and Use of Open Educational Resources in Higher Education" (OECD, November 2006)"

Pedró, F: (2006c) "The Spanish National University of Distance Teaching, UNED. A Case Study in Open Educational Resources Production and Use in Higher Education" (OECD, November 2006)

Phelps, M: (2006a) "John Hopkins University, Bloomberg School of Public Health - A Case Study of the Production of OpenCourseWare" (OECD, October 2006) 
Phelps, M: (2006b) "Tufts University - A Case Study on Production and Use of Open Education Resources" (OECD, October 2006)

Powers, E: (2006) "Open to Open Source" (March 1, 2006) http://insidehighered.com/news/2006/03/01/open

Sale, A: (2006) "Comparison of content policies for institutional repositories in Australia", First Monday, volume 11, number 4 (April 2006)

Schuller, T: (2006) "Open University UK: Open Content Initiative. OER Site Visit Report" (June 2006)

Siemens, G: (2003) "Why We Should Share Learning Resources" available at http://www.elearnspace.org/Articles/why we should share.htm

Sloan Consortium: (2006) "Making the Grade: Online Education in the United States, 2006" available at http://www.sloan-c.org/publications/survey/index.asp

Stacey, P: (2006) “Open Educational Resources in a Global Context” June 2006.

Stacey, P and Rominger, R: (2006) "A Dialogue on Open Educational Resources (OER) and Social Authoring Models". Proceedings from the OpenEd Conference at Utah State University, September 2006.

Stephenson, R: (2005) "How to Make Open Education Succeed". Proceedings from the OpenEd Conference at Utah State University, September 2005.

Stewart, W: (2006) "Athabasca University - A Case Study in Open Educational Resources Production and Use in Canada" (OECD, May 2006)

Stunden, A: (2003) "The Muscles, Aches, and Pains of Open Source” in EDUCAUSE Review, vol. 38, no. 6 (November/December 2003): 100-101

Suzor, N: (2006a) "Macquarie University - A case study in the use and production of open education resources and open source software" (OECD, July 2006)

Suzor, N: (2006b) "AEShareNet - A case study in the use and production of open education resources and open source software" (OECD, August 2006) 
Taylor, P: (2002) "Quality and Web-based learning objects: Towards a more constructive dialogue", HERDSA, page $656 \mathrm{ff}$ available at http://www.ecu.edu.au/conferences/herdsa/main/papers/ref/pdf/TaylorP.pdf\#search=\%22Qual ity\%20and\%20Web-based\%20learning\%20objects\%3A\%20Towards\%20a\%20more\%20cons tructive $\% 20$ dialogue $\% 22$

The New Media Consortium: (2006) "The Horizon Report 2006 Edition” available at http://www.nmc.org/pdf/2006_Horizon_Report.pdf

The Open Knowledge Foundation (2006): http://www.okfn.org

Tufts OCW Quarterly Newsletter, July 2006, Volume 1, Issue 2 available at http://ocw.tufts.edu

Tuomi, I: (2005) “The Future of Open Source”, in Wynants, M \& Cornelis, J (eds.) How Open is the Future? VUB Brussels University Press, pp. 429-59.

Tuomi, I: (2006) "Open Educational Resources: What they are and why do they matter" (October, 2006) available at www.oecd.org/edu/oer

UNESCO/IIEP: (2002) http://www.unesco.org/iiep/virtualuniversity/forums.php

UNESCO/IIEP: (2006) "OER Useful resources"

http://oerwiki.iiep-unesco.org/index.php?title=Main_Page

UNU-MERIT: (2006) "Study on the: Economic impact of open source software on innovation and the competitiveness of the Information and Communication Technologies (ICT) sector in the EU'. Final report, (November 20, 2006).

Vest, C: (2004) "Why MIT Decided to Give Away All Its Course Materials via the Internet." The Chronicle of Higher Education, January 30, 2004 p. 20.

Walli, S: (2005) "Open Source and Open Standards: The Business Models in Context”, in Bolin, S: The Standards Edge: Open Season 2005, Bolin Communications 2005, page 43.

Weber, S: (2004) “The Success of Open Source”, Harvard University Press, Cambridge Massachusetts

Werry, C: (2001) "The Work of Education in the Age of E-College", First Monday 6, no. 5 (May 2001) available at http://firstmonday.org/issues/issue6_5/werry/index.html 
Wiley, D: (1998) “OpenContent" available at http://web.archive.org/web/19991012095550/opencontent.org/home.shtml

Wiley, D: (2005) "Thoughts from the Hewlett Open Ed Grantees Meeting Utah, 2005." iterating toward openness. Available at http://opencontent.org/blog/archives/192

Wiley, D: (2006a) "The Current State of Open Educational Resources" available at http://www.oecd.org/document/32/0,2340,en_2649 $33723 \quad 36224352 \quad 1 \quad 1 \quad 1 \quad 1,00 . h t m l$

Wiley, D: (2006b) "On the Sustainability of Open Educational Resource Initiatives in Higher Education" available at www.oecd.org/edu/oer

Wiley, D: (2006c) “The Learning Objects Literature: Bifurcations, Criticisms, and Openness”

Zalta, E: (2005) “A New Model for Open Access to Scholarly and Educational Content”, Proceedings from the OpenEd Conference at Utah State University, September 2005. 


\section{Also available in the CERI collection}

Understanding the Brain: The Birth of a Learning Science

255 pages · June 2007 : ISBN: 978-92-64-02912-5

Demand-Sensitive Schooling? Evidence and Issues

146 pages • November 2006 • ISBN: 978-92-64-02840-4

Think Scenarios, Rethink Education

200 pages • April 2006 : ISBN: 978-92-64-02363-1

Personalising Education

128 pages : February 2006 - ISBN: 978-92-64-03659-8

E-learning in Tertiary Education: Where do We Stand?

290 pages : June 2005 - ISBN: 978-92-64-00920-5

Formative Assessment - Improving Learning in Secondary Classrooms

280 pages - February 2005 - ISBN: 978-92-64-00739-3

Quality and Recognition in Higher Education: The Cross-border Challenge

205 pages • October 2004 - ISBN: 978-92-64-01508-6

Internationalisation and Trade in Higher Education - Opportunities and Challenges

250 pages : June 2004 : ISBN: 978-92-64-01504-3

Innovation in the Knowledge Economy - Implications for Education and Learning

Knowledge Management series

96 pages : May 2004 - ISBN: 978-92-64-10560-3 


\section{ONIME 研究報告及びメディア教育研究のバックナンバーリスト}

インターネットからも利用が可能です(http://www.nime.ac.jp/journal/)。

\section{NIME 研究報告}

第 1 号 平成17年 3 月 効果的な遠隔教育 $/ \mathrm{e}-$ Learning 実施の視点

清水 康敬・伊藤 秀子・佐賀 啓男・高比良美詠子・波多野和彦・吉田 文

第 2 号 平成 17 年 3 月 高等教育機関における IT 利用実態調查 $(2003$ 年度)

一 IT 利用に関寸る調查研究—

吉田＼cjkstart文・田口 真奈

第 3 号 平成 17 年 3 月 exCampus:e ラーニングサイト構築支援ソフトウエアの開発と評価

中原淳・西森 年寿

第 4 号 平成 17 年 3 月 教育の将来像検討のための情報技術予測調査

平本 健二・清水 康敬

第 5 号 平成 17 年 3 月 高等教育分野における引用をめぐるトラブルとその対処

一学習者向けコンテンツ配信及び著作権に関する研究—

青木 早苗

第 6 号 平成 17 年 3 月 日本の大学生の基礎学力構造とリメディアル教育

一 IT 活用学力支援研究一

小野 博 - 村木 英治 - 林 規生 - 杉森 直樹 - 野崎 浩成

西森 年寿・馬場眞知子 $\cdot$ 田中 佳子・國吉 丈夫・酒井 志延

第 7 号 平成 17 年 3 月 フレキシブル・ラーニング環境における授業づくり

一実践的な「授業の設計・実施・評価・改善」の試み一

波多野和彦

第 8 号 平成 17 年 3 月 メディア FD の基礎的検討一メディア FD に関する研究開発一

山地 弘起

第 9 号 平成 17 年 3 月 ICT が拓く多様な学生への支援:障害者支援が大学を変える

広瀬 洋子

第 10 号 平成 17 年 3 月 人間とロボットの相互作用に関する実証的研究

橿淵めぐみ・黒須 正明・坂元＼cjkstart章

第 11 号 平成17年10月 学習スタイルの概念と理論及びそれに基づく測定方法

一欧米の研究加ら日本独自の研究への考察—

青木久美子

第12号 平成18年 2 月 衛星回線上の IP 網とインターネットとの品質比較実験

一実時間マルチメディアコミュニケーションシステム研究—

次世代 SCS 検討ワーキンググループ 
第13号 平成18年 2 月 大学における e ラーニングの実態に関する調査研究 一 IT 利用に関する調查研究—

田口 真奈·吉田 文

第 14 号 平成 18 年 2 月 ICT が拓く多様な学生への支援 2 : 大学の情報保障の現在と新たな技術開発 広瀬 洋子

第15号 平成18年 2 月 ICT を活用した国際交流活動の現状と課題

一2004 年度 全国四年制大学対象のアンケート調査の結果から一

青木久美子・小林登志生

第16号 平成18年 3 月 高等教育機関における IT 利用実態調查(2004 年度)

吉田 文・田口 真奈

第17号 平成18年 3月 マイクロシナリオ手法

黒須 正明

第18号 平成18年 3月＼cjkstart衛星による大学間コラボレーションシステム(SCS)の開発と評価

第19号 平成18年 3 月 ロボットと人間の相互作用に関する実証的研究

近藤喜美夫

一愛・地球博での現場実験—

橿淵めぐみ・黒須 正明・坂元 章・長田 純一

第20号 平成18年 3 月 FD 形態に関する事例検討

一教授能力向上の手法の分析と評価に関寸る研究開発一

山地 弘起

第21号 平成18年 3 月「教育のための 3 D コンテンツ配信・利用技術の研究」にかかわる実践活 動の記録

波多野和彦

第22号 平成19年 2 月 教育用映像/画像/ 3 D コンテンツのデータベース化と検索

柳沼 良知・鈴木 一史

第23号 平成19年 2 月 視線情報に基づく機器操作支援システムの構築と評価

浅井紀久夫

第24号 平成19年 2月 NIME-gladビデオ検索システムの開発と利用状況

森本 容介

第25号 平成19年 3月 高等教育授業シラバスのWebからの自動抽出

一自然言語処理を利用した自動抽出法とその結果一

地蔵 真作・篠原 正典

第26号 平成19年 3 月 WebアンケートシステムREASの開発とその機能拡張

一「デジタルコンテンツ評価支援システムの研究開発」プロジェクト一

芝崎 順司 - 近藤 智嗣 
第27号 平成19年 3月 ICT活用による学校業務の高度化のための調査および研究開発

一株式会社内田洋行との包括連携協定による「UNIQUEプロジェクト」の成果 報告一

堀田 龍也

第28号 平成19年 3 月 学習コンテンツの開発とその共有化・協創化のための著作権管理

览玉 晴男

第29号 平成19年 3 月 複合現実感技術の教育応用

近藤 智嗣

第30号 平成19年 3 月 国際遠隔教育コミュニケーションネットワークに関する研究開発プロジェクト

一オーセンテイックな知の発信を目指して一

小林登志生

第31号 平成19年 3 月 大学における学習者同定に関する技術と運用に関する調査

葉田 善章・辻 靖彦・西森 年寿・稲葉利江子・清水 康敬

第32号 平成19年 3 月 K-tai Campus:携帯電話による大学情報配信システムの開発とその利用

葉田 善章・篠原 正典・清水 康敬

第33号 平成19年 3 月 ICT が拓く多様な学生への支援 $3:$ ICT を活用した講義のユニバーサルデザイ ン化

広瀬 洋子

第34号 平成19年 3 月 アメリカの大学におけるメディア利用の教員支援

一教員の教育力向上の関する研究—

苑 復傑・佐賀 啓男 ・波多野和彦・清水 康敬 


\section{メディア教育研究 第1巻 第1号 通巻第 1 号 平成16年(2004年)12月}

特集:学部教育、大学院教育への $\mathrm{e}^{-}$Learning の実践一単位認定 $\mathrm{e}^{-}$-Learning と教育改革一

高等教育における $\mathrm{e}-$ Learning の支援と教育コンテンツの共有

信州大学インターネット大学院の現状と将来計画

清水 康敬 1

不破 泰・國宗 永佳・新村 正明 - 和崎 克己 - 師玉 康成・ 中村 八束 11 東北大学インターネットスクールの実践と課題

学部教育における e ラーニングの利用と評価

$$
\text { 三石大・岩崎＼cjkstart信 } 19
$$

穂屋下 茂 31

九州工業大学における $\mathrm{e}-$ Learning の実践

大西 淑雅・山口真之介・西野 和典・小林 史典 45

玉川大学における e ラーニングの取り組み

橋本 順一 59

プロジェクトベースの e ラーニング導入一専門的人材の育成へ向けて

松田 岳士 73

コース管理システムの発展と我が国の高等教育機関への波及

梶田 将司 85

Globalization of Higher Education through E-Learning:

Case Studies of Virtual Universities based on International Collaboration of

Universities across National Boarders

Kumiko Aoki 99

論文

DVD 映画教材利用時の英語字幕が英語学習に与える影響について

教育用計算機システムシミュレータ ED21 の設計と評価

植松 茂男 107

三浦 義之・金子 敬一・中川 正樹 115

研究資料

携帯電話端末から利用できる復習用ウェブサイトを活用した大学教養教育の実践及び

利用頻度と成績との関係

高専の特色と目的にかなった英語教材の開発

広谷 博史 123

青山 晶子・亀山 太一・平岡 禎一 ・大谷 浩 $・$ 工藤 雅之・武田 淳

村井三千男 - 小澤 志朗 瀬川 直美 - 森岡 隆 - 西野 達雄 $\cdot$ 中井 大造

南優次・穴井 孝義 129

光ファイバスプリッタを用いた1対多の動画像マルチキャステイング手法の評価

奥田 篤士・谷口 和也 ・金子 智彦 $\cdot$ 田中 光也・桜井 哲真 141

研究展望

研究と教育のパラドックス、並びに教育評価への展望

真柄 鉄次 149 


\section{メディア教育研究 第1巻 第 2 号 通巻第 2 号 平成 17 年(2005年) 3 月}

特集: 高等教育における生涯学習への $\mathrm{e}-$ Learning の実践一新たなる $\mathrm{e}-$ Learning の実践一

国際ネットワーク大学コンソーシアムにおける e ラーニングの取り組みについて

国際ネットワーク大学コンソーシアム事務局 1

理工系の知識共有に向けた e-Learning の実証研究

小松川 浩 11

熊本大学 $\mathrm{e}^{-}$-Learning station の試行と展望

中野 裕司・鈴木 和久 ・太田 泰史・喜屋武 毅

清水百合子・野口 千里・喜多 敏博・秋山 秀典 23

学びの共同体と地域コミュニティの活性化一インターネット市民塾から見えてくるもの一

山西 潤一・㭗富雄 35

e-Learning による大学通信教育課程の実践一早稲田大学人間科学部 e スクールの取り組み一

八洲学園大学における e ラーニング・システムの現状と課題

西村 昭治 45

浅井 経子 59

論文

オープンソース学習管理システム CFIVE の開発と運用

関谷 貴之・寺脇 由紀・尾上 能之・山口 和紀 73 通常教室における講義のデジタルコンテンツ自動作成システムの試作

米川輝・立花 綱治・相田 達也・若原 裕範・岩月 正見 83

研究資料

オンデマンド授業のための高画質コンテンツの作成と評価一高等教育における試み一

青木 謙二・久保田真一郎・鍵山 茂徳 91

視覚障害者のプレゼンテーション

村上 佳久 103

電子工学分野における結晶構造描画表示システムの開発

杉浦 藤虎・小澤 功・塚本 武彦・安藤 浩哉 113 高等教育における聴覚障害学生用オルタナティブ・ビデオ学習教材導入の試み

植木 克美・後藤 守・渡部 信一 123

対面式多人数授業の IT 化一電子黒板を活用した語学教育の実践と成果研究一

山崎 吉朗 133

携帯電話によるEラーニングを活用した大学多人数講義での運用実験

九里 徳泰 145

$* *$ 海外高等教育事情 $* *$

欧州における高等教育の障害者支援 HEAG データベース

広瀬 洋子 155

研究展望

Web 上の高等教育用コンテンツの統合検索の課題と効果的検索への提案

IT を利用した大卒女性の再就業:在宅ワークの可能性

篠原 正典・地蔵 真作 169

笹川あゆみ 181 


\section{メディア教育研究 第2巻 第1号 通巻第3号 平成17年(2005年) 10 月}

特集: $\mathrm{e}-$ Learning と教材コンテンツ流通に向けて動き始めた組織連携

東京大学における教育の情報化の取り組み

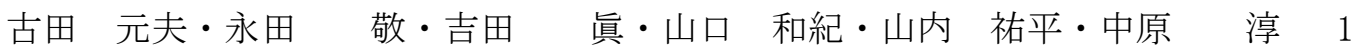
e-Learning による教育支援の組織への適用一岐阜大学 AIMS-Gifu の展開一

オンデマンド授業流通フォーラムによる新たな教育への取り組み

加藤 直樹・村瀬康一郎・益子 典文 17

TIES の挑戦:教育の公開と e ラーニングの活用

学習コンテンツ共有再利用の国際連携における諸問題

高木 直二 29

中嶋 航一 43

山田 恒夫 55

論文

発言者割り当て方式を採用した電子掲示板によるコミュニティ形成支援

ーコミュニティ・インキュベータの概念および実践利用—

e-Learning における適応的コンテンツ配信制御

鈴木 栄幸・舟生日出男 71

吉田 賢史・宮崎 光二・中上香代子・中山 弘隆 81

研究資料

テレビ会議を利用した合同発表会の取り組みと学習効果

一大学と高専の異校種間交流学習を通して一

成瀬 喜則・宮地 功 93

Platforms of Distance Learning Support - the Analysis and the Compatibility -

Vyacheslav Valuisky 103

オンライン日本語語彙コースの開発

佐藤勢紀子・佐藤 保子・虫明 美喜・吉本 啓 113

大学生のための英語リメディアル教育 $\mathrm{e}-$ Learning 教材“University Voices”の開発

國吉 丈夫・神保 尚武 - 石田 雅近 - 木村 松雄 - 酒井 志延 - 笹島 茂 - 生内 裕子

河内山晶子 - 染谷 泰正 $\cdot$ Renée A.Sawazaki Elizabeth J.Lange ・ 中原 淳 - 小野 博 121 静岡大学情報学部「情報社会デザインプログラム」におけるメディア教育の構築

森野 聡子 137

Practice of Online Chat Communication between Two Countries and across Different Curricula

Ritsuko,Saito $\cdot$ Noriko Ishizuka 151

Computer-Mediated Communication における対人相互作用場面の心理学的分析

一対人信頼感、攻撃性および感情制御スキルの検討一

松田 英子・岡田 孝二 159

日本語読解 $\mathrm{e}-$ Learning システム評価一日本語教師と外国人留学生の視点の相違を中心に一

KT 法を改良したグループ演習における個人の成績評価方法の提案

加藤由香里 175

八重樫理人 - 井戸 孝昭 - 小田切和也 - 多々内允晴 ・古宮 誠一 189

研究展望

学習スタイルの概念と理論一欧米の研究から学ぶ

青木久美子 197 


\section{メディア教育研究 第2巻 第2号 通巻第4号 平成18年(2006年) 2 月}

特集:教育ニーズを捉えた特色ある e - learning

北海道大学「大学院・社会人教育支援 $e^{-}$カリキュラム」における脳科学コンテンツの制作 と実践

石川 貴彦・大森 隆司・眞鍋 豊孝・大塚 尚広・山本 強・本間 利久 1 教材開発と e-Learning の学内普及一向けての取り組み（金沢大学）

鈴木 恒雄・井町 智彦・笠原 禎也・佐藤 正英・

車古 正樹・高田 良宏・松本 豊司・森祥寬・堀井 祐介 11

徳島大学におけるユビキタスラーニング (u-Learning)の取り組み

九州大学におけるWB Tによる医療系教育

緒方 広明・矢野 米雄 19

大喜 雅文・井上 仁・石川 邦夫・大池美也子・吉田 素文 29

安全・安心社会の創成を支援する e ラーニング

一長岡技術科学大学での e ラーニングの研究実践—— 福村 好美・丸山 久一 37

時空を越えた教育環境構築の試み (法政大学)

小林 尚登・八名 和夫 ・林 公美 $\cdot$ 日野 好幸 51

論文

シミュレータを中心としたマルチメディア教材の構成とその効果

教育映像コンテンツのビデオポッドキャスティングとブラウジング

須田＼cjkstart宇宙・三井田惊一 59

柳沼 良知・鈴木 一史・清水 康敬 69

研究資料

多様なメディアを利用した同期型遠隔講義環境の構築・実践

長谷川 忍・但馬 陽一・二ツ寺政友・安藤 敏也 79

\section{メディア教育研究 第3巻 第1号 通巻第5号 平成18年(2006年) 10 月}

特集：I C T 活用授業を通した国際連携

国際連携による地球・環境科学教育〜三ヶ国間の実時間型国際遠隔講義〜（京都大学）

中村 裕一・中村 素典・藤井 滋穂・津野 洋・荒木 光彦 1

モジュール交換方式を用いた国際遠隔授業の取り組み (岐阜大学)

青柳 孝洋・今井 亜湖・江馬 諭・加藤 直樹・小林 一貴

西澤 康夫・廣田 則夫・松原 正也・山田 敏弘・Sonia Mycak 9

e ラーニングによる国際連携の課題一専門人材育成による貢献（青山学院大学）

松田 岳士・齋藤＼cjkstart裕・玉木 欽也 19

中国語教育におけるサイバーレクチャの実施（関西大学）片岡 昇 27

I C T を活用した国際連携: 東京工業大学からタイの高等教育機関への衛星講義配信の事例

山口しのぶ・西原 明法・高田 潤一・三輪眞木子 35

遠隔技術を利用した国際連携授業一Technology as a Tool一（大阪学院大学）

中嶌 康二 43

論文

初等複素関数の特性に関するW B T 開発とその評価

藤井 康寿・板倉 俊介・中川 建治 55 
研究資料

Utilizing video streaming technologies for English e-Learning presentation tutorials 一英語プレゼンテーション指導に於けるビデオ録画システムの教育利用一

入所高齢者向け生活感向上システム

飯沼 瑞穂・板宮 朋基・千代倉弘明 65

花田 英輔・池淵 建司・宮本 守 73

e-1earning における産・学・官連携と国際的協力の可能性一韓国サイバー大学のケース・

スタディー

朴 英元・児玉 晴男 79

教育機関における著作物複製ガイドラインに準拠した資料複製・配布システムの提案とその 実装方法

八重堅理人・小田切和也・大山 貞雄・多々内允晴 91

Development of Interactive Educational Support Tool and Its Learning Effect

Tomoo Shishido Yukio Mori $\cdot$ Naoyuki Aikawa Yasuyuki Nishida $\cdot$ Uwe Drofenik Johann W. Kolar

サービス指向に基づいた e-Learning システムの開発手法一携帯電話向けアンケート調查サ ービスの開発を例にして一

携帯電話を用いた情報配信システムによる高等教育機関へのサービス提供

黒田 亮平・辻 光宏 109 葉田 善章・篠原 正典・清水 康敬 117

研究開発速報

計算機シミュレータとラジコンカーを用いた計算機の動作原理教育

木室 義彦・松本三千人・安浦 寛人 125

報告

e-Journal によるアーカイブ型 e-learning 支援について一メタデータ協調の視点から一

久保 誠 133

\section{メディア教育研究 第3巻 第2号 通巻第6号 平成19年(2007年) 3月}

特集 : e-Learningにおける高等教育機関の質保証への取り組み

e ラーニングにおける多様なデータを活用した質保証と評価のフレームワーク（青山学院大学） 松田 岳士・合田 美子・玉木 欽也 1

e-Learning を用いた社会人遠隔学習における質保証への取組一学生サポートの実践と評価 一 (信州大学)

不破 泰・右代 美香・國宗 永佳・新村 正明 13 e ラーニング専門家養成のための e ラーニング大学院における質保証への取組 :

熊本大学大学院教授システム学専攻の事例

北村 士朗・鈴木 克明・中野 裕司・宇佐川 毅・大森不二雄・入口 紀男

喜多 敏博・江川 良裕・高橋幸・根本 淳子・松葉 龍一・右田 雅裕 25

e-Learning における質保証一早稲田大学人間科学部 e スクールの取組一 西村 昭治 37 海外の高等教育における e ラーニングの質保証の展開—2006 年 NIME 国際シンポジウムから一 (NIME)

篠原 正典・山村 弘・清水 康敬 45

原著論文

ソフトウェア開発グループ演習のためのチーム編成の最適化支援

橋浦 弘明・桑原 徹・秋 玉梅・石川 達也・山下公太郎・古宮 誠一 61 
研究資料

小・中学生のメディアリテラシーに関する一考察

向田久美子・坂元 章・一色 伸夫・森 津太子・鈴木 佳苗

駒谷 真美・佐渡真紀子 71

e ラーニングコンテンツの制作と多分野での利用について

穗屋下 茂・角 和博・江原 由裕・米満 潔・藤井 俊子・ 久家 淳子

池上 仁・池田 絵美・梶原しおり・朴 逸子・時井 由花・古賀 崇朗

梅崎 卓哉・近藤 弘樹 85

e ラーニングを活用した工学教育環境の構築

穗屋下 茂・田代 雅美・藤井 俊子・米満 潔・梅崎 卓哉 95 学部教育プログラムでの e-Learning 活用に基づく教育デザインの実証研究

川西雪也・林 康弘・高岡 詠子・碓井 広義・山川 広人・小松川 浩 105 歯学部病理診断学における Web 教材の活用と学習効果の検証

青葉 孝昭・佐藤かおり・柬理 頼亮 115

Class Research on Learning Methods in Movie-based Computer Assisted Language Learning

Junko Yamamoto $\cdot$ Takaaki Okura Yoko Watanabe 125

研究開発速報

テキストの継時処理訓練が英語リスニング能力の向上に与える影響４ 小山 義徳 137

$\mathrm{JAD}$ プログラムにおける日本語学習進渉状況共有システムの提案及びその実装方法

八重樫理人・佐々木良造・石松 純・尾沼 玄也・山下 哲生

橘雅彦・小林 孝郎 143

\section{メディア教育研究 第 4 巻 第 1 号 通巻第 7 号 平成19年(2007年) 9 月}

特集「FD (ファカルティ・ディベロップメント)一大学教員の教育方法の改善への取り組み一」

ICT 活用による FD の現状と NIME の取り組み（NIME）

FD 制度化の現状と展望（比治山大学）

清水 康敬 1

有本章 9

大学教員の教育力強化とメディア活用一アメリカの事例分析とその含意一（NIME）

大学教育の質を総合的に向上させる研修教材の評価（名古屋大学）

苑 復傑・清水 康敬 19

中井 俊樹 ・齋藤 芳子 31

京都大学における ICT を活用した FD 実践の取り組み一「遠隔連携ゼミ」と「Web 公開授業」一

FD 推進機関における 2 つの機能（NIME）

酒井 博之 41

田口 真奈 53

原著論文

博物館におけるデジタル画像の教育普及活用の実情と課題一ICT 機能を活用した博物館学習 支援の可能性一

奥本 素子・加藤 $\quad$ 浩 65

展望論文

学習者間の相互評価に関する研究の動向と課題

藤原 康宏・大西 仁・加藤 浩 77 


\section{独立行政法人メディア教育開発センター研究成果刊行物}

\begin{tabular}{|c|l|}
\hline メディア教育研究 & $\begin{array}{l}\text { 多様なメディアを利用して行う教育の研究及び開発に } \\
\text { 関する動向、展望及び学術研究の成果（論文、研究資 } \\
\text { 料、研究展望の区分）を掲載する。 }\end{array}$ \\
\hline N I ME研究報告 & $\begin{array}{l}\text { センターにおける研究調查、研究開発の成果及びシン } \\
\text { ポジウムの記録等の研究及び活動報告を掲載する。 }\end{array}$ \\
\hline
\end{tabular}

\section{NIME研究報告第40号 \\ ISSN $\quad 1880-2192$}

平成 20 年 3 月 14 日

発行者 独立行政法人

メディア教育開発センター

干261-0014 千葉市美浜区若葉2丁目12番地

TEL 043-276-1111（代表）

印刷者 株カントー 